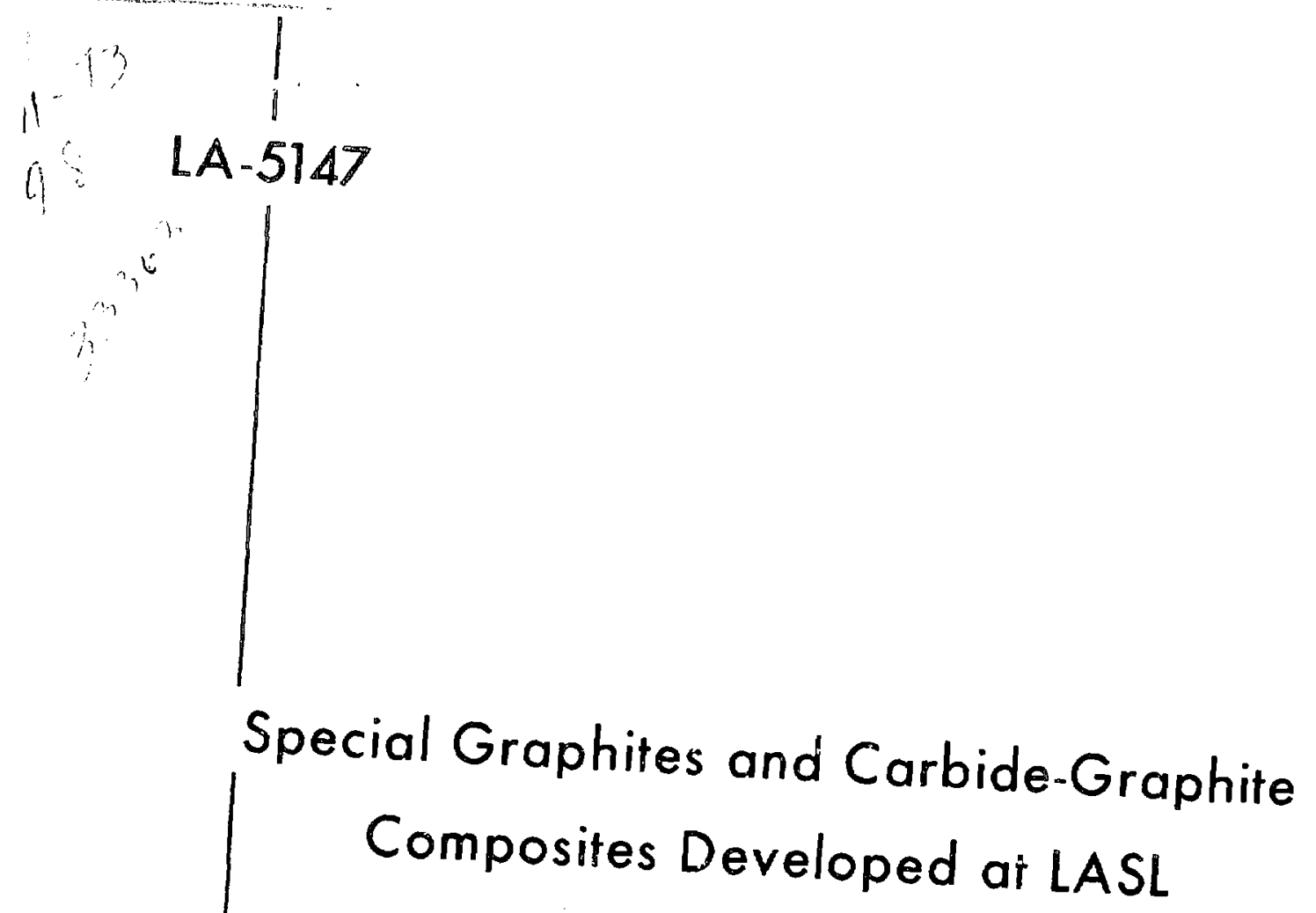

THIS DOCUMENT CONFIRMED AS UNCLASSIFIED

DIVISION OF CLASSIFICATION

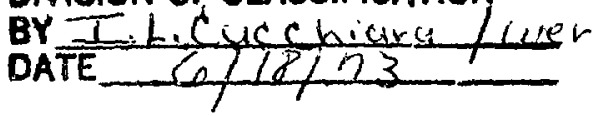
LOS ALAMOS, NEW MEXICO B7544

$i$ 
This report was prepared as an account of work sponsored by the United States Government. Neither the Linited States nor the United States Atomic Energy Commission, nor any of their employees, nor any oi their contrac. tors, subcontractors, or their employees, makes any warranty, express or im. plied, or assumes any legal liability or responsibility for the accuracy, com. pleteness or usefulness of any information, appuratus, product or process dis. closed, or represents that its use would not inffinge privately owned rights.

Printed in the United States of America. Available from National Technical Information Service

U. S. Department of Commerce 5285 Port Royal Road Springfiels, Virginio 22151

Price: Printed Copy Sted; Microfiche $\$ 0.95$

$$
5,45
$$




\title{
Special Graphites and Carbide-Graphite Composites Developed af LASL
}

\author{
by
}

R. E. Riley

This report supnrsedes LA.3509-MS, LA-3618-MS, LA-3652-MS, and LA.4077.

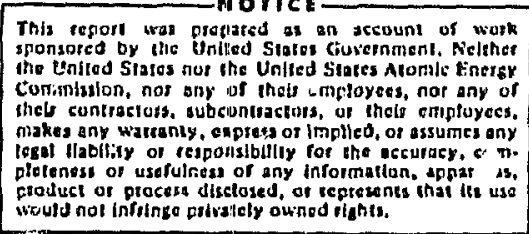


SPECIAS GRAPHITES AND CAPBIDE-GRAPHITE COAPOSIIFS IEVELOFED A' LASL

by

R. E. Riley

\section{ABSTRACT}

Hell-chartcterized naterisis containing either TeC and graphite or pure grephite vere fabrs cated utilizing porder metallurby techniques that included hot pressing or hydrostatic pressing end subsequent hightemperature heat treatment. Fhysical structure and therwal properties vere investigated, particularly themel-streso fracture resistence. He found that vell-controlled reproducible materials canifesting an excellent diptribution of carbide in the Eraphite antrix could be fabricated willzing elther technique. Thermal properties were affected olgnincantly by the alze and relative amounts of TeC and graphite used in the composite. Data on dynerite elastic modulus, therad expansion, thermal conductivity, and thereal-stress racture reslotance are presented.

\section{x. Dersoduction}

A continuing interest in carbide-graphl te cowpont tee prevalio ot the los Almos Selentific Lobora20ry (LSIs) of the tiniversity of Califorida due to the userul characteristics of these materials under extrese teperature conditiona. The tantalum carbidebrophite oystem has evoked particuzar interest due to the extrenely high welting point of TaC $\left(3900^{\circ} \mathrm{C}\right)$ and the hab Tac-c eutectic temperature of $3720^{\circ} \mathrm{C}$. Previoul work ${ }^{2-4}$ by the LAST Kiterial Technology Group (atb-6) has provided ineight into the erfect of procesolng vartables, carblite pouder characteristics, composition, binder content, and graphite particlo characterlet1ce upon the phyacel and mechanicel properties of hot-preased carblde-graghite coupostes In geperal, and upon Tac-c composites in particurer.

The pupose of this investigation was to devilop an altermative procese to hot presaing for the production of rac-C composite material, and to deteraine and compare aelected properties of mter1ala prepured in each manner. A procedure for hydrostatically preasing and absequentiy heat treating coupacts of Tac and grophite vas doveloped, and varlous techniques vere utilized to erainte the material protduced in the manner and by hot proasing. Mlao, three different aize ranges of graphlte vare hydrom ataticaly preased and tested ror nuture reforence and possible spplicability to carbide-graphste oyeters. The evaluetsons of phyescal structure and therand properties, particularly therwal-shock capebilities, were of most interest during this in investigation. Particusar attention vas pald to the orfect of carblde content and carblde particle 012 .

\section{WTERTAIS}

The ray atterials wed in the Investigation compleed several 2ots of TaC, one of Noc, three alie ranges of graphte, and Varcum binder.

\section{A. Tantulu Carbide (Tac) Pouders}

Analyses and characteriotice of the TaC poider used are presented in Trbles I and II, respectively. Ftre of the poudera uaed are shown in the ghotom. cropreghe of 7ga. 1 through 5. Bcandios electron microdxaphs of the nominel $300-\lambda$ TaC (TeC-38) povder are thown in Fga. 6 through 8 .

\section{B. Nloblum Carbide (FoC) Powdex}

The Boc powder, Lot Noc-43, was purchased from Wha chane Chemical compeny. This powder lot hed a Finher average particle o1ze (APO) of $3.51 \mathrm{\mu m}$, a burk dentrity of $2.62 \mathrm{~s} / \mathrm{cm}^{3}$, a tep denalty of 3.82 $6 / \mathrm{Cr}^{3}$, and apectric aurface ares meanurente of 0.229 and 1.205 a/6 sor Fuher and als aternsintlon, reopectivaly. Chosical analyole rovealeć 88.4\% nloblua, 21.35 tota carbon, 0.335 frea curbon, 
TABLE I

CHFMICAL ANALYSES OF TEC POWLER IOTS ${ }^{8}$

\begin{tabular}{|c|c|c|c|c|c|c|c|c|}
\hline Elements & TeC-11 & Tac-25 & Tac-29 & TaC-30 & $\mathrm{TeC}-32$ & Tec-33 & TaC-38 & $\mathrm{TeC}-45$ \\
\hline $\mathrm{Ta}$ & 93.38 & $92.9 \$$ & $93.44 \%$ & $93.81 \%$ & $93.34 \%$ & $92.0 \%$ & $90.8 \%$ & $93.6 \%$ \\
\hline Total c & $6.25 \%$ & $6.70 \%$ & $5.98 \%$ & $6.10 \%$ & $6.30 \%$ & $6.30 \%$ & $7.30 \%$ & $6.20 \%$ \\
\hline Eree C & $0.08 \%$ & $0.65 \%$ & $<500$ & 790 & 780 & $0.50 \%$ & $1.70 \%$ & $0.10 \%$ \\
\hline$o_{2}$ & $0.21 \%$ & 570 & 0.198 & $0.18 \%$ & $0.17 \%$ & $1.40 \%$ & $1.70 \%$ & 580 \\
\hline $\mathbf{H}$ & $<1$ & $<3$ & $<1$ & $<3$ & $<1$ & $<3$ & $<1$ & $<1$ \\
\hline $\mathrm{Be}$ & $<1$ & $<1$ & $<1$ & $<1$ & $<1$ & $<1$ & $<1$ & $<1$ \\
\hline $\mathbf{B}$ & 3 & $<3$ & $<3$ & $<3$ & $<3$ & $<3$ & $<3$ & $<3$ \\
\hline Ne & $<3$ & $<3$ & $<3$ & $<3$ & $<3$ & $<3$ & $<3$ & $<3$ \\
\hline $\mathrm{KB}$ & 3 & 1 & 15 & 15 & $<1$ & 2 & 20 & $<1$ \\
\hline Al & $<3$ & $<3$ & 5 & 3 & 10 & $<3$ & 15 & 10 \\
\hline BI & 100 & 5 & 10 & 5 & 5 & 10 & 15 & 10 \\
\hline $\mathbf{K}$ & $<30$ & $<30$ & $<10$ & $<10$ & $<10$ & $<30$ & $<10$ & $<10$ \\
\hline $\mathrm{Ca}$ & 3 & 3 & 3 & 2 & 5 & 3 & 2 & 3 \\
\hline $\mathrm{T} 1$ & $<5$ & $<5$ & $<5$ & $<5$ & 150 & 10 & 10 & 50 \\
\hline $\mathbf{V}$ & $<10$ & $<10$ & $<10$ & $<10$ & $<10$ & 20 & $<10$ & $<10$ \\
\hline$C r$ & 5 & 5 & 10 & 10 & $0.1 \%$ & 300 & 600 & 300 \\
\hline Mn & 1 & $<1$ & 2 & $<1$ & 2 & 10 & 10 & 3 \\
\hline $\mathrm{Fe}$ & 200 & 50 & 150 & 150 & 50 & 300 & 800 & 500 \\
\hline co & $<5$ & $<5$ & $<5$ & $<5$ & 200 & $<5$ & $<5$ & $2 \infty$ \\
\hline NA & 1 & 20 & $<5$ & 2 & 30 & 100 & 0.18 & 300 \\
\hline Gu & 30 & $<1$ & 2 & 2 & 8 & 15 & 10 & $<1$ \\
\hline$Z_{n}$ & $<100$ & $<100$ & $<100$ & $<100$ & $<100$ & $<100$ & $<100$ & $<100$ \\
\hline $\mathbf{B r}$ & $<30$ & $<30$ & $<30$ & $<30$ & $<30$ & $<30$ & $<30$ & $<30$ \\
\hline $\mathbf{Y}$ & $<30$ & $<30$ & $<30$ & $<30$ & $<30$ & $<30$ & $<30$ & $<30$ \\
\hline $\mathbf{2 r}$ & $<30$ & $<30$ & $<30$ & $<30$ & $<30$ & $<30$ & $<30$ & $<30$ \\
\hline $\mathrm{Nb}$ & 0.18 & 0.38 & 500 & 200 & 0.24 & $2 \infty 0$ & 0.756 & 300 \\
\hline Ho & $<10$ & $<10$ & $<10$ & $<10$ & 50 & 10 & $<10$ & $<100$ \\
\hline$A B$ & $<1$ & $<1$ & 3 & $<1$ & $<1$ & $<1$ & $<1$ & $<1$ \\
\hline 8n & $<3$ & $<3$ & $<3$ & $<3$ & $<3$ & $<3$ & $<3$ & $<3$ \\
\hline Ba & $<10$ & $<10$ & $<10$ & $<10$ & $<10$ & $<10$ & $<10$ & $<10$ \\
\hline$W$ & $<30$ & $<30$ & $<30$ & $<30$ & 0.34 & 200 & 50 & $<30$ \\
\hline $\mathbf{P b}$ & $<3$ & $<3$ & $<3$ & 30 & $<3$ & $<3$ & $<3$ & $<3$ \\
\hline BI & $<5$ & $<5$ & $<5$ & $<5$ & $<5$ & $<5$ & $<5$ & $<5$ \\
\hline
\end{tabular}

$a_{A l l}$ values are poin unlegs otinervise indicated. 
TABLE II

TAC MUARACTERIZATION IRTA

\begin{tabular}{|c|c|c|c|c|c|c|}
\hline \multirow[b]{2}{*}{$\begin{array}{l}\text { Powder } \\
\text { Lot }\end{array}$} & \multirow[b]{2}{*}{ Supplier } & \multicolumn{2}{|c|}{ Deno1ty } & \multirow{2}{*}{$\begin{array}{l}\text { Flaher } \\
\text { APS } \\
\text { (iㅣ }\end{array}$} & \multicolumn{2}{|c|}{$\begin{array}{r}\text { Epec1fic } \\
\text { Surface }\end{array}$} \\
\hline & & $\begin{array}{l}\mathrm{Bu} x \\
\left(\mathrm{~B} / \mathrm{cm}^{3}\right)\end{array}$ & $\begin{array}{c}\left.\operatorname{Tap}^{3} / \mathrm{con}^{3}\right) \\
\end{array}$ & & $\left(\mathrm{E}^{2} / \mathrm{B}\right)$ & $\begin{array}{l}\text { 7oher } \\
\left(\mathrm{u}^{2} / \mathrm{B}\right)\end{array}$ \\
\hline TaC-11 & Feribar & 6.04 & 0.01 & 4.2 & 0.616 & 0.098 \\
\hline Tac-15 & Union Carbide & 1.90 & 3.20 & 0.13 & 3.22 & \\
\hline Tac-29 & Kavecin1 & 4.59 & 6.31 & 1.30 & $i .305$ & 0.325 \\
\hline $2 a c-30$ & Kareck1 & 4.51 & 6.42 & 1.37 & 2.109 & 0.299 \\
\hline rac-32 & Starck & 5.13 & 8.00 & 1.85 & 0.712 & 0.410 \\
\hline $\mathrm{TaC}-33$ & ciba & - & - & $300 k$ & 17.524 & - \\
\hline $\operatorname{Tac}-38$ & Starel & $-\infty$ & $=$ & $300 \mathrm{~L}$ & 41,614 & - \\
\hline $\mathrm{Tac}-45$ & Aterck & 5.24 & 6.61 & 8.6 & 0.498 & $0.04 \theta$ \\
\hline
\end{tabular}

and $0.31 \%$ oxygen. Th1s material was used in $50 / 50$ wto solid solution with TaC, and was included for comparison purposes.

\section{c. Graphite Flours}

1. M-3 Graphite Flour. The graphite flour used in this progran was Grade 1008, supplied by Great Lakes Carbon Company, and was given the IASL Identifying number $M-3$. Typscal chemical analyses and size distribution of the as-received flour are presented in Tables III and IV, respectively. The bulk of the graphite used in this examination wes the -325 fraction of the $\mathrm{M}-3$ flour, wh1ch was the portion used in the carblde-grephite composite material and as one of the siae ranges used for 1nvest1gation of pure graphite materials. Pure graphite specimens used were the $-150+325$ mesh fraction and a standard a1x composed of $85 \%$ (by welght) $M-3$ flour and $15 \%$ Thermax.

2. 8-97 Graphite Flour. The second grapht te used, abtalned from speer Carbon fompany, was debignated 5-97. The chenlcal analyses of this flour and the particle size dintribution are given in Tables III and IV, respectively.

D. Thermax

Thermax is a carbon black of $0.9-\mu$ average particle slze obtained from thermatomic carbon co..

TARIE III

CHEYICAL ARALYSES OF GRAFHIIE FLOURS

\begin{tabular}{|c|c|c|}
\hline Impurity $^{\mathrm{a}}$ & $\begin{array}{l}\mathrm{H}-3 \text { Four } \\
\text { (pon) }\end{array}$ & $\begin{array}{l}\text { 6-97 FLour } \\
\text { (pas) }\end{array}$ \\
\hline Abh & 300 & 200 \\
\hline Iron & 100 & 70 \\
\hline silicon & 150 & 30 \\
\hline
\end{tabular}

A.11 others 1 ess than 200 ppon total.
TABLE IV

PAFIICLE SIZE DISTRIBUTION OF GRAPHITE FLOURS

\begin{tabular}{ccc} 
Mesh Size & $\begin{array}{c}\text { M-3 Fiour } \\
(\mathrm{Ht})\end{array}$ & $\begin{array}{c}\text { S-97 Four } \\
(\mathrm{Wt})\end{array}$ \\
\cline { 2 - 3 }+65 & 3 & 0 \\
$-65+100$ & 5 & 0 \\
$-100+150$ & 11 & 0 \\
$-150+200$ & 26 & 0 \\
$-200+270$ & 10 & 10 \\
$-270+325$ & 15 & 20 \\
-325 & 30 & 70
\end{tabular}

The chemical analyses of this naterial are shown in Table V.

\section{E. Varcum Binder}

When a binder was naeded, we used Varcum 8251, a thertosetting reain of partially polymerized turfuryl alcohol obtained from the Varcum Chemical D1violon of Reichhold Chemicals, Inc. Malelc anhydride was used as a catalyst in the amount of $4 \mathrm{~g}$ per $100 \mathrm{~cm}^{3}$ of resin. The viscosity of this material at room temperature is about $300 \mathrm{cP}$, and decreases rapidily to about $50 \mathrm{cP}$ at $50^{\circ} \mathrm{C}$.

\section{EQUIFAIENT}

\section{A. Blenders}

A Patterson-Kelly 8- or 16-qt twin shell blender equipped with an intensifler bar and Ilquid adaltion apparatus was used for dry ingredient wixing and liquid binder addition. The 16-qt blender 18 shown in Fig. 9. For the hot-pressing blends with

TABLE V

CHIJICAL ANALYSES OF THERWAX

\begin{tabular}{|c|c|}
\hline Iupur 1ty $^{a}$ & Amount (pow) \\
\hline A日h & $700-2000$ \\
\hline 81 & $100-620$ \\
\hline $\mathrm{Fe}$ & $30-$ \\
\hline ca & 10 \\
\hline $\mathrm{Hg}$ & s- \\
\hline $\mathrm{Na}$ & $5-$ \\
\hline Al & $3-$ \\
\hline $\operatorname{Mn}$ & $1-$ \\
\hline
\end{tabular}

All other alements below detection limit. of spectrochemical analye1s. 
no binder, mixing was done in glass jars contalning aluminum agitator wires.

\section{B. Homogentzer}

A Hobart Model 4532 meat chopper equipped with a breaker plate with 1/8-in.-diam holes was used for homogenizing and precompacting the hydrostatic pressing mixes (Fig. 10).

C. Pressings Sacks

The pressing sacks and lids were furnished by the IASL Plastics Section of Group CMB-6 and were made of Plastiscl. These sacks were formed by dipping a mendrel into Plastisol and curing at $175^{\circ} \mathrm{C}$ for $45 \mathrm{~min}$.

\section{Hydrostatic Press}

The loaded pressing sacks were pressed by hydrostatic pressure of 30,000 psi in a 12-in.-i.d. by 24in.-long chamber utilizing oil pressurized by an air operated pump (FIg. 11).

\section{E. Curing oven}

The hydrostatically pressed pleces were cured in en oven capeble of maintelining the rigid timetemperature schedule outlined in section IV. F. The unlt used was an eiectrically heated circulating alr oven capable of sustained operation at up to $450^{\circ} \mathrm{C}$. The oven, Nodel Fo 962430, was made by the Cooley Electrical Manufacturing Company, anc was controlled by a cam-operated wheelco Instrument Company controller. The oven, along with the containers that held the pressings, is shown in Fig. 12.

\section{F. Baking Furnace}

The cured pleces were baked under vacuum to $800^{\circ} \mathrm{C}$ as inalcated in Section IV. G. The pleces were placed inside a stainless steel can and were baked in a furnace designed and built at IASL. The furnace was heated by resistance heating elements controlled by a cam-operated wheelco controller. The hot zone of the furnace was $16 \mathrm{in}$. dlam by 60 in. long; the furnace normally operated under a pressure of 10 torr or less. The vacuun system consisted of a two-stage Nesh Hytor pump: two Model TS-10 pumps connected in series, but powered by a single 10-hp electrlc motor. An al.r-operated valve In the vacuum line prevented afr from being drawn ints the furnace through the vacuum pump in case of a yower fallure. Also, a belf-opening trap prevented the vacuum pump water from entering the furnece. The baking furnace is shown in Flg. 13.

\section{G. Sintering Furnace}

Following baking, the pleces not to be hot pressed were heat treated to $2500^{\circ} \mathrm{C}$ according to the schedule described in Section IV. H. They were placed in a graphite crucible and sincered in an induction heated furnace designed and built at LASL. The Induction coil was powered by a 175-kW 960-cycla motor generator set. The 82-1n.-long coil consisted of flat 6-in.-wide copper strips bent and sil.versolaered together to form a cylinder. Three parallel copper cubes to carry cooling water were silversoldered to the outside of the coll. The crucible containing the pressings was located within a graph1te susceptor, 18.75-in.-0.d. by 16.62-1n.-1.d. The susceptor, in turn, was surrounded by a 3-in.-thick layer of carbon black insulation, a 1-1n.-thick ceramic liner, a layer of Fiberfrax, and the induction coil. The temperature in the furnace was measured optically through a sight port in the top of the furnace that sighted into a hole in the graphite crucible. A helium flush kept the sight port open and prevented the graphite in the furnace from oxidizing. The induction furnace is shown in Fig. 14. H. H1gh-Temperature Sintering Furnace

Following sintering, some of the pieces were subjected to a higher temperature heat treatment similar to that described in section IV. I. The furnace used for this purpose was capable of operating at $3000^{\circ} \mathrm{C}$ for a sustained period. The pieces produced at IASI were heat treated in graphite cruclbles In an induction furnace (Fig. 15) dersigned and built at LASL. The coil was a self-shlelded, light-tight, current-concentrating coll poirered by a 150-kW 10,000-cycle motor generator set. Temperature was measured by sighting through a hole in the crucible lid directly on the piece. An argon flush kept the sight poxt open and prevented oxidation.

\section{Hut-Press Furnaces}

The hot-press Adinesces used (Fig. 16) were of the induction heated wye shown in Fig. 17.

\section{PROCEDURE}

\section{A. Preparation of Materials}

Before use, the graphlte and carblde powders were screened through a 150-mesh screen to ensure against introduction of forelgn particles. Also, they were dried for $24 \mathrm{~h}$ at $150^{\circ} \mathrm{C}$ to minimize 
the presence of water vapor and to help prevent agglomeration. The binder resin was stored in 55-gal drums. The drums to be used were then rolled in the storage area at $400 \mathrm{rpm}$ for $2 \mathrm{~h}$ to homogenize the material before withdrawal. The quantity of resin required for a day's work was withdrawn from the drim the evening before use and was placed overnight in an oven at $35^{\circ} \mathrm{C}$. The malelc anhydride catalyst was ground and screened to -20 mesh prior to use, and $4 \mathrm{~g}$ of catalyst per $100 \mathrm{~cm}^{3}$ of resin was added to the original resin. The mixing was performed in 1-gal batches; the $\mathrm{mix}$ was heated to $40^{\circ} \mathrm{C}$ and stirred for axproximately $20 \mathrm{~min}$ before use. Maleic anhydride is a slow-acting catalyst at $40^{\circ} \mathrm{C}$ so the processing times were not critical.

B. Blending

The dry ingredients (graphite, or graphite and

$\mathrm{TaC}$ ) for the 8-at Paterson-Kelly blender were in the range of 1 to $4 \mathrm{~kg}$ to ensure good blending. The dry ingredients for a $\mathrm{ml} x$ were weighed and placed in the blender: the TaC first and the graphite last. They were $d r y$ blended for 30 min using the Intensifier bar. The proper amount of catalyzed resin was weighed and placed in a glass reservoir wound with a heatIng tape. The reservoir had a tube leading to the liquid addition apparatus of the Patterson-Kelly blender. The resin, after heating to approximately $40^{\circ} \mathrm{C}$, was added slowly under 3-psi alr pressure to the $\mathrm{dry} \mathrm{mix}$ over a period of 15 to $20 \mathrm{~min}$ through the intensifier bar of the blender. After the resin addition was completed, the blender was stopped, the lids opened, and the lids and blender walls were scraped to remove adhering material. The blender was then sealed and rotated for another $5 \mathrm{~min}$ with the intensifier bar operating. The blended material had the colisistency of molst sand.

\section{c. Homogenization}

The blende containing no binder went directly to the screening step, but the ones containing Varcum underwent the following homogenization, probably the most Imporiant single step for ensuring the homogeneity and distribution desired in the final product. A Hobart meat chopper was used to homogenize the $\mathrm{mix}$, which was passed through the meat chopper six times before belng losded into the pressing backs. Normally the meat chopper is fltte ${ }^{2}$ with a chopper plate having 3/16-in.-diam hole日. A p.late with 1/8-In.-diam holes, however, was used for these mixes to improve the mixing and homogenization obtalned.

D. Screening

Following the homogenization operation, the $\mathrm{mix}$ was forced through a 20-mesh screen to break up large clusters ani to give the mix better flow properties for loading into the pressing sacks.

\section{E. Hyarostatic Pressing}

The parts comprising a pressing sack (F1g, 18) Included the sack and lid, clamping ring, Aero seal clamp, hypodermic needle, sponge, and ritx. The pressing sacks were filled with the loose screened mix, and the mix was packed lightly by tapping the filled sacks. More loose material was then added, and the procedure was repeated several times until no compaction was noteá. The sack $11 d$ was pierced with a No. 16 hypodermic needle with a $7 / 8$-in.-diam by $1 / 2-i n .-t h i c k$ sponge affixed to the needle point. A clamping ring was then placed around the inner diameter of the lid and the lid seated in the sack. The sack was sealed with an Aero Seal hose clamp and a sealing solution described below. The sack and its contents were then evacuated through the protruding hypodermic needle, usually for $1 / 2 \mathrm{~h}$ (Flg. 19). The needle was extracted from the $11 d$ and the hole sealed with a solution of poly-vinyl-chloride in equal parts of methyl, ethyl, ketone, and acetone. The loaded and evacuated sacks were then placed in the pressure chamber, oil added, and the chamber closed. The atr-operated oil purp was started, end the chamber was pressurized to the required pressire. The pressure vas immediately released and the chamber. opened. Dil was removed from the enterior of the sacks with hexane before they were opened.

F. curing

The green pressings were eured according to the time-temperature schedule shown in Table VI. Curing resulted in the polymerization of the thermosetting binder. This process occurred in an atr atmosphere; the pleces were merely wrapped in aluminum foil and placed inside the oven. The $1{ }^{\circ} \mathrm{C} / \mathrm{h}$ rate was very $1 \mathrm{it}-$ portant in the range where volatiles from polymerization were being released.

\section{G. Baking}

The cured pressings were then baked under vacuum according to the schedule given in Table VI to carbonize the binder and further remove gases and volatiles. Baking was done Inside a stalnless steel can with a loose-fltting lid. 
TABLE VI

TIME AND TEMPERATUFE SCHEDULES FOR CURING AND BAKTIG

\begin{tabular}{|c|c|c|c|c|}
\hline \multirow[b]{2}{*}{$\begin{array}{l}\text { Time } \\
\text { (h) }\end{array}$} & \multicolumn{2}{|c|}{ Gure } & \multicolumn{2}{|c|}{ Bake } \\
\hline & $\begin{array}{l}\text { Temp } \\
\left({ }^{\circ} \mathrm{C}\right)\end{array}$ & $\begin{array}{l}\text { Rete } \\
\left({ }^{\circ} \mathrm{C}\right)\end{array}$ & $\begin{array}{l}\text { Temp } \\
\left({ }^{\circ} \mathrm{C}\right)\end{array}$ & $\begin{array}{l}\text { Rate } \\
\left({ }^{\circ} \mathrm{C}\right)\end{array}$ \\
\hline 3 & 53 & 1 & 250 & 10 \\
\hline 6 & 56 & 1 & 280 & 10 \\
\hline 9 & 59 & 1 & 310 & 10 \\
\hline 12 & 62 & 1 & 340 & 10 \\
\hline 15 & 65 & 1 & 370 & 10 \\
\hline 18 & 68 & $I$ & 400 & 10 \\
\hline 21 & $\pi$ & 1 & 430 & 10 \\
\hline 24 & 74 & 1 & 460 & 10 \\
\hline 27 & $T 7$ & 1 & 490 & 10 \\
\hline 30 & 80 & 1 & 520 & 10 \\
\hline 33 & 83 & 1 & 550 & 10 \\
\hline 36 & 86 & 1 & 580 & 10 \\
\hline 39 & 89 & 1 & 610 & 10 \\
\hline 42 & 92 & 1 & 685 & 25 \\
\hline 45 & 95 & 1 & 760 & 25 \\
\hline 48 & 98 & 1 & 835 & 25 \\
\hline 51 & 101 & 1 & & \\
\hline 54 & 104 & 1 & & \\
\hline 57 & 107 & 1 & & \\
\hline 60 & 110 & 1 & & \\
\hline 62 & 112 & 1 & & \\
\hline 65 & 3.18 & 2 & & \\
\hline 68 & 124 & 2 & & \\
\hline 71 & 130 & 2 & & \\
\hline 74 & 142 & 4 & & \\
\hline 77 & 160 & 6 & & \\
\hline 80 & 180 & $6-2 / 3$ & & \\
\hline 83 & 200 & $6-2 / 3$ & & \\
\hline 86 & 225 & $8-1 / 3$ & & \\
\hline 89 & 250 & $8-1 / 3$ & & \\
\hline
\end{tabular}

Following this step the pleces to be hot pressed vere advanced to the hot-pressing step described In Section IV. J.

\section{H. Sintering}

A sintering run to $2500^{\circ} \mathrm{C}$ followed the baking cycle. The baked preseings were placed in a graphlte crucible that, in turn, was placed in the induction heated sintering furnace. The pressings were heated to $2500^{\circ} \mathrm{C}$ over $4-1 / 2 \mathrm{~h}$ and held at terperature for $2 \mathrm{~h}$. A helium atmosphere was maintained in the furnace during this period and during the 1-1/2-day cooling cycle. Heat treatment of the pure rsraphite pleces ended here. All pleces undergoing sintering were machined to right cylinders following this step.

I. High-Temperature Heat Treatment

Following the sintering cycle, the pressings containing TaC and graphite were heat treated at $3000^{\circ} \mathrm{C}$ for $1 \mathrm{~h}$. The pieces were heated rapidly to $3000^{\circ} \mathrm{C}$ using a $40-m i n$ ramp. An argon atmosphere protected the pieces from oxidation.

J. Hot Pressing

The hot-pressed pleces underwent this process following the baking step. The hot-pressing schedule employed was as follows: aster the die was loaded, positioned in the induction coil, and flushed with argon, it was heated to $3050^{\circ} \mathrm{C}$ in $40 \mathrm{~min}$ while a pressure of 3200 psi was gradually applied. Pressure was maintained for cioout 30 to $40 \mathrm{~min}$, followIng which the power wes shut off and the die allowed to cool. Pressure was not released unt1l the temperature fell below $2000^{\circ} \mathrm{C}$.

\section{v. COMPOSIIIONS}

A. TaC-Graphite

The varlous compositions Investigated are given In Table VII. A 50\% coking value was used in batch calculations to Indicate the Varcum contribution to the carbon content. Varcum demends varied depenaing on the percentage of carbide in the mix and the particle size of the carbide used. The requirements ranged from 20 to $23 \%$ of the dry ingredient welght. Binder demands might vary considerably from this figure if the particle size of the graphite used were to be changed.

TABLE VII

TaC GRAPHITE COMPOSITIONS

\begin{tabular}{|c|c|c|c|c|c|c|}
\hline 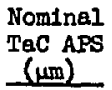 & $\begin{array}{c}1 \\
\text { Wtक } \\
\end{array}$ & $\begin{array}{r}5 \\
\text { wts }\end{array}$ & ${ }_{\text {Wts }}^{7}$ & $\begin{array}{l}14 \\
1 t \phi\end{array}$ & $\begin{array}{l}20 \\
\text { Wts }\end{array}$ & $\begin{array}{r}40 \\
\text { wt\% } \\
\end{array}$ \\
\hline 40.0 & $\mathbf{s}$ & $\mathbf{s}$ & $\mathbf{S}$ & $\mathbf{S}$ & $S$ & $\mathbf{S}$ \\
\hline 4.2 & & & & & & $\mathrm{H}$ \\
\hline 1.3 & $\mathbf{s}$ & $\mathbf{s}$ & $\mathbf{s}$ & $\mathbf{s}$ & & $\mathbf{S}, \mathrm{H}$ \\
\hline 0.13 & & & & & & H \\
\hline $300 \&$ & $\mathbf{S}$ & $s$ & $\mathbf{s}$ & $\mathbf{S}$ & $\mathbf{S}$ & H \\
\hline
\end{tabular}

S - hydrostat1cally pressed and sintered; He-hot pressed. 
TABLE VIII

SAMPLE DESCRIPTIONS

\begin{tabular}{|c|c|c|c|c|c|c|}
\hline $\begin{array}{l}\text { Semple } \\
\text { No. } \\
\end{array}$ & $\begin{array}{c}\text { Wty } \\
\text { Carbide } \\
\end{array}$ & $\begin{array}{l}\text { TaC Particle } \\
\text { Size } \\
\end{array}$ & $\begin{array}{c}\text { Graphite Size } \\
\text { and Source }\end{array}$ & $\begin{array}{l}\text { Fabrication } \\
\text { Technique }\end{array}$ & $\begin{array}{l}\text { Density } \\
\left(\mathrm{B}\left(\mathrm{cm}^{3}\right)\right.\end{array}$ & $\begin{array}{l}\text { o Theo } \\
\text { Density }\end{array}$ \\
\hline $2111 \mathrm{~A}$ & 40 & $0.13 \mu \mathrm{m}$ & $-325 M-3$ & Hot Pressed & 2.65 & 78.0 \\
\hline $2108 \mathrm{~A}$ & 40 & $4.2 \mu \mathrm{m}$ & $-325 \mathrm{M}-3$ & Hot Pressed & 2.66 & 78.3 \\
\hline $2106 \mathrm{~A}$ & 40 & $300 \AA$ & $-325 x-3$ & Hot Pressed & 2.65 & 78.0 \\
\hline $2141 \mathrm{~A}$ & 40 & $1.3 \mu \mathrm{m}$ & $-325 \mathrm{M}-3$ & Hot Pressed & 2.74 & 80.6 \\
\hline$S-4006 D^{c}$ & 10 vol\% & $\begin{array}{l}\mathrm{NbC} 3.5 \mathrm{\mu m}, \\
\mathrm{TaC} 1.65 \mathrm{\mu m}\end{array}$ & $-150+325 \mathrm{M}-j$ & Hot Pressed & 2.71 & 82.9 \\
\hline 101 & 40 & $300 \AA$ & $-325 \mathrm{M}-3$ & Sintered & 2.54 & 74.7 \\
\hline 102 & 40 & $1.3 \mu \mathrm{m}$ & $-325 M-3$ & Sintered & 2.47 & 72.7 \\
\hline 0924 & None & None & -200 mesh $5-97$ & Sintered & 1.825 & 81.1 \\
\hline $\mathrm{E}-001$ & None & None & $\begin{array}{l}85 \text { wt\% M-3, } \\
15 \text { wt } \text { Thermex }\end{array}$ & $\begin{array}{l}\text { Extruded } \\
\text { and Sintered }\end{array}$ & 1.875 & 83.3 \\
\hline $0941-4$ & None & None & $-325 \mathrm{M}-3+$ Varcum & Sintered & 1.46 & 64.9 \\
\hline $0941-16$ & None & None & $\begin{array}{l}85 \text { wt } \% \text { - } 325 \mathrm{M}-3 \text {, } \\
15 \text { wt\% Thermax }\end{array}$ & Sintered & 1.76 & 78.3 \\
\hline $0941-19$ & None & None & $-150+325 \mathrm{M}-3$ & Sintered & 1.43 & 63.6 \\
\hline $0938-1$ & 1 & $300 \AA$ & $-325 M-3$ & Sintered & 1.52 & 67.0 \\
\hline $0938-5$ & 5 & $300 \AA$ & $-325 \mathrm{M}-3$ & Sintered & 1.60 & 68.1 \\
\hline $0938-7$ & 7 & $300 \AA$ & $-325 \mathrm{~N}-3$ & Sintered & 1.63 & 68.2 \\
\hline $0938-14$ & 14 & $300 \AA$ & $-325 \mathrm{M}-3$ & Sintered & 1.78 & 69.7 \\
\hline $0938-20$ & 20 & $300 \AA$ & $-325 M-3$ & sintered & 1.91 & 70.6 \\
\hline 0939-1 & 1 & $1.3 \mu \mathrm{m}$ & $-325 M-3$ & Sintered & 1.55 & 68.3 \\
\hline $0939-5$ & 5 & $1.3 \mu \mathrm{m}$ & $-325 \mathrm{M}-3$ & Sintered & 1.60 & 68.1 \\
\hline $0939-7$ & 7 & $1.3 \mathrm{\mu m}$ & $-325 \mathrm{M}-3$ & Sintered & $1.80^{\mathrm{d}}$ & 75.3 \\
\hline $0939-14$ & 14 & $1.3 \mu \mathrm{m}$ & $-325 M-3$ & Sintered & 1.75 & 68.6 \\
\hline $0939-40$ & 40 & $1.3 \mu \mathrm{m}$ & $-325 \mathrm{M}-3$ & Sintered & 2.52 & 74.2 \\
\hline $0940-1$ & 1 & $40.0 \mathrm{\mu m}$ & $-325 M-3$ & Sintered & 1.52 & 67.0 \\
\hline $0940 . .5$ & 5 & $40.0 \mu \mathrm{m}$ & $-325 \mathrm{M}-3$ & Sintered & 1.57 & 66.8 \\
\hline $0940-7$ & $T$ & $40.0 \mu \mathrm{m}$ & $-325 M-3$ & Sintered & 1.60 & 66.9 \\
\hline $0940-14$ & 24 & $40.0 \mu \mathrm{m}$ & $-325 \mathrm{M}-3$ & Sintered & 1.75 & 68.6 \\
\hline $0,940-20$ & 20 & $40.0 \mu \mathrm{m}$ & $-325 \mathrm{M}-3$ & Sintered & 1.86 & 68.7 \\
\hline $0940-40$ & 40 & $40.0 \mu \mathrm{m}$ & $-325 \mathrm{M}-3$ & Sintered & 2.40 & 70.6 \\
\hline
\end{tabular}

- $325 \mathrm{M}-3$ has an everage particle size of $\sim 4.2 \mu \mathrm{m} . \quad-150+325 \mathrm{M}-3$ has an average particle size of $\sim 70 \mu \mathrm{m}$.

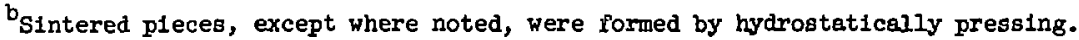

$c_{39.7}$ wt TaC-39.7 wt\$ NbC-20.6 wt c solid-solution composite.

Unusually high, unexplained.

B. Graphite

The varlous graphites investigated are as folLows: -200 mesh S-97, -325 mesh $\mathrm{M}-3$, standard $\mathrm{mix}$ (85 wt\% $\mathrm{M}-3+15 \mathrm{wt} \%$ Thermex), and $-150+325$ mesh $\mathrm{M}-3$. A sample of extruded standard $m i x$ that was cured, baked, and graphttized was also inclued for comparison.
Descriptions of all samples tested are presented In Table VIII, and both graphite and TaC-C samplee are included.

vI. TESTING

The thermal-stress and thermal-ohocle capabil1ties of materials in this investigation werc determined by using two methods that established temperature gradiento in material samples and established 
power or temperature levels necessary to initiate cracking or fracture. The firgt method, thermalstress method, ${ }^{5}$ was a steady-gtate test utilizing a flat washer specimen, 1.2-in.-0.d. by 0.5-1n.-i.d. by $1 / 16-1$ in.-thick, supported on its inside diameter by a water-cooled copper probe thermally coupled to a heat sink by copper conduction washers (Figs. 20 and 21). The outer rim of the washer received a heat flux by thermal radiation from a graphite radiator and the radial temperature gradient was created in the sample. Slow heating precluded any significant temperature transients. Successive radiator temperatures were trled (using different samples for each) until that temperature was achieved where a radial crack was initiated at the inside diameter of the sample. The crack initlation temperature (cIT) was the value reported.

The thermal-shock test induced heat in the outer rim of a washer, 1.0-inu-0.d. by 0.25-in.-i.d. by 1/16-in.-thick, by means of an $r f$ induction heating apparatus. The outer rim heated rapidly, producing a gradient between the inside and outside diameters, which equilibrated in about $1 \mathrm{sec}$. The rapid and large initial temperature difference produced the thermal shock. The failure manifested as a crack during the power application. The thermal-shock index (TSI) reported was aimply the power setting of the rf power supply.

Both steady-state and thermal-shock data were taken on washer samples whose planes were in the "kith-grain" direction (perpendicular to the direction of pressing) for hot-pressed material. Hydrostatically pressed materials were isotropic.

The coefficient of thermal expansion and dymamicmodulus measurements were made in an elastic-modulus furnace constructed from a design by H. L. Brokn and P. E. Armstrong of LASL Group CMF-13. Th1s furnece was used siaultaneously to measure elastic modulus and CTE of samples to temperatures of $2500^{\circ} \mathrm{C}$. The modulus-CIE furnace shell was a $6-3 / 4 \mathrm{in}$. inside diameter, 11-1/4 in. Inside length, horizontal watercooled cylinder slit lengthwise. The sample, 1/4in.-diam by 4-in.-long, with axis parallel to the pressing direction (where applicable) was supported In the center of a cylindrical radiator by three pointed graphite screws attached to a graphite ring which in turn was fastened at the center of the lower half of the radiator. When the furnece was closed, the radiztor and the skields surrounding it formed a cylindrical cavity around the specimen with a small horizontal slit through which the sample could be observed. The cross section of the rediator was varied to provide thinner sections on its ends. The hotter ends of the radiator thus achieved just offset the sample heat loss to the partially open ends of the radiator cylinder. Tests were conducted in an argon atmosphere at a pressure of about 2 in. of water.

Power was provided by a 45-KVA Burton Power Supply operating on single phase 60 cycle AC current. Temperature was measured up to about $1200^{\circ} \mathrm{C}$ by a Cnromel-Alumel thermocouple contacting the sample support ring. Above $1200^{\circ} \mathrm{C}$, temperature inside the furnace was measured with a Leeds \& Northrup optical pyrometer sighting on the semple surface through the center part of the furnace.

The change in length of the specimen was measured using twin microscopes to view two fiducial marke on the specimen. The moduIus was meesured by passing an ultrasonic sound wave through the sample and measuring the vibrations.

Both phenomenes were measured sinultaneously in the following manner. The sample was hested to $e$ desired temperature, the temperature was stabllized, and the driver and pickup wires were coupled into holes in the sample. Using a micrometer drive, the wires vere adjusted to yield maximum signal transfer to and from the sample. Next, the spectrus was scanned for proper reasonance frequency and the overall length of the specimen was measured with the twin microscopes. The modulus is proportional to the square of the reasonance frequency and may be calculated. At each stabilized tenjerature the change in the specimen length was measured to determine thermal expansion characteristica.

Thermal-conductivity measurements wers made usIng a probe comparator apparatus comprising a tungsten hemisphere and adjecent thermocouple. Measurements were made on experimental material and cal1brated against a known standard. The samplas were 1 in. dian by $1 / 4$ in. thick.

\section{DISCUSSION OF RESULIS}

The flrst group of samples tested was made up of hot-presed material containing to wt\% (10 vol\%) TaC of differing particle sizes, or, in the case of 
Sample S $.006 \mathrm{D}, 10$ volf of a 50/50 wto solid solutaon of NoC-TaC. This $\mathrm{NbC}-\mathrm{TaC}$ sample was included for comparison. The samples tested (2111A, 2108A, 2106A, 2141A, and $S-4006 D)$ are described, as are all tested samples, in Table VIII. This description includes composition, fac size if applicable, fabrication technique, and densities. Preliminary invests gation of structure by conventional metallographic means Indicated excellent distribution of TaC particles within the graphite phase (Fig. 22). This was confirmed by subsequent scanning electron micrographs presented in Figs. 23 through 28. The desired chemical analyses and actuel chemical analyses of some samples of tinis group are presented in Taole IX. Good composition cortrol was achleved.

Testine results of themal properties are presented in Table $X$. Values for all samples tested are present. Values are omitted only if sample material was not availeble. From the hot-pressed conposite, samples listed above, several conclusions were drawn. It appeared that 2111A $(0.13 \mu \mathrm{m}), 2141 \mathrm{~A}$ $(1.3 \mathrm{\mu m})$, and $2108 \mathrm{~A}(1.2 \mathrm{\mu m})$ were similar in thermalfracture resistence, and that $2106 \AA$ ( $300 \AA$ ) hat much poorer resistance. Thernal-stress resistance seems to Increase with increasing carbide particle olze a].though it is less proncunced with the three largersized particies than with the $300-\AA$ material. All TaC-C compoeites were signiflcantly less resistant than the solid-solution composite $\{S-4006 \mathrm{D}$ \}, probably due to the Varcum binder in the TaC samples and other ifferences in the grephite phase.

Determinations of dynemic elestic (Young's) modulus and thermal expansion results are presented in Table $X$, whereas Figs. 29 through 33 show some of the temperature dependences of these properties. Modulus behavior for the Tac-C composites was quite simlar to the $\mathrm{NbC} . \mathrm{TaC}-\mathrm{C}$ material, but the thermal expansion values were much lower.

Materials of the same composition were then produced utilizing hydrostatic pressing and sintering rather then hot pressing (Samples 101 and 102). The results showed little change in thermal-fracture resistance from the hot-pressed materials. The only change discernable was a slight iraprovement in the samples tested under steady-state conditions. Lower densities than those found in the hot-pressed materials were noted.

Testing hydrostatically pressed and sintered graphites produced an interesting trend. In the pro.
Those Ix

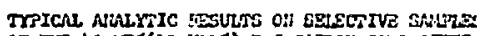

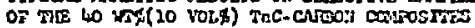

\begin{tabular}{|c|c|c|c|c|c|c|}
\hline \multirow[b]{2}{*}{$\begin{array}{l}\text { Souple } \\
\text { lio. }\end{array}$} & \multicolumn{3}{|c|}{ Deo1red findyoes } & \multicolumn{3}{|c|}{ Actual Analyoes } \\
\hline & $\begin{array}{l}70 \\
\text { (क) }\end{array}$ & $\begin{array}{l}\text { Total C } \\
\text { (B) }\end{array}$ & $\begin{array}{c}\text { Ffooc } \\
(\$)\end{array}$ & (\$) & $\begin{array}{l}\text { Toral C } \\
\text { (d) }\end{array}$ & $\begin{array}{l}\text { Preec } \\
(\$)^{2}\end{array}$ \\
\hline $2106 \mathrm{~A}$ & 37.5 & 62.5 & 60.0 & 37.0 & 42.9 & 61.7 \\
\hline $2108 \mathrm{~A}$ & 37.5 & 62.5 & 60.0 & 37.9 & 61.7 & 59.3 \\
\hline $2111 \mathrm{~A}$ & 37.5 & 62.5 & 60.0 & 37.5 & 62.4 & 59.8 \\
\hline
\end{tabular}

viously tesced rateriale containing $T w C$, an increase in thermal-shock index vas accompanied by a conconitant increase in crack initiation temperature, cut this wes not trie for the Eraphites teoted. In fact, the graphite with the inghest TSI (-200 mesh S-97) hed the lowest CIT; and conversely, the graphite with the hichest $\operatorname{cIs}(-150+325$ mesh $M-3)$ hod the 1owest TSI. Although narised differences in structure can be seen in the photomicrographs and scoming merographs of Figs. 34 through 39 , little dirference exists in TOI except with the 5-97. CTI values, however, Indleate better performance by the $-150+325$ mesh $\mathrm{H}-3$. Unfortunately no photonicrograph of the -200 mesi 5-97 structure is evallable for comparison. The high room-temperature modulus of the S-97 sample was compared with that of an extruded standerd $m i x$ to check for comparable values, and was found to be lower.

In the final phese of this investigation, samples were made varying both the particle slze and the amount of Tac used in the composite material.

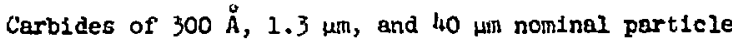
olzes were lised in amounts ranging from 1 to $40 \mathrm{wt}$. Conventionel and scanning electron micrographs are presented of the composite material containing $300-$

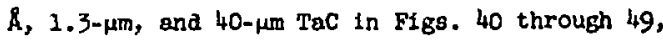
$\mathrm{Fl}_{\mathrm{gs}}$. 50 through 59 , and $\mathrm{FIgF} .60$ through 71 , respectively. They reveal the exselient distribution of carbide in the graphite. The thermal-shock test showed that the coarse TaC produced the best thermalfracture resistance. Indeed, by using particles differing in stze by at least an order of angnitude, a distinction could easily be made between the thermal-gtress resiatence improvement of ench size range.

A tangential study demonstrated the need for thermally shocking a specimen only once. It aseerted that when specimens are shocked more than once, they can withotand greater thermal ahocks than virgin ma- 
THBLE $x$

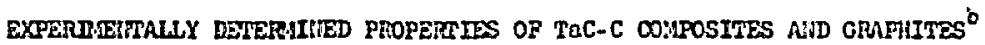

\begin{tabular}{|c|c|c|c|c|c|}
\hline $\begin{array}{c}\text { Sample } \\
\text { Ho. } \\
\end{array}$ & $\begin{array}{l}\text { Therral Shock } \\
\text { Index (T'SI) }\end{array}$ & $\begin{array}{c}\text { Crack } \\
\text { In1t1atton } \\
\text { Texp (CIT) }\end{array}$ & $\begin{array}{l}\text { foom Temp } \\
\text { Elastic Modulus } \\
\text { (AG) } 1 \mathrm{~b} / \mathrm{Ln}^{2} \times 10^{\circ} \\
\end{array}$ & $\begin{array}{c}\text { Thacrma Expangion } \\
\left(20-2000^{\circ} \mathrm{C}\right)(\Lambda \mathrm{G}) \\
\times 10^{\circ} \mathrm{C} / \mathrm{C}\end{array}$ & $\begin{array}{l}\text { Conductivity } \\
\left.\text { (at } 33^{\circ} \mathrm{C}\right) \\
\mathrm{W} / \mathrm{m}-\mathrm{K} \\
\end{array}$ \\
\hline $2112 \mathrm{~A}$ & $415 / 435$ & 2000 & 1.131 & 6.638 & -- \\
\hline $2108 \mathrm{~A}$ & $430 / 435$ & 2055 & 2.054 & 6.357 & $\cdots$ \\
\hline $2106 A$ & $390 / 395$ & $1 \hat{c}$ & $\cdots$ & -- & $-\circ$ \\
\hline $2142 \pi$ & $420 / 425$ & 1985 & 2.174 & 6.645 & -- \\
\hline$s-1,0060$ & $460 / 1465$ & 2370 & 2.167 & 7.792 & -- \\
\hline 101 & $395 / 4: 00$ & 1835 & -- & -- & -- \\
\hline 202 & $44<0 / 425$ & 2050 & -- & -- & -- \\
\hline 0924 & $400 / 405$ & 1405 & 1.526 & 4.783 & -- \\
\hline$E-\infty 01$ & -- & -- & 2.339 & 3.670 & $-\cdot$ \\
\hline $0941-4$ & $305 / 307.5$ & 17140 & $\cdots$ & -- & 1.40 \\
\hline $0941-16$ & $310 / 312.5$ & 2860 & $-\cdot$ & $\cdots$ & 1.28 \\
\hline $0941-19$ & $300 / 302.5$ & 1920 & -- & -- & 1.28 \\
\hline $0938-1$ & $\cdots$ & $<1475$ & $-\cdot$ & -- & $-\cdot$ \\
\hline $0938-5$ & -- & 1700 & -- & -- & 1.44 \\
\hline $0938-7$ & $\cdots$ & 1950 & $\cdots$ & -- & -- \\
\hline $0958-14$ & $312.5 / 315$ & -- & -- & -- & -- \\
\hline $0938-20$ & $297.5 / 500$ & 1825 & -- & $-\cdot$ & $-\cdot$ \\
\hline 0939-1 & $280 / 282.5$ & 1890 & -- & $\cdots$ & 1.35 \\
\hline $0939-5$ & $300 / 305$ & 1680 & -- & -- & 1.43 \\
\hline $0939-7$ & $297.5 / 315$ & 2990 & -- & $\cdots$ & 1.39 \\
\hline $0939-14$ & $335 / 337.5$ & 1970 & -- & -- & -- \\
\hline $0939-40$ & $320 / 322.5$ & 1910 & $\cdots$ & -- & 1.39 \\
\hline $0940-1$ & $300 / 302.5$ & $<1570$ & -- & -- & 1.40 \\
\hline $0940-5$ & $335 / 337.5$ & 1885 & -- & $\cdots$ & 1.40 \\
\hline $0940-7$ & $347.5 / 350$ & -- & -- & -- & $\cdots$ \\
\hline $0940-14$ & $345 / 350$ & 2100 & -- & $\cdots$ & 1.39 \\
\hline $0940-20$ & $325 / 327.5$ & 1955 & - & -- & 1.41 \\
\hline $0940-40$ & $337.5 / 340$ & 2000 & -- & -- & 1.33 \\
\hline
\end{tabular}

The f1rst number indicates the highest power setting prior to one that initiated cracking. The second number indicates the power setting at which cracking occurred. Because a number of samples are run, more than one increment may separate the two numbers.

bontted values indicated no sample available for testing.

TABLE XI

THERALL SHOCK RECYCLING

terial. Table XI shows the effect of repeatedly subjecting specimens to increasingly higher levels of thermal shock. Recycled opecimens fracture at higher power levela than do virgin materials.

Probably the most meaningful information generated in the final phase investigation came from

\begin{tabular}{|c|c|c|c|c|c|}
\hline Sample & & Cycl & g Runs & ower S & tings \\
\hline No. & TSI & Fiun 1 & Run 2 & Run 3 & Run 4 \\
\hline $0940-14$ & $345 / 350$ & 320 & 340 & 360 & $380^{\mathrm{a}}$ \\
\hline $0940-20$ & $325 / 327.5$ & 320 & 340 & $360^{a}$ & \\
\hline $0940-40$ & $337.5 / 340$ & 320 & 340 & 360 & $380^{\circ}$ \\
\hline
\end{tabular}

Bracture. 
TABLE XII

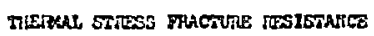

\begin{tabular}{|c|c|c|c|c|c|}
\hline $\begin{array}{l}\text { Enteple } \\
\text { Na. }\end{array}$ & $\mathrm{crs}\left({ }^{\circ} \mathrm{C}\right)$ & $\therefore$ & $\left(y^{\lambda}={ }^{*} \cdot\right)^{0}$ & $\underline{\pi I} \times 20^{-12}$ & Resting \\
\hline $0941-4$ & 1740 & 0.70 & 1.40 & 8.2 & 1.0 \\
\hline $0941-16$ & 1860 & 0.70 & 1.28 & 11.0 & 2.3 \\
\hline $0942-19$ & 1960 & 0.70 & 2.28 & 23.0 & 1.6 \\
\hline $0938-1$ & $<1475$ & 0.90 & $(3.44)^{c}$ & 6.0 & $<0.73$ \\
\hline $0938-5$ & 1700 & 0.90 & 1.44 & 9.0 & 1.2 \\
\hline 0938.7 & 1950 & 0.90 & $(1.44)$ & 15.0 & 1.8 \\
\hline $0938-20$ & 2825 & 0.90 & $(1.44)$ & 12.0 & 1.5 \\
\hline $0939-1$ & 1890 & 0.90 & 1.35 & 15.0 & 1.8 \\
\hline $0939-5$ & 2680 & 0.90 & 1.43 & 9.0 & 1.1 \\
\hline $0939-7$ & 1950 & 0.90 & 1.39 & 17.0 & 2.1 \\
\hline $0930-14$ & 2970 & 0.90 & $(1.39)$ & 16.0 & 2.0 \\
\hline 0939.40 & 1910 & 0.90 & 1.39 & 15.0 & 1.8 \\
\hline $0940-1$ & $<2570$ & 0.90 & 1.40 & 7.0 & $<0.85$ \\
\hline $0940-5$ & 2885 & 0.90 & 1.40 & $\begin{array}{l}14,0 \\
.014\end{array}$ & $=1+x+3$. \\
\hline $091: 0-24$ & 2200 & 0.90 & 2.39 & 2.0 & 2.6 \\
\hline $0940-20$ & 1955 & 0.90 & 1.41 & 16.0 & 2.0 \\
\hline $0910-40$ & 2000 & 0.90 & 1.33 & 18.0 & 2.2 \\
\hline
\end{tabular}

\footnotetext{
Thoos tcrpereture values.

belative to busle grophite matrix, 0941-4.

Acasped.
}

tine steady-state thermal-stress fracture studies and the thermal-conductivity measurements. Previous steady-state tests produced a crack initiation temperature used to rank materials. These CIT's did not give quantitative comparisons of thermal-fracture resistances, but insteed geve only rankings. A new thermal-stress fracture resistance was introduced in tnis final phase. This parameter, TGI, ${ }^{6}$ depends upon the emsosivity, thermal conductivity, and CIT, and is a function of the relative temperature Bradient existing in the sample at crack initiation. This parameter may be used in a quantitative sense to rate materials and to ascertain how much better one is than another. The expression for this parameter is as follows.

$$
\operatorname{TGI}=\frac{e_{E}(\operatorname{crT})^{2}}{\lambda_{8}}
$$

where $C_{B}=$ emigsivity,

$$
\begin{aligned}
& C I T=\text { crack Initiation temperature, and } \\
& \lambda_{8}=\text { thermal conductivity. }
\end{aligned}
$$

The values of TGI are presented in Table XII. In addition to the TaC-C composites of this phase of the investigation, the TGI's for the graphites of the previous phase are offered. The final column of Table XII is a rating relative to the basic -325 mesh $U-3$ graphite matrix that was present as $0941-4$. fiding TaC improved tive thermal-stregs fracture resistance of the compusite material in all but two cases. In addition, the larger the size of the Tac particle, the higher the thermal-stress fractlire

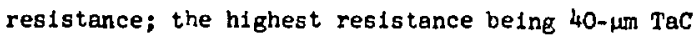
particlee. No explanation is avallable for the extremely low themal-stress fracture resistance of materials 0938-1 and 0940-1. The hichest fracture resistance of any material tested was for the speci-

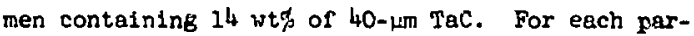
ticle size range, the manimum thermal-stress fracture resistance occurred at intermediate levels of $\mathrm{TaC}$ addition, elther 7 or $14 w t \%$. For the pure graphite samples, the $-150+325$ mesh $H-3$ appeared to be the most resistent to thermel-stress fracture.

\section{CONCLUSIONS}

From this study it became evident that TaC-C composites or 100\% graphite materials could be produced in a well-controlled manner, the materials exhiblting little varlability with respect to density, carbide particle distribution, chemistry, modulus, thermal expansion, and thermal shock characteristics in samples of similar composition.

Thermal properties vere investigated both to establish baseline velues and to understend the effects of variables upon these values. It became evident that the particle size of the carbide affected the thermal-expansion characteriatics of the material and the elastic madulus and that thermal-stress fracture resistance was dependent spon the size and relative amounts of both the TaC and grapite in the composite.

Thermal expansion of samples differing only in the particle size of carbide used wes greater for the specimens containing the finer TaC, but was much lower than the NoC-TaC solid solution graphite composite tested. Dynamic elastic modulus of the specimens concaining the finer TaC was higher than 1 to coarse counterpart, and both showed a close relationship to the NoC.TaC-C material. Adding TaC to graphIte appears to improve the thermal-8tress fracture resistance of the araphite, the larger the $81 z e$ of the TaC particle the greater the fracture resistance Induced. Of the pure graphites teated, the $-150+325$ mesh fraction appeared to be the most reaistant to thermal-stress fracture. 


\section{ACRTOLTLDCAEMTS}

The authors expreco approctebion to tac lollosInE LAsL people dor thetr ueststance in thio fivestigation: T. I. Jones and C. Javorsty of she physical Hetallurgy Section for conventional metallography; S. Sandova? for lllustretions; R. Andree, C. King, C. Saunders, and $H$. Sibbitt of Group $\|-7$ for thermal-stress fracture, thermal expansion, and thermal conductivity measurements; Groug $C B-1$ for chemical analyses; J. Magnuson for powder characterization; T. Gregory for scanning electron microscupy; A. Lovato for hot pressing; the Shops Department for machining or aamples; and H. Sheinberg and J. T. Frakes for supervision of the billet menufacture.

\section{REFEREICES}

1. K. V. Davidson, R. E. Riley, and J. M. Taub, "Carbide-Graphite Composites," Los Mlarns Sc1ent1f1c Laboratory report LA-3569-is (Oct. 1966).

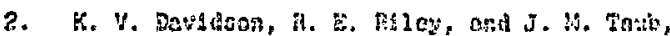

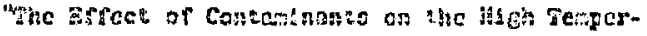

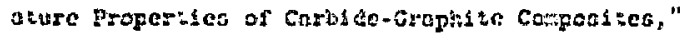

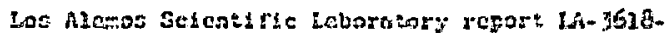
lis (Jan. 2967).

3. K. V. Davidson, R. E. Rfley, and J. M. Teub, "Carbide-Grapinte Composites. Second Progress Report," Los Alanos Scientific Laboratory report LA-3652-isS (June 1957).

4. R. E. Riley, H. K. Richerson, and D. H. Schell, "Extruded Carbiele-Graphite Composites," Los Maros Sclentific Laboratory report LA-4077 (Feb. 1969).

5. A. E. Carden and R. W. Andrae, "Thertial-stress Crack Initiation Method of Resting Ceranie Materialo," J. Mer. Ceranic Soc. 53, No. 6 (June 1970).

6. R. W. Andrae, Los Alamos Seientifye Laboratory internal docunent (April 1971).
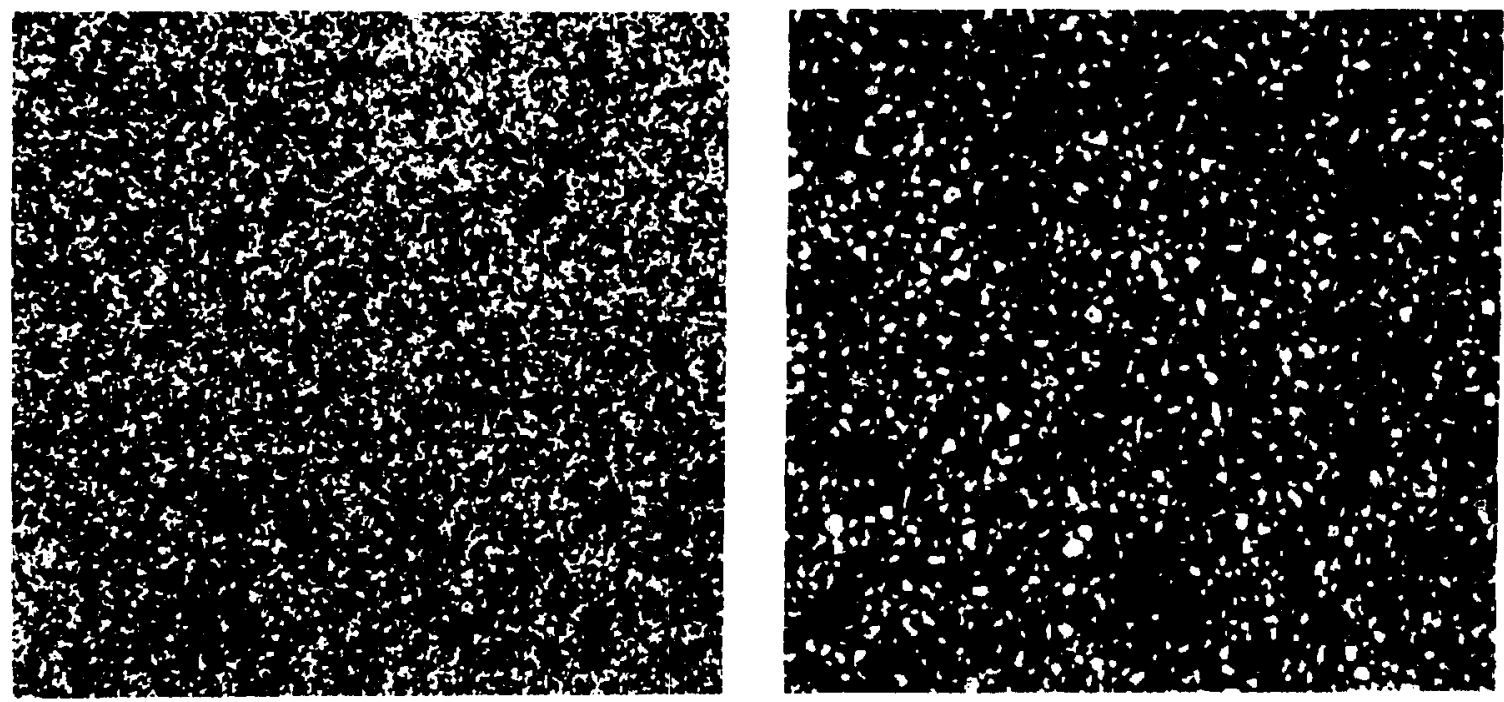

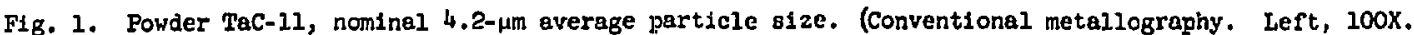
Right, 250X.) 

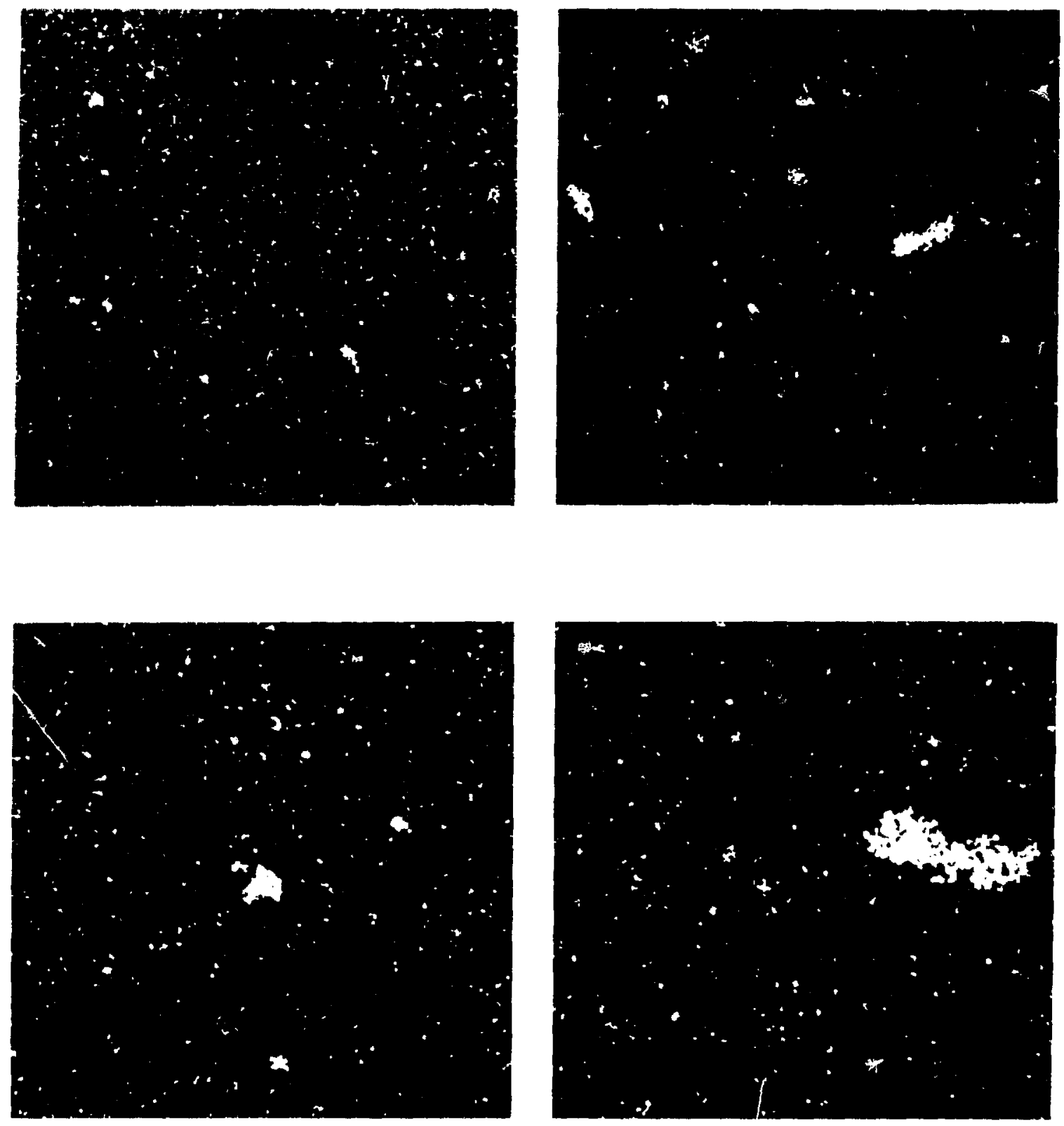

F18. 2. Powder TaC-29, nominal 1.3- $\mu$ m average particle a1ze. (Conventional metallography. Top, 100x. Bottom, 250X.)

F1g. 3. Powder TaC-30, nominal 1.37- $\mu \mathrm{m}$ average particle ilze. (Conventional metallography. Top, 100x. Bottom, 250x.) 

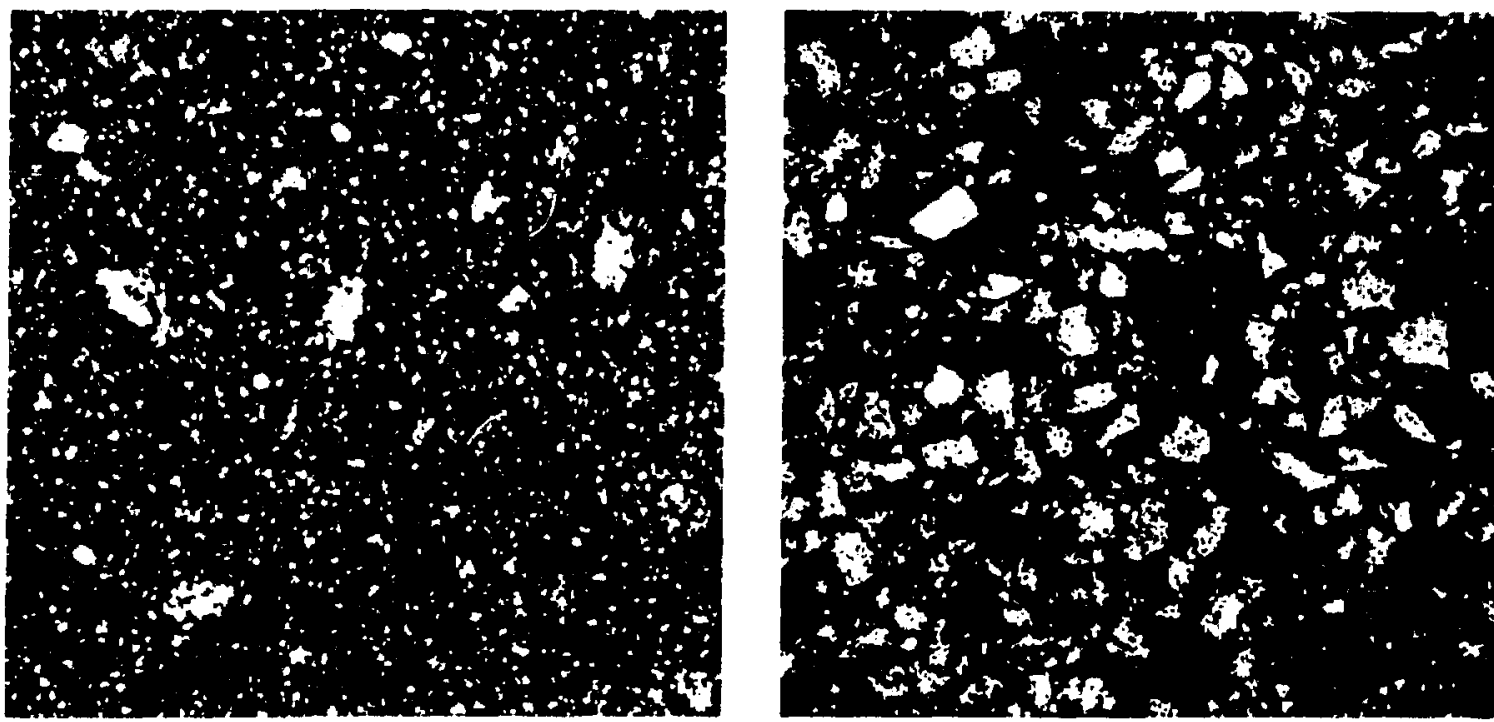

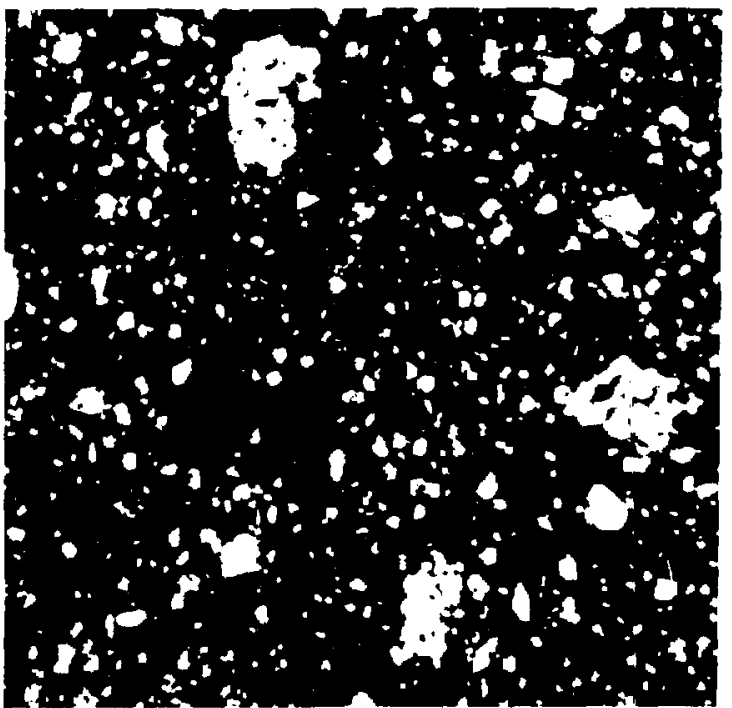

F1g. 4. Powder TaC-32, nominal 1.85- um average particle alze. (Conventional metallography. Top, 100X. Bottom, 250X.)

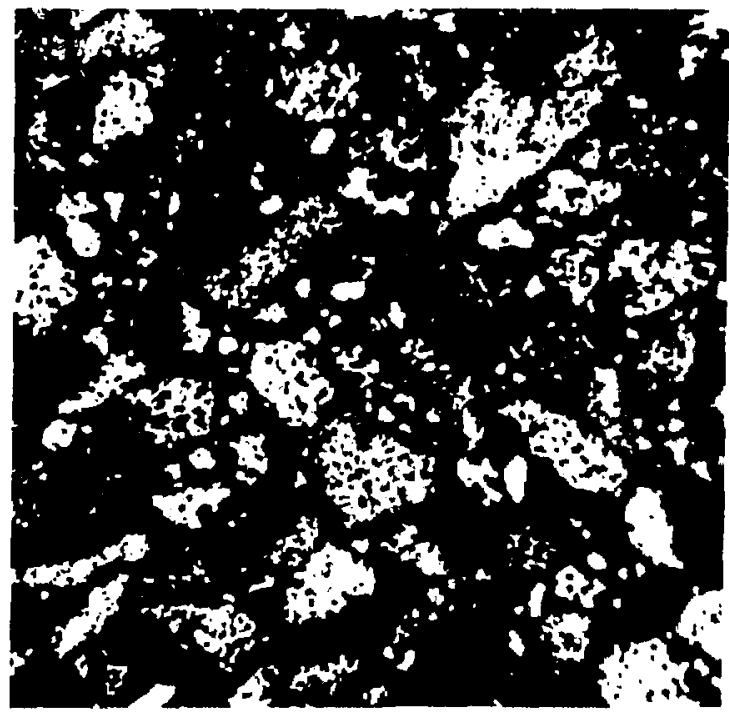

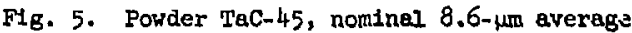
particle size. (Conventional metallography. Top, 100x. Bottom, 250x.) 

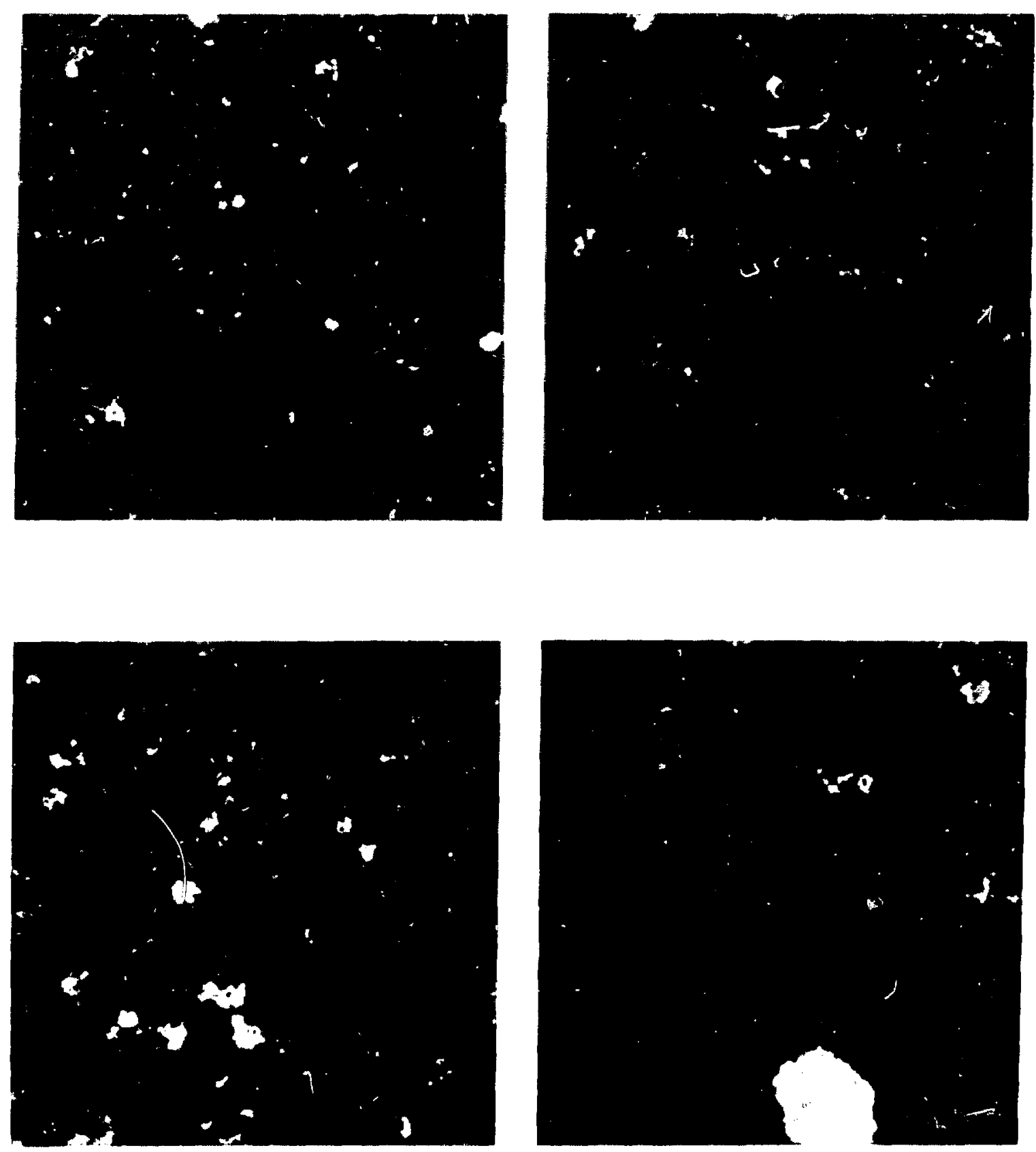

F1g. 6. Nominal 300- $\AA$ average particle b1ze. (Scanning electron micrographe. Sample TaC-38. Top, 1000X. Bottom, 3000X.)

F1g. 7. Nominal $300-\AA$ average particle o1ze, (Scanning electron micrographs. Sample TaC-38. Top, 5000X. Botton, 5000X.) 

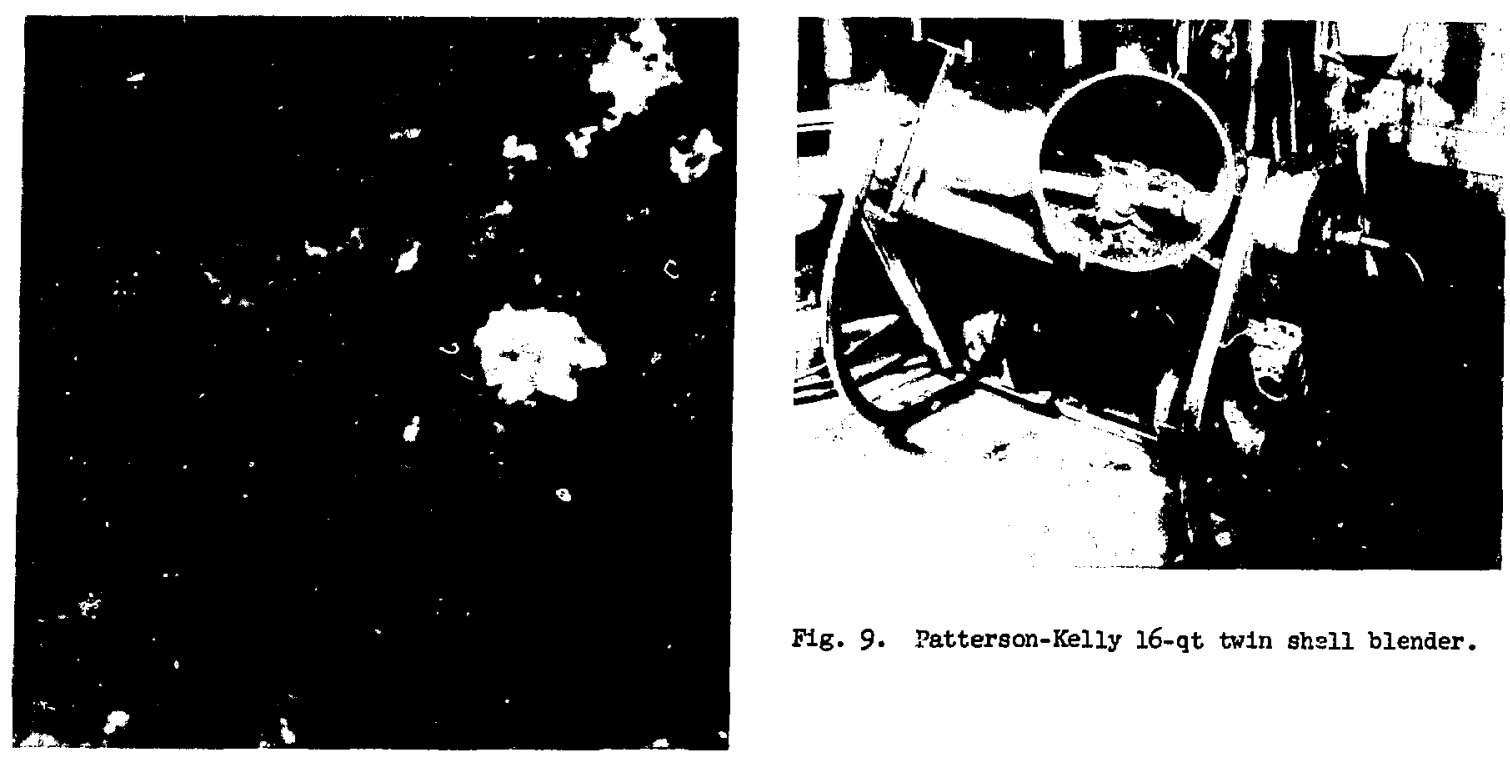

F1g. 9. Patterson-Kelly 16-qt twin shall blender.
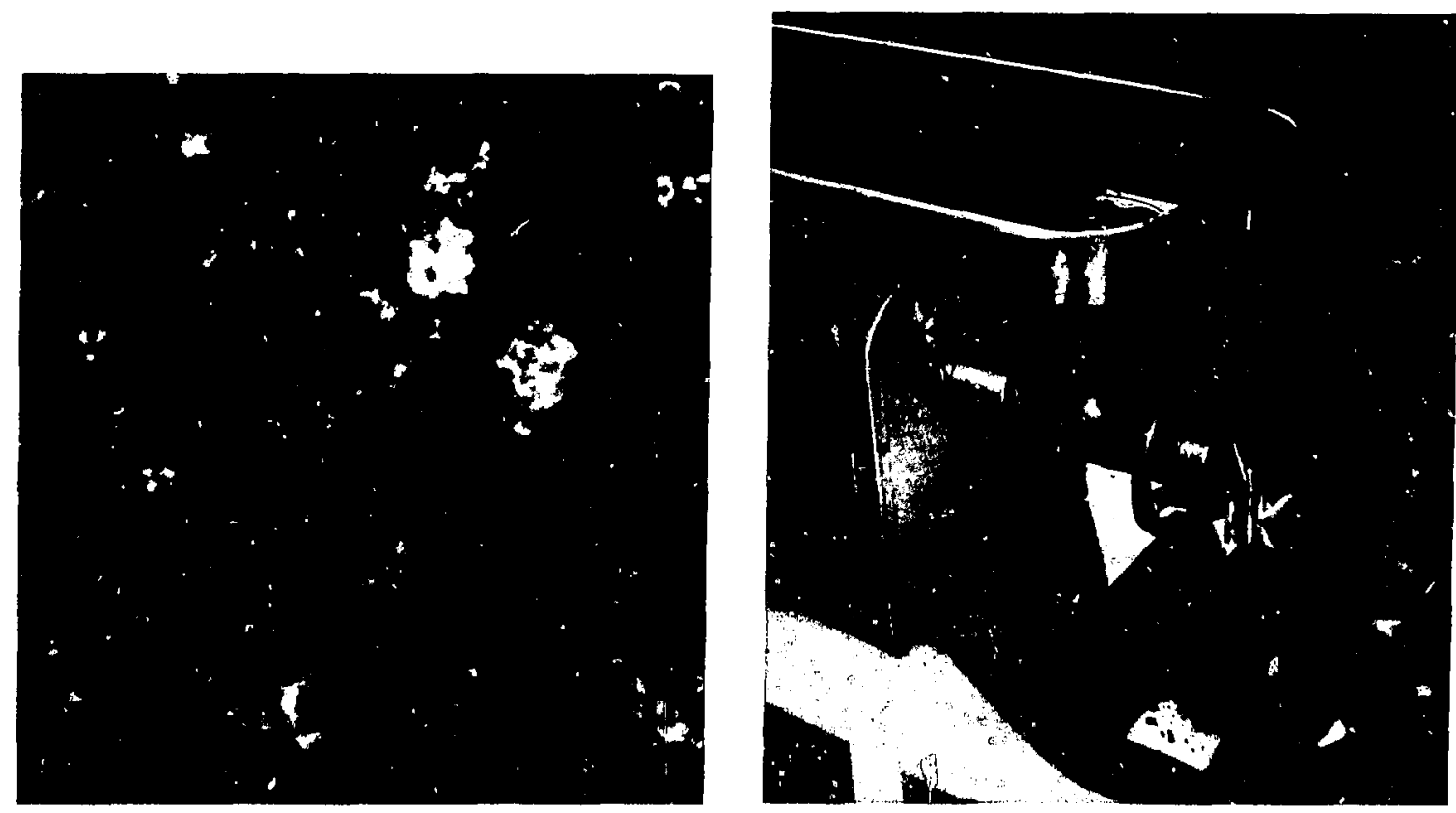

F1g. 8. Nominal 300- $\AA$ average pertlcle size. (Scanning electron micrographs. Sample Fig. 10. Hobart chopper with $\mathrm{mix}$. 


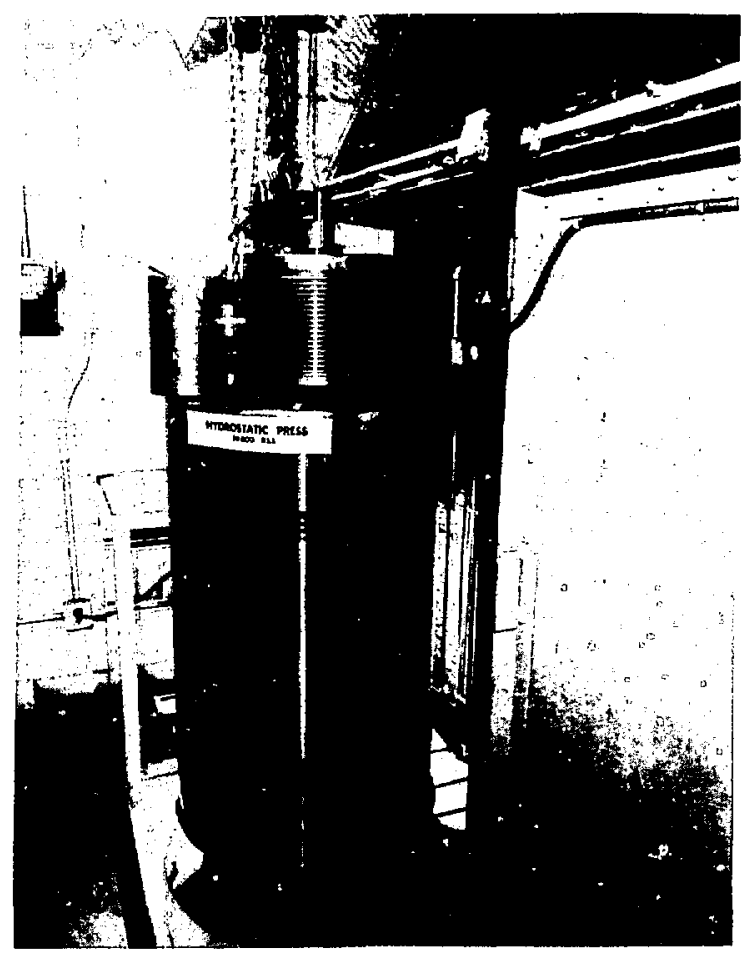

Fig. 11. Hydrostatic press.

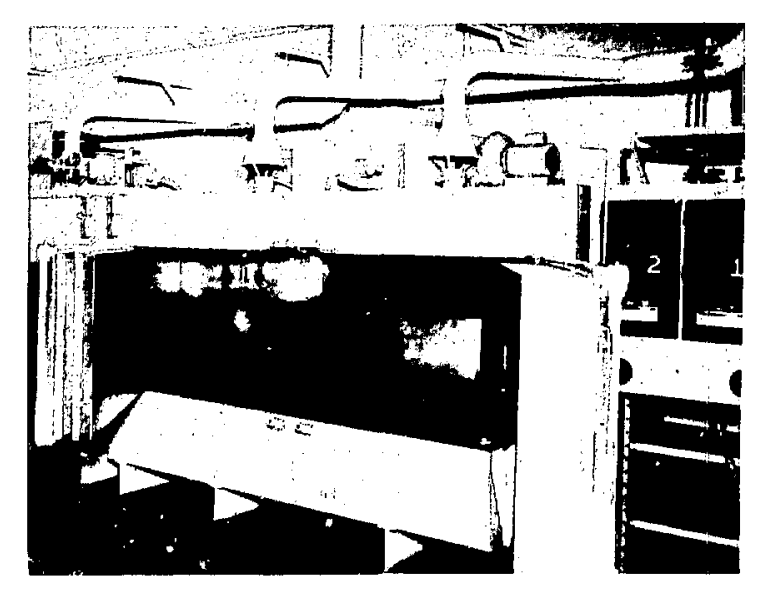

Flg. 12. Curing oven.

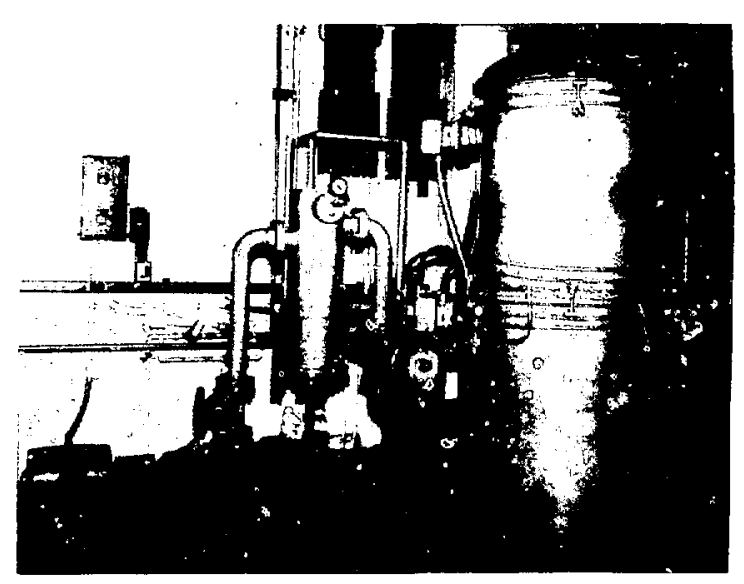

FIg. 13. Baking furnace.

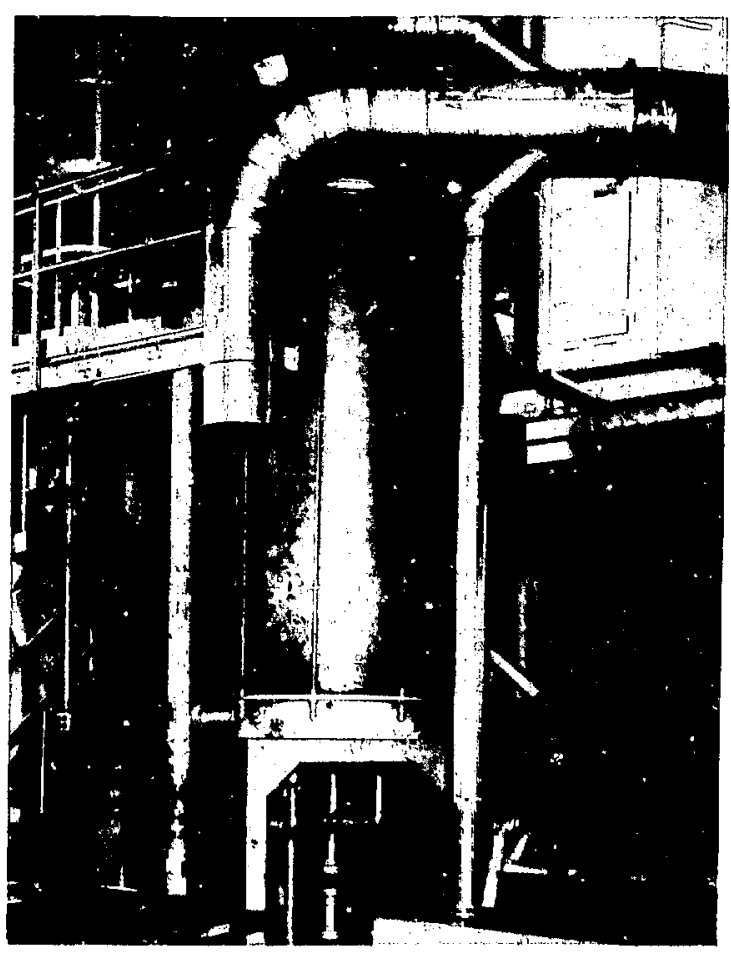

F1g. 14. Sintering furnace. 


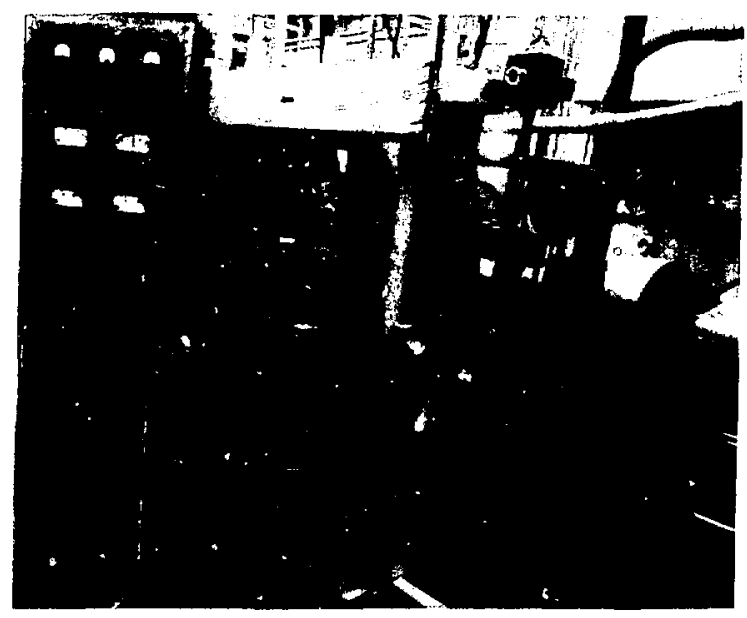

Fig. 15. HIgh-temperature sintering furnace.

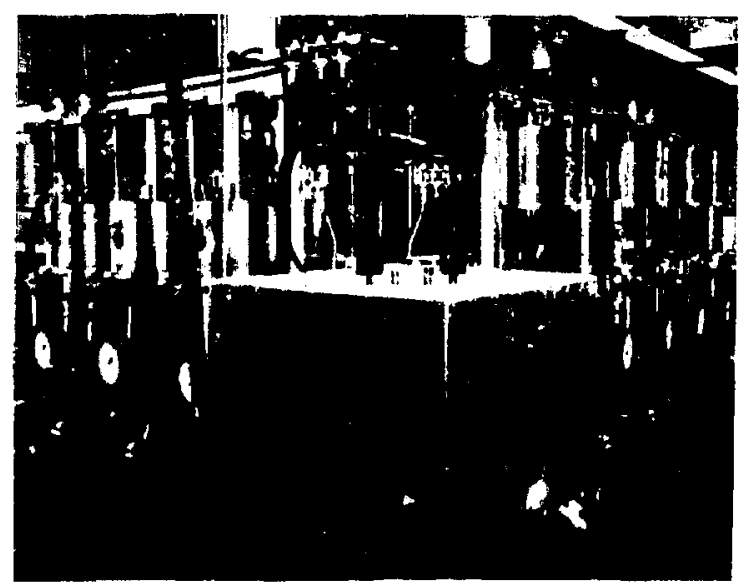

FIg. 16. Hot-pressing furnaces.

FIB. 17. Schematic drawing of hot-presaing furnace. 


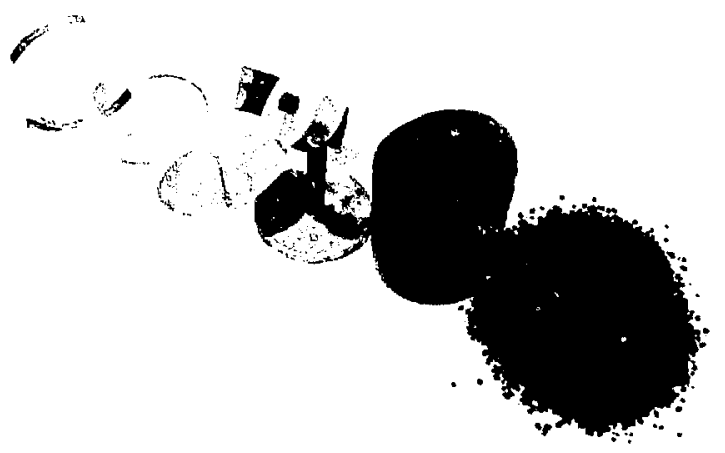

F1g. 18. Pressing sack components: (left to right) Aero seal clamp, clamping ring, lid with hypodermic needle penetrating into sponge, tamper, sack, and mix.

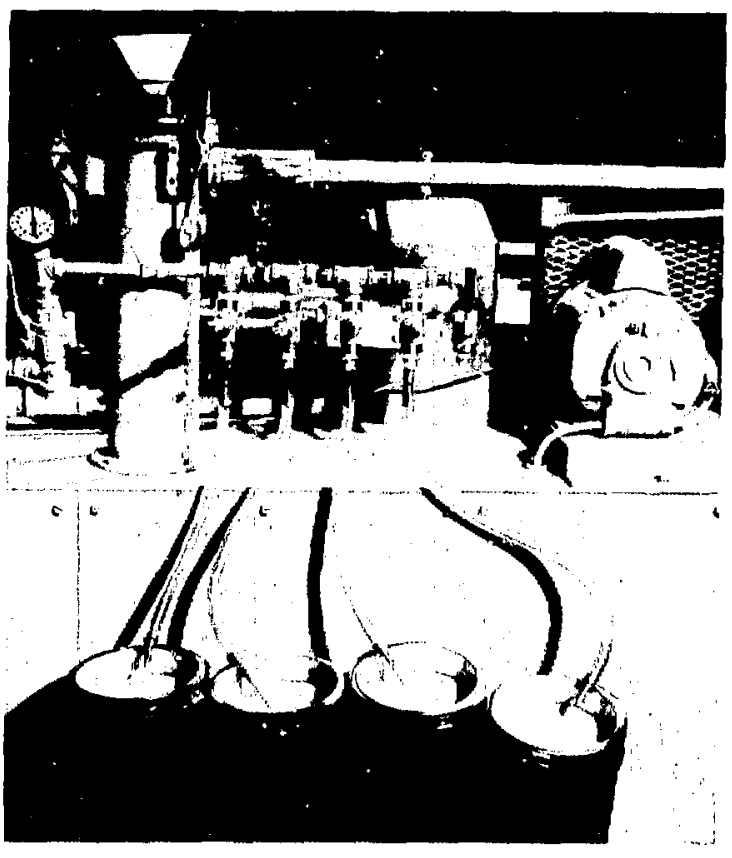

Fig. 19. Evacuetion of pressing aacks.

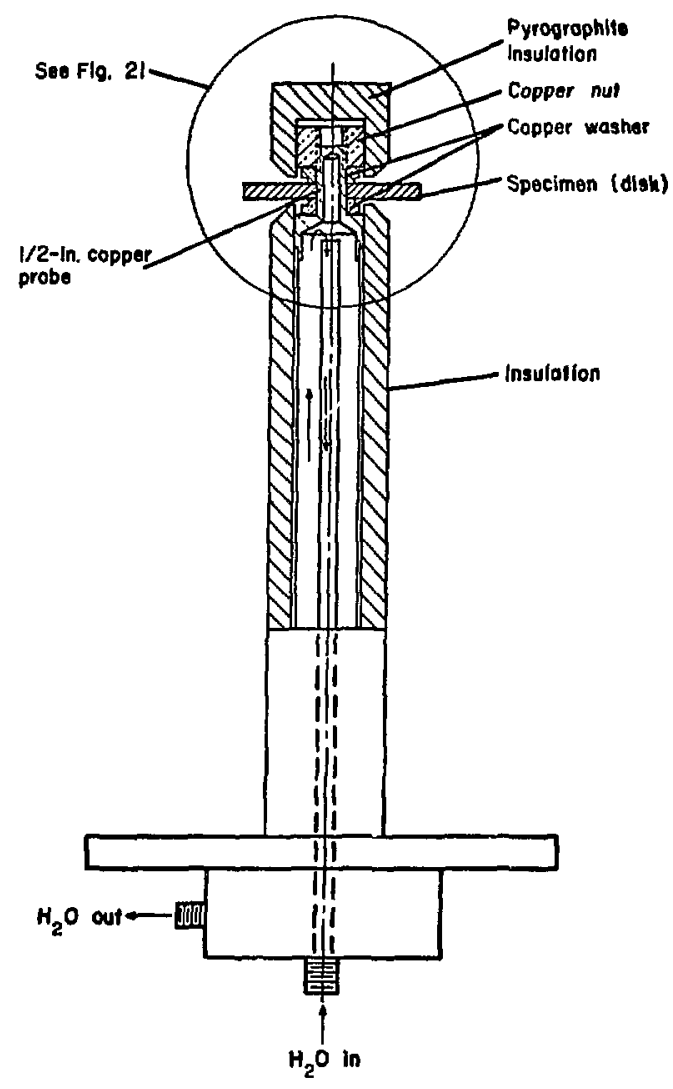

Fig. 20. Steady-state thermal stress test rig.

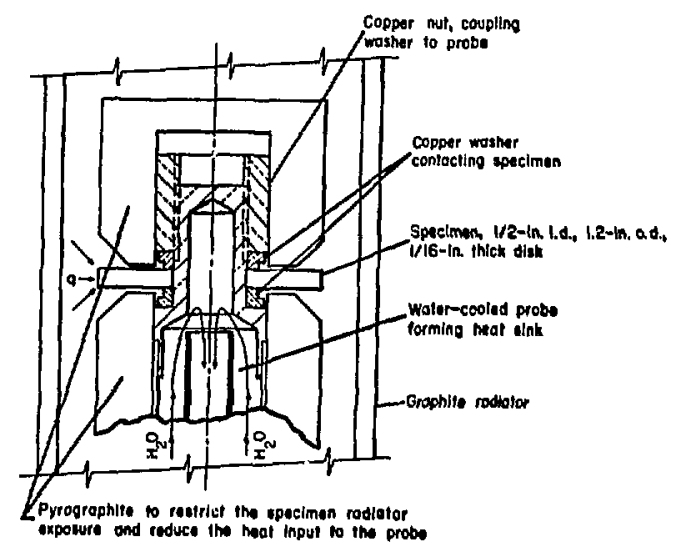

F1g. 21. Enlargement of part of Fig. 20. 


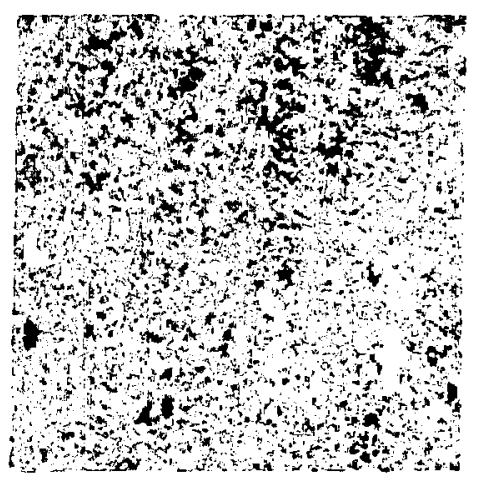

(a) 100x.

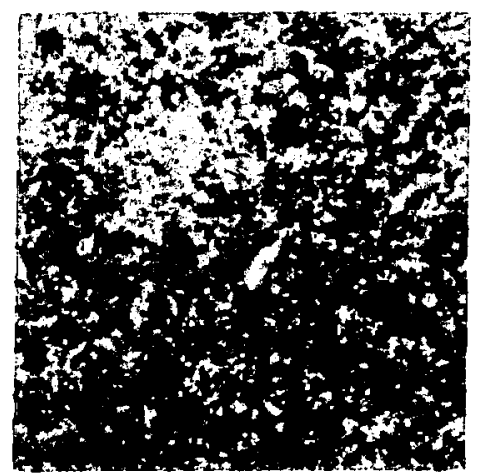

(b) $100 x$.

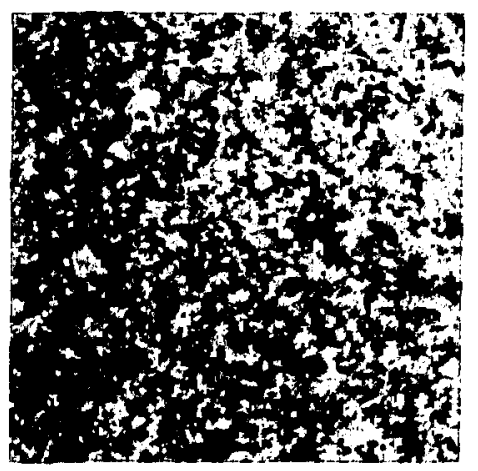

(c) $200 x$.

Fig. 22. Microstructure showing the distribution in a graphite matrix of TaC with an APS of (a) $300 \AA$, (b) $0.13 \mu \mathrm{m}$, and (c) $4.2 \mu \mathrm{m}$.

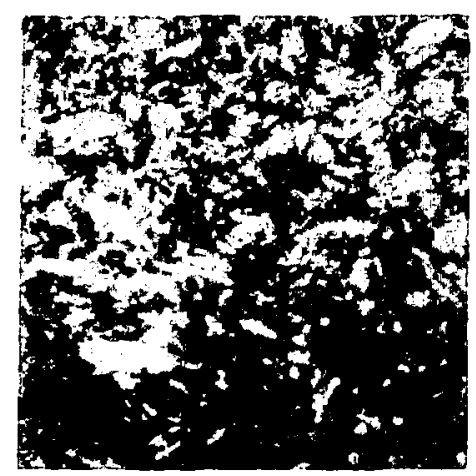

(a) 250x.

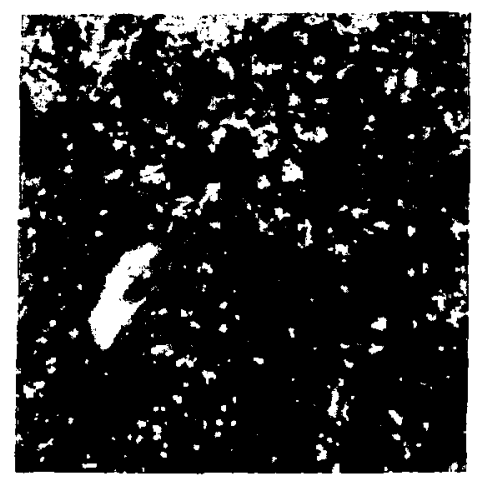

(b) $250 x$.

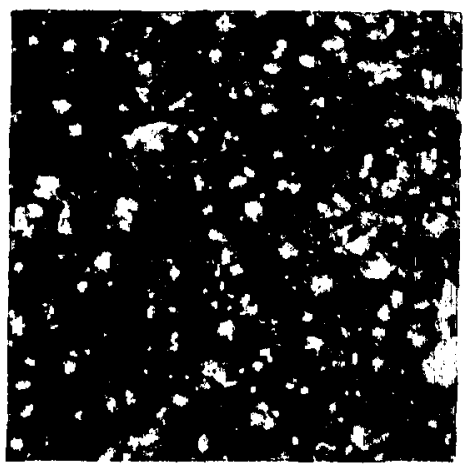

(c) $250 x$. 

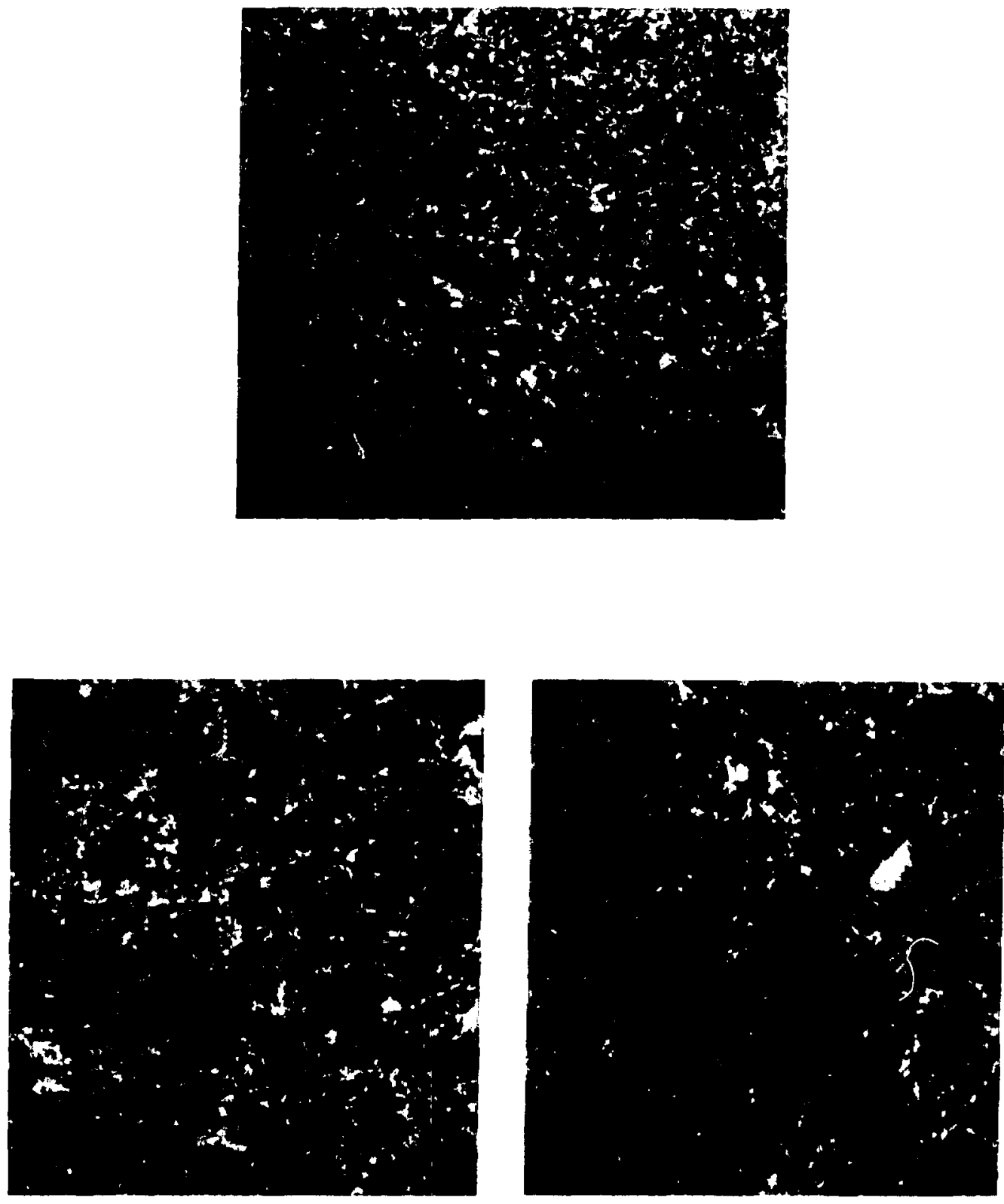

Fig. 23. Structure of $40 \mathrm{wt} \not(10 \mathrm{vol} \%)$ TaC ( 300 Å)-carbon compoal te. (Scanning electron micrographs. Top, 100x. Bottom left, 300x. Bottom right, 500x.) 

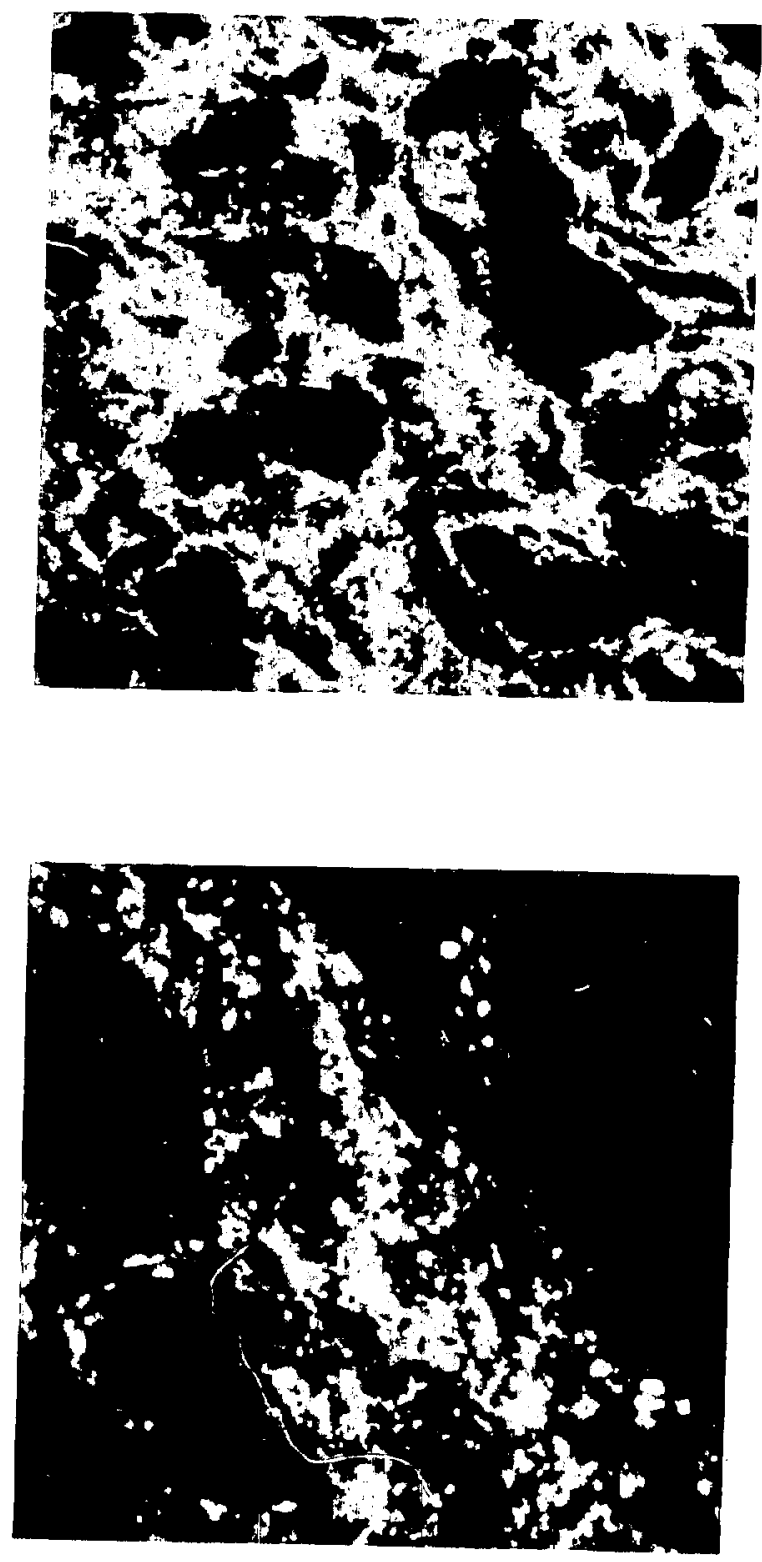

Fig. 24. Structure of $40 \mathrm{wt},(10 \mathrm{vol} \%)$ Tac $(300 \AA$ A)-carbon composite. (Scanning electron mlcrographs.
Top, 1000x. Bottom, $3000 \mathrm{x}$.) 

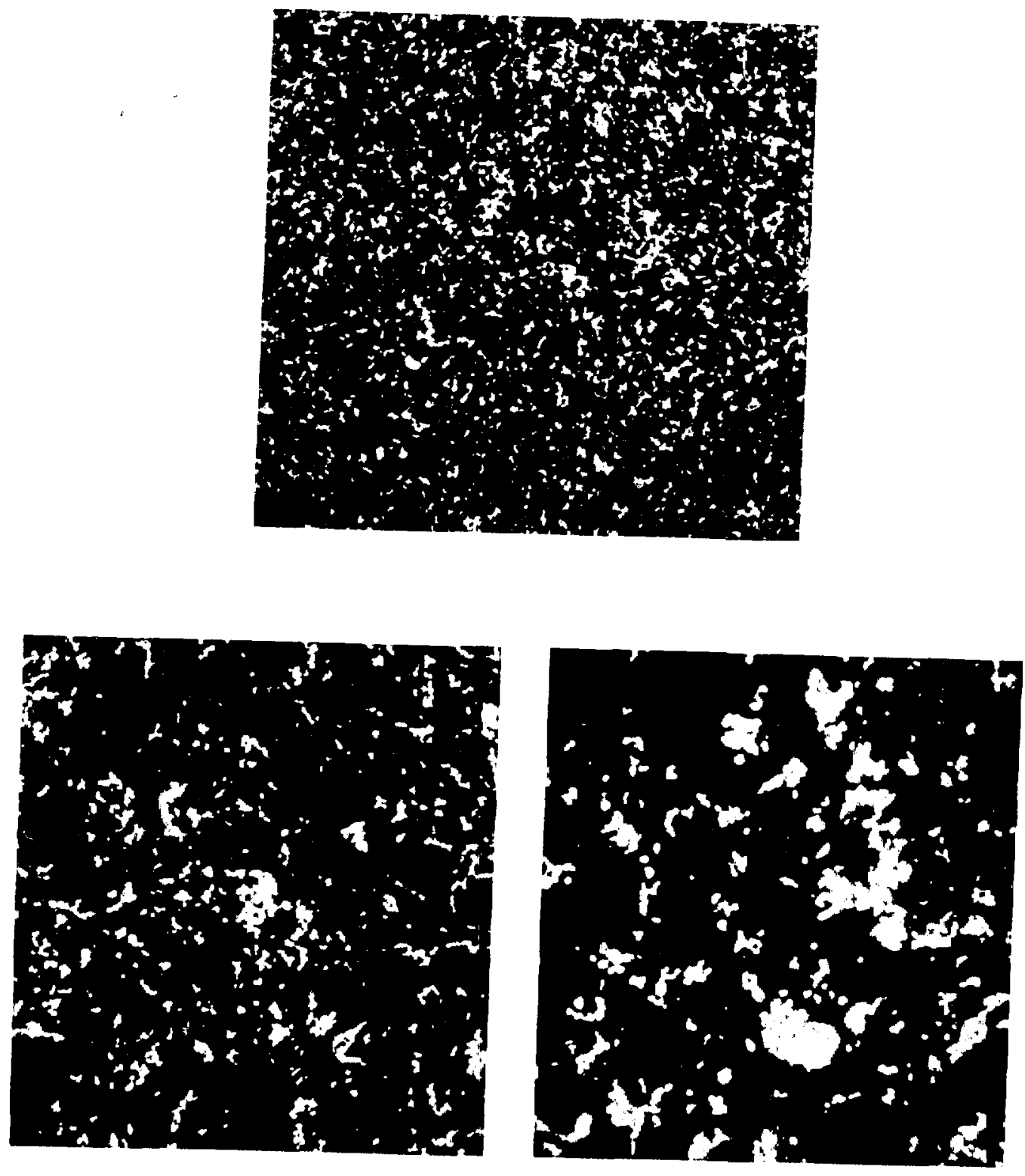
F1g. 25. Structure of $40 \mathrm{wt}(10 \mathrm{vol})$ Tac $(0.13 \mu \mathrm{m})$-carbon composite. (Scanning electron micrographs.
Top, 100X. Bottom left, $300 \mathrm{x}$. Bottom rilght, 500X.) 

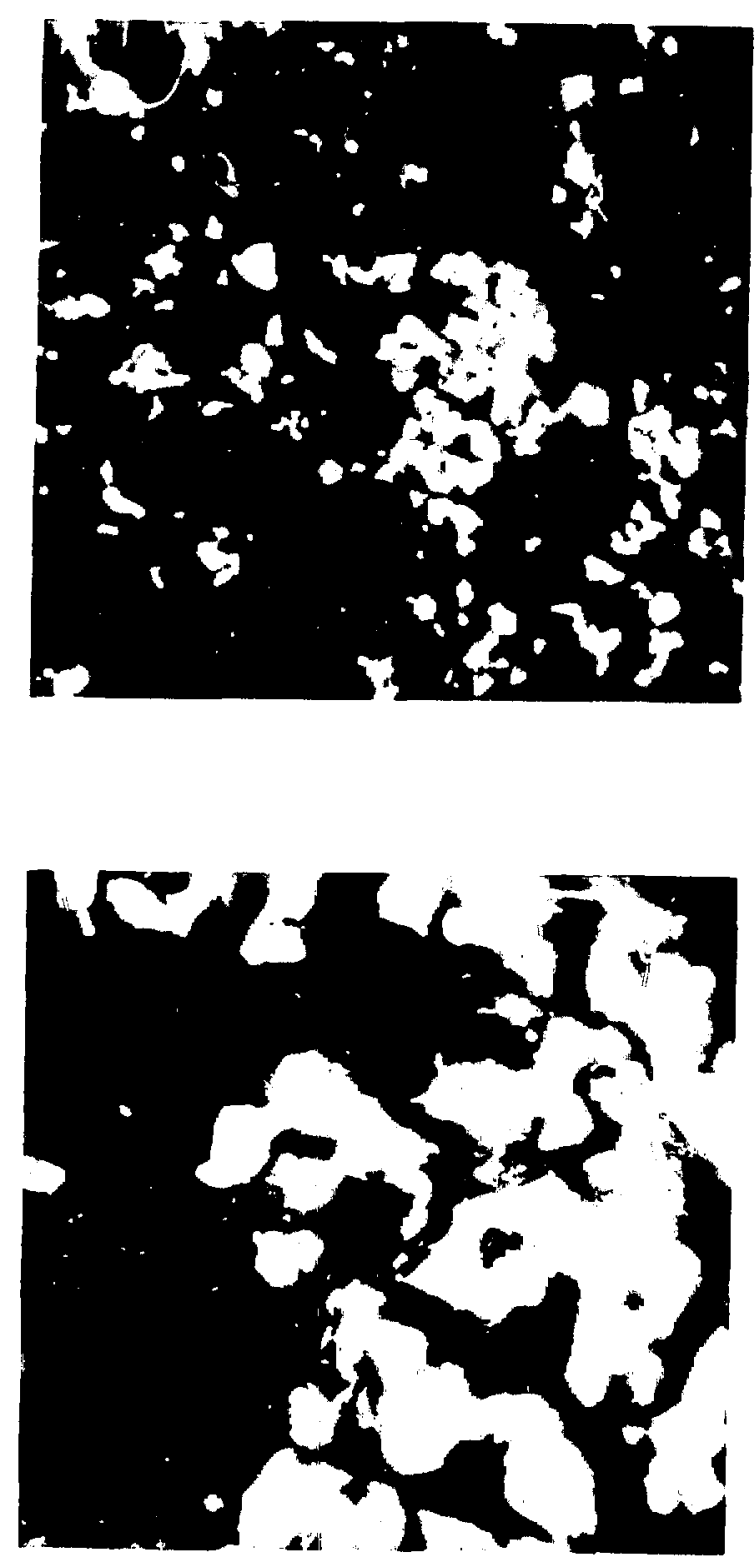

F1g. 26. Structure of $40 \mathrm{wt}(10 \mathrm{volq)}) \mathrm{TaC}(0.13 \mu \mathrm{m})$-carbon composite. (Scanning electron mlcrographs.
Top, $1000 \mathrm{x}$. Bottom, $3000 \mathrm{x}$.) 

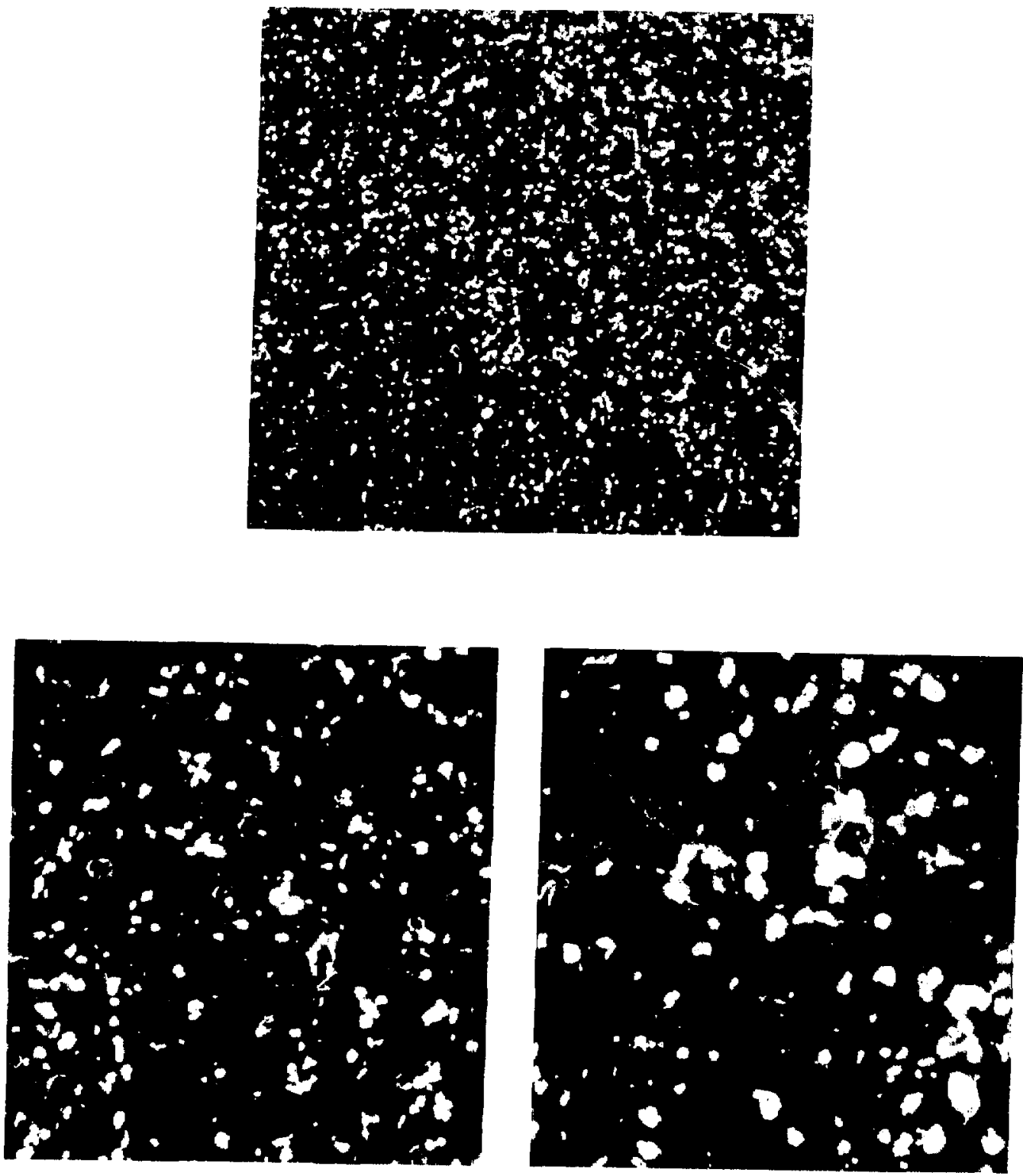

F1g. 27. Structure of $40 \mathrm{wt}(10 \mathrm{vol})$ Tac $(4.2 \mu \mathrm{m})$-carbon composite. (Scenning electron micrographs, Top, 100x. Bottom left, 300x. Bottom right, 500x.) 

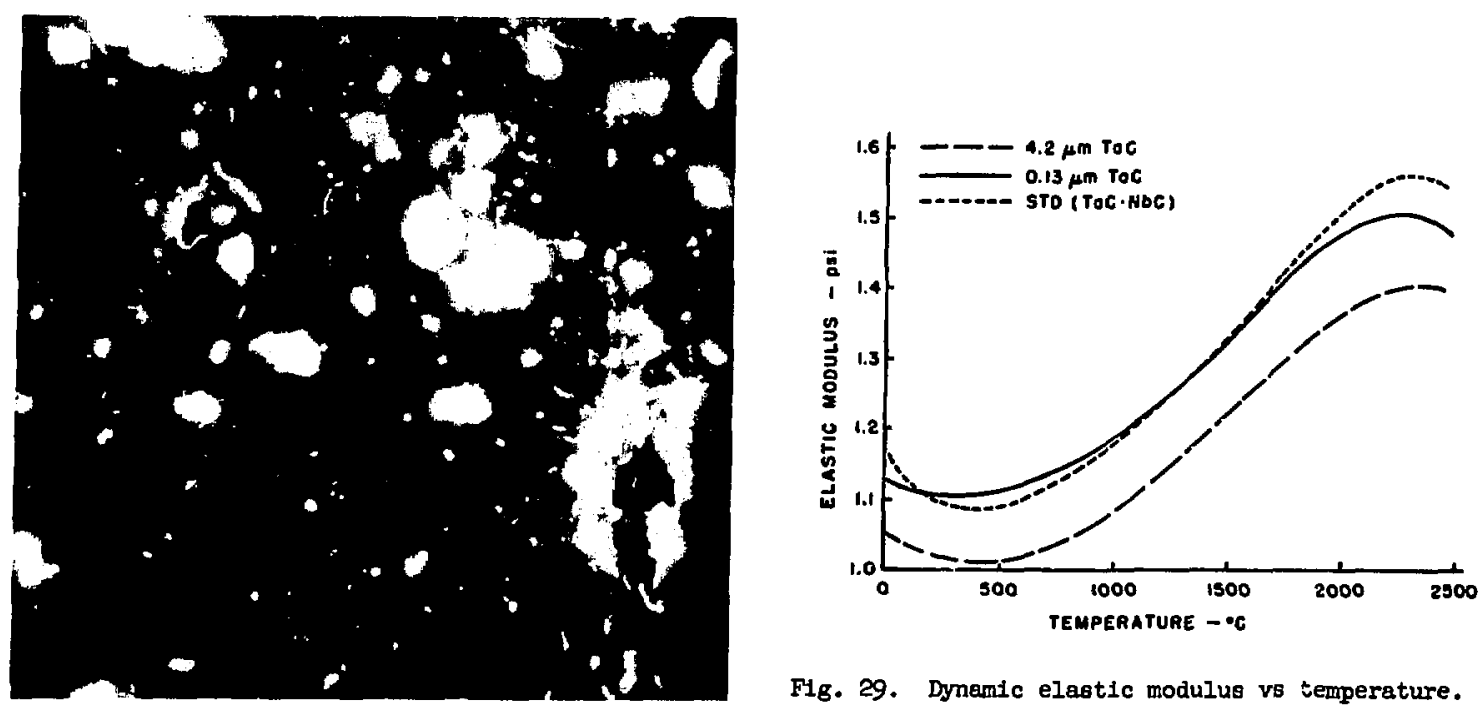

Fig. 29. Dynamic elastic modulus vs temperature.
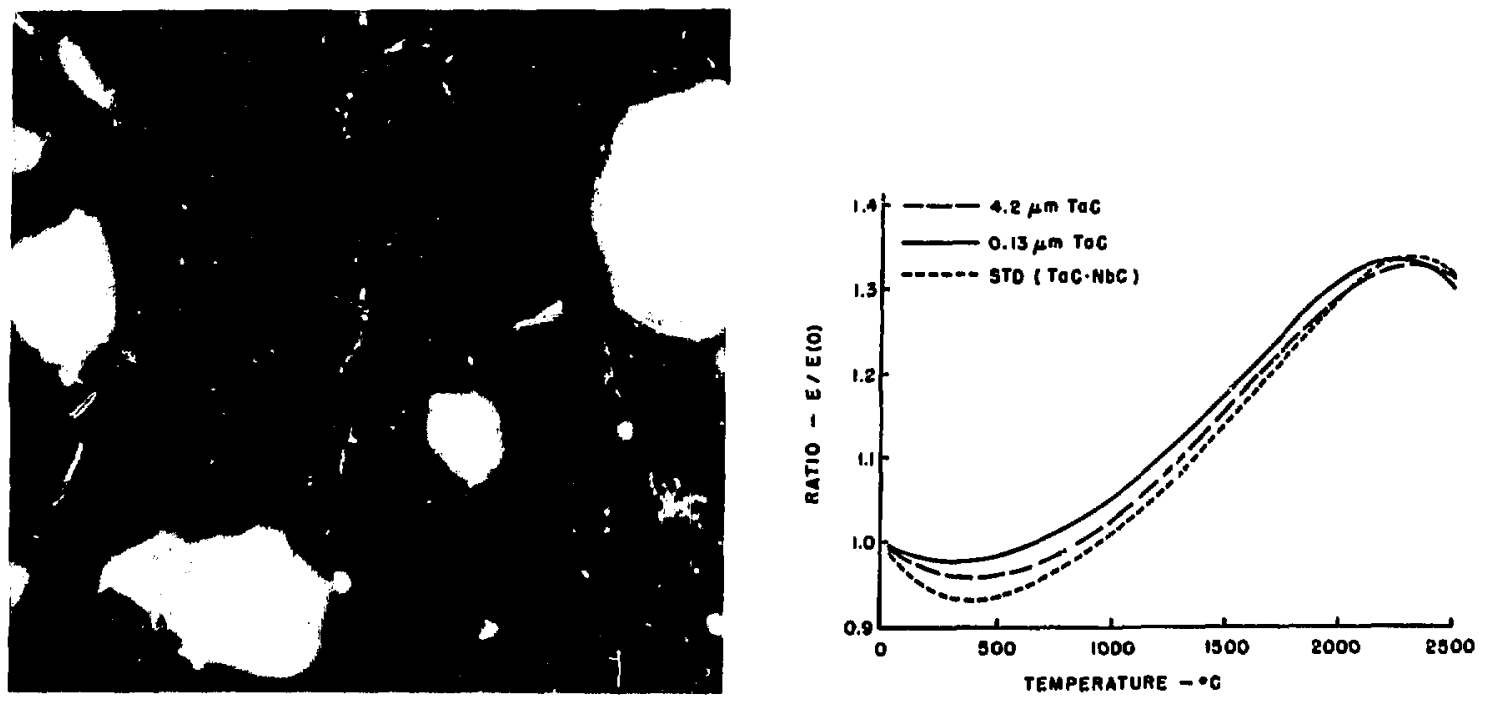

F1g. 28. Structure of $40 \mathrm{wt} \%(10$ vol\%) TaC $(4.2 \mu \mathrm{m})-$ cerbon composite. (Scanning electron micrographs. Top, 1000X. Bottom, 3000K.)

Fig. 30. Reduced elastic modulus. 


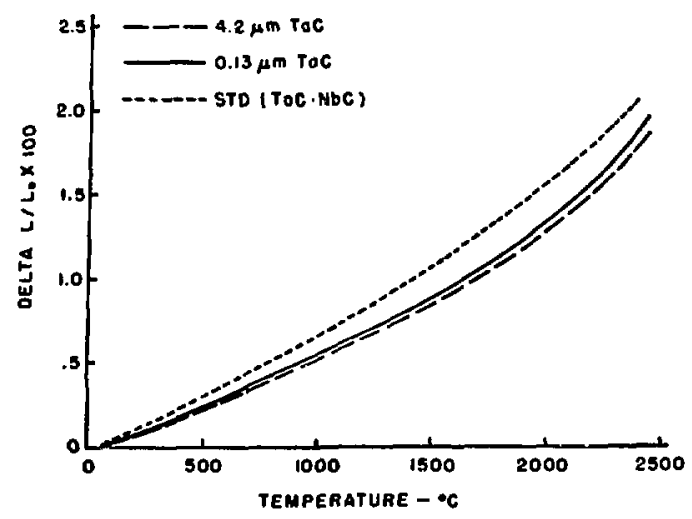

Flg. 3... Thermel expension vs temperature.

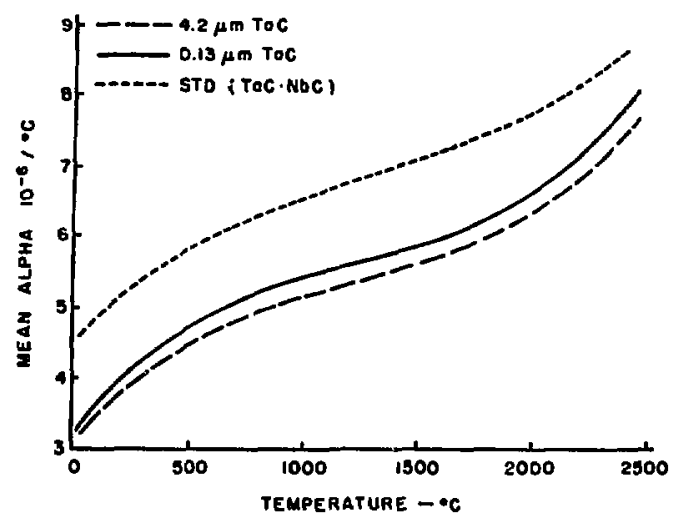

Fig. 32. Mean coefficient of thermal expansion.

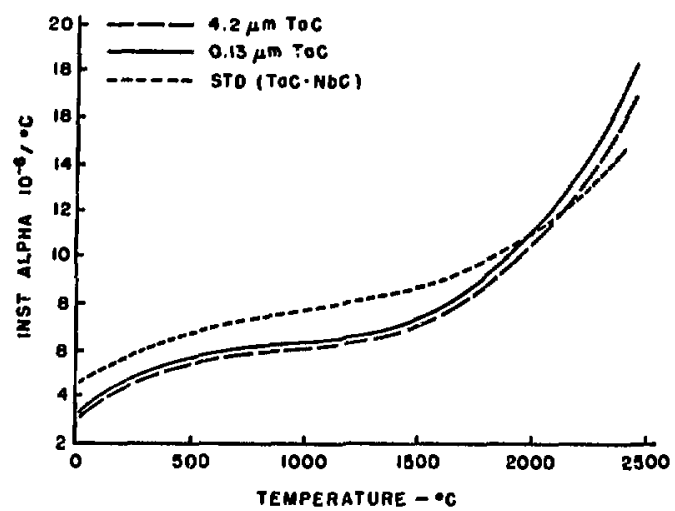

Fig. 33. Invtantaneous coefficient of themal expansion.
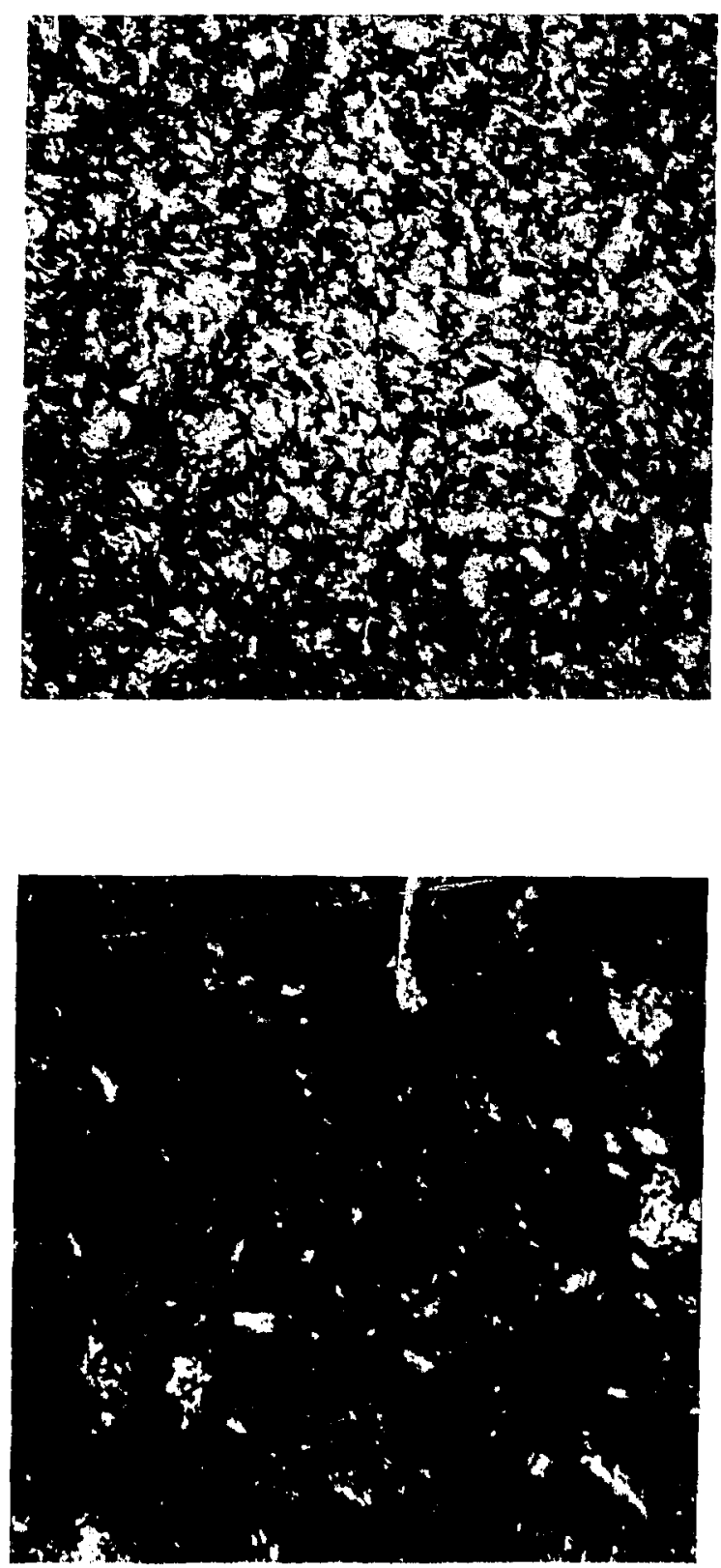

Flg. 34. Microotructure of graphite specimen contuining -325 meoh M-3 graphite. 

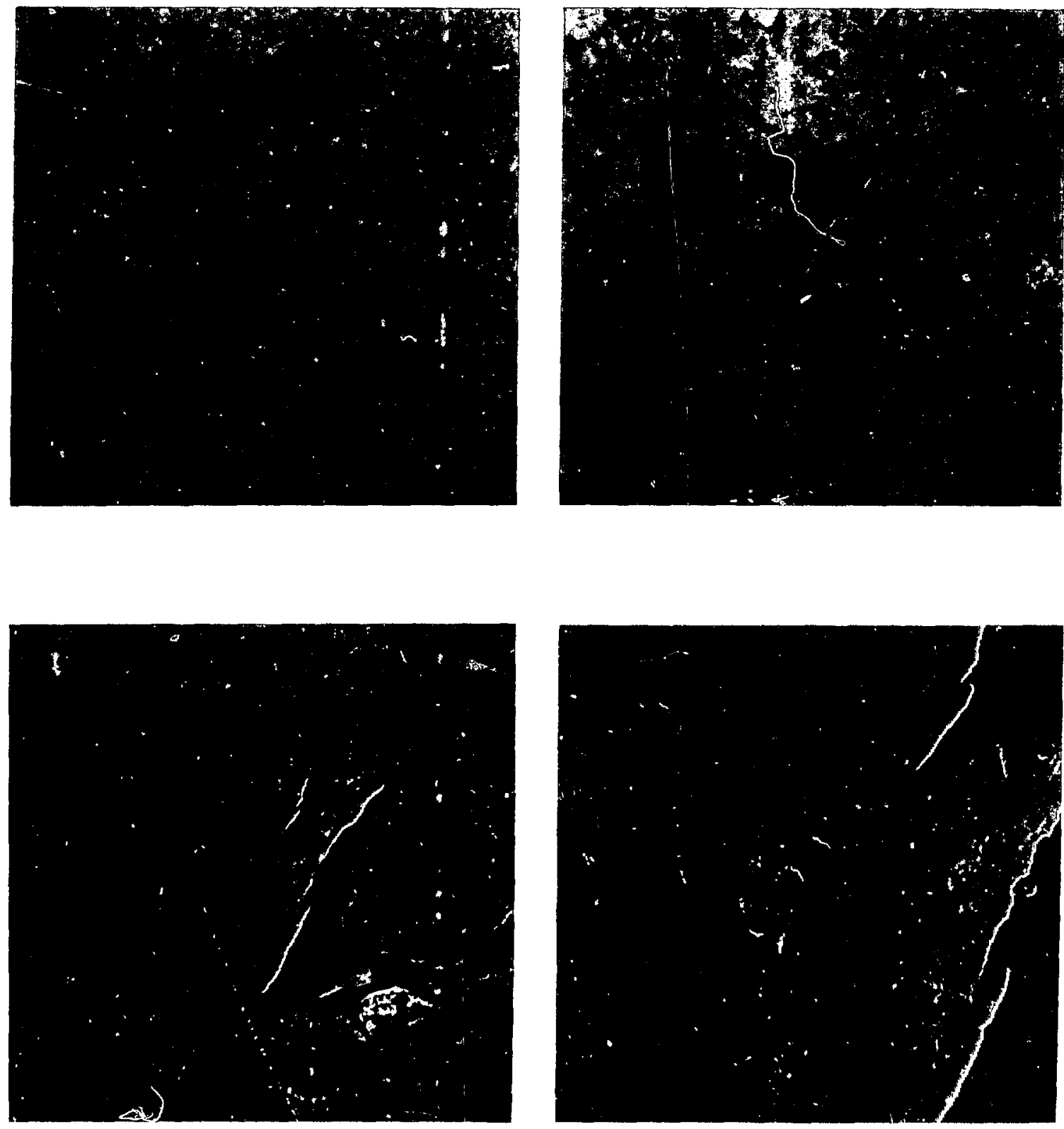

Flg. 35. Microstructure of graphite gample containing - 325 mesh M-3 graphite flour. (Scanning electron mj.crographs. Top left, 100X. Top right, 300X. Bottom jeft, 1000x. Bottom right, 3000x.! 

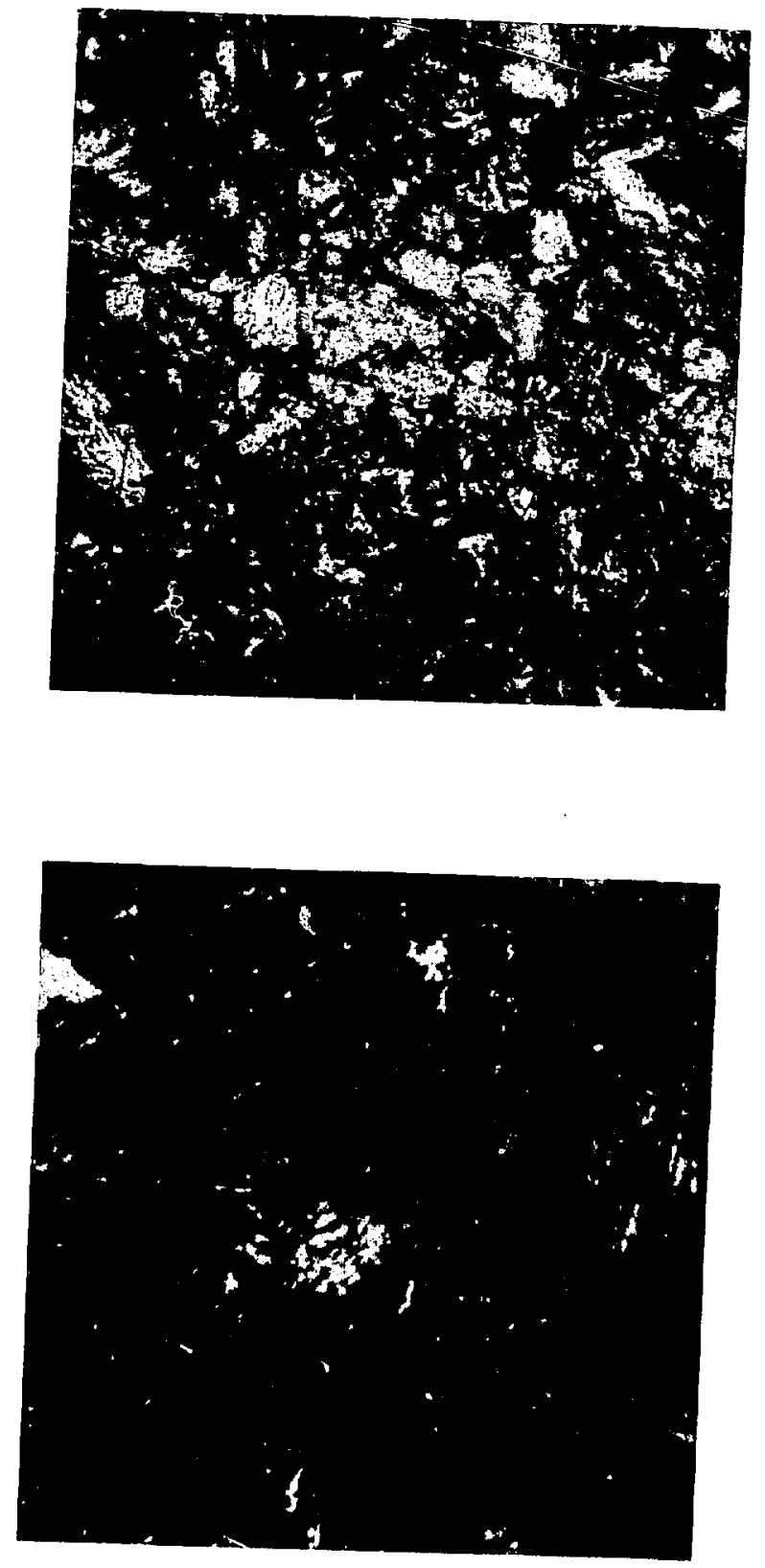

F18. 36. Microstructure of graphite specimen containing $85 \mathrm{wtg} M-3$ graphite flour and 15 wt Thermax.
(Conventional metallography. Top, $100 x$. Bottom, 500x.) 

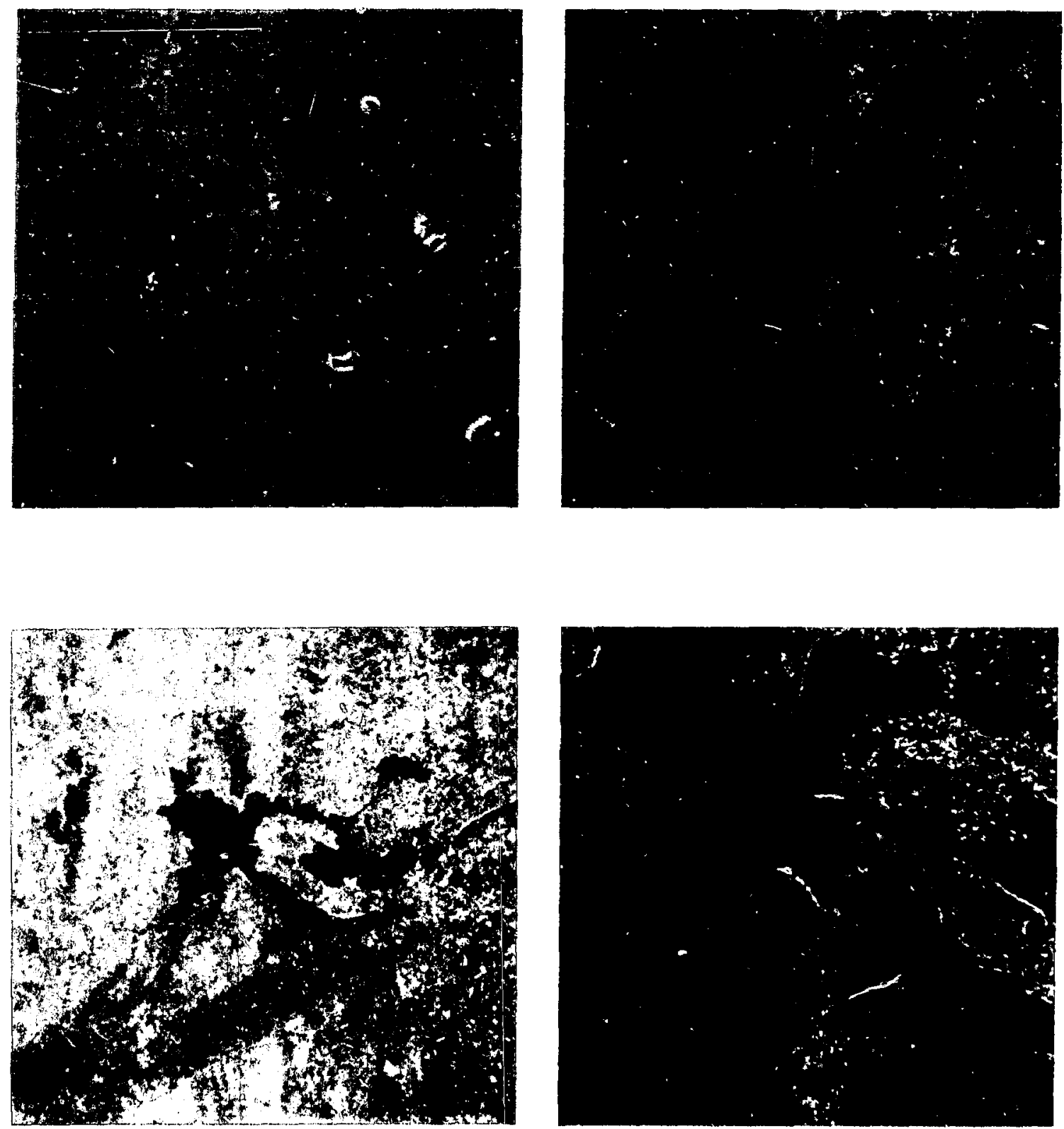

FLg. 37. Microstructure of graphite sample contalning 85 wt\$ M-3 graphite four and 15 wt (Scenning electron micrographs. Top left, 100x. Top right, 300x. Bottom left, 1000X. Bottom right, 3000x.) 

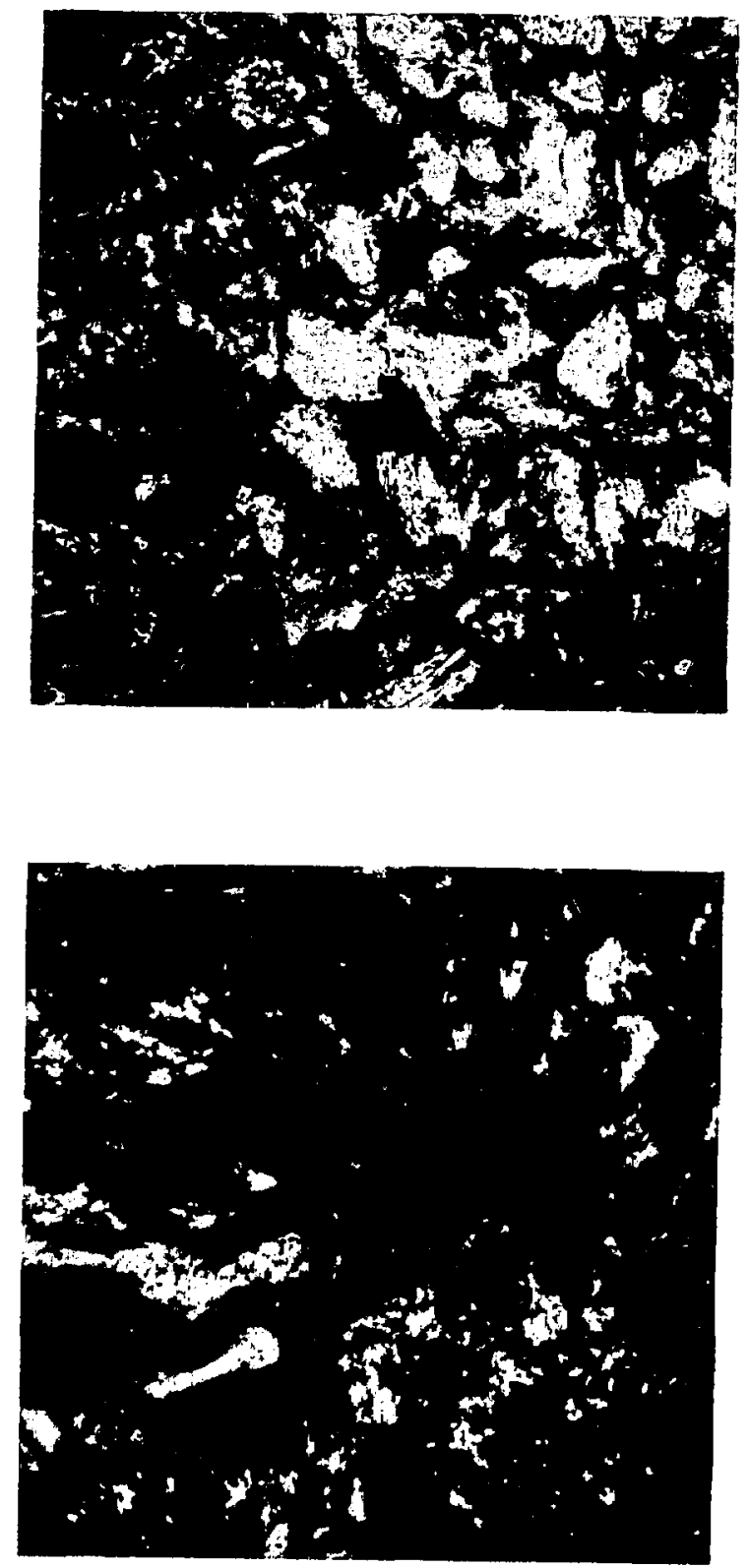
Fig. 38. Microstructure of graphite specimen containing $-150+325$ meah M-3 graphite flour. (Conventional
metallography. Top, 100x. Bottom, 500X.) 

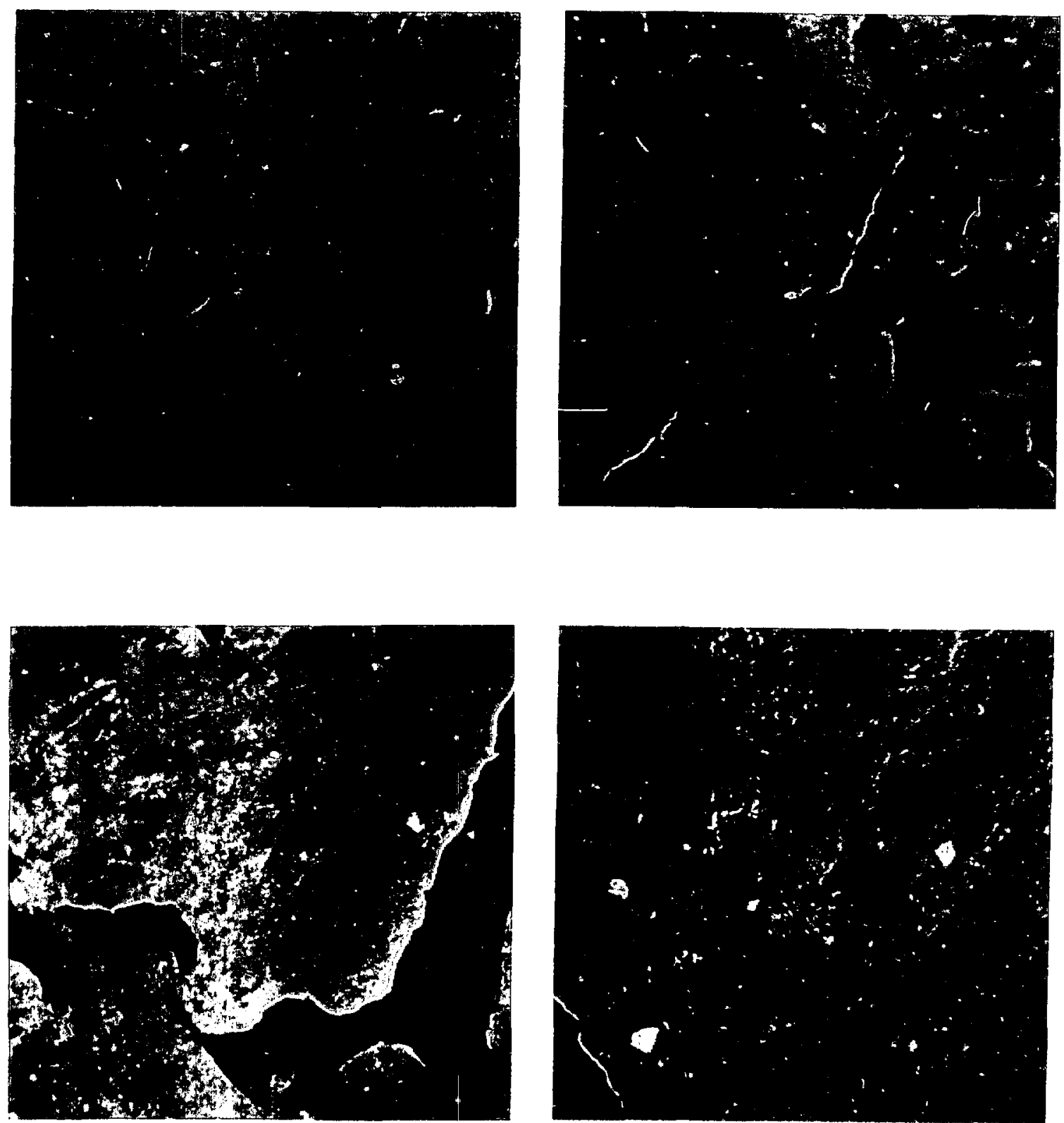

F1g. 39. Microstructure of graphite sample containing $-150+325$ mesh M-3 graphite flour. (Scanning electron m1crographs. Top left, 100x. Top rilght, 300x. Bottom left, 1000x. Botton right, 3000x.) 

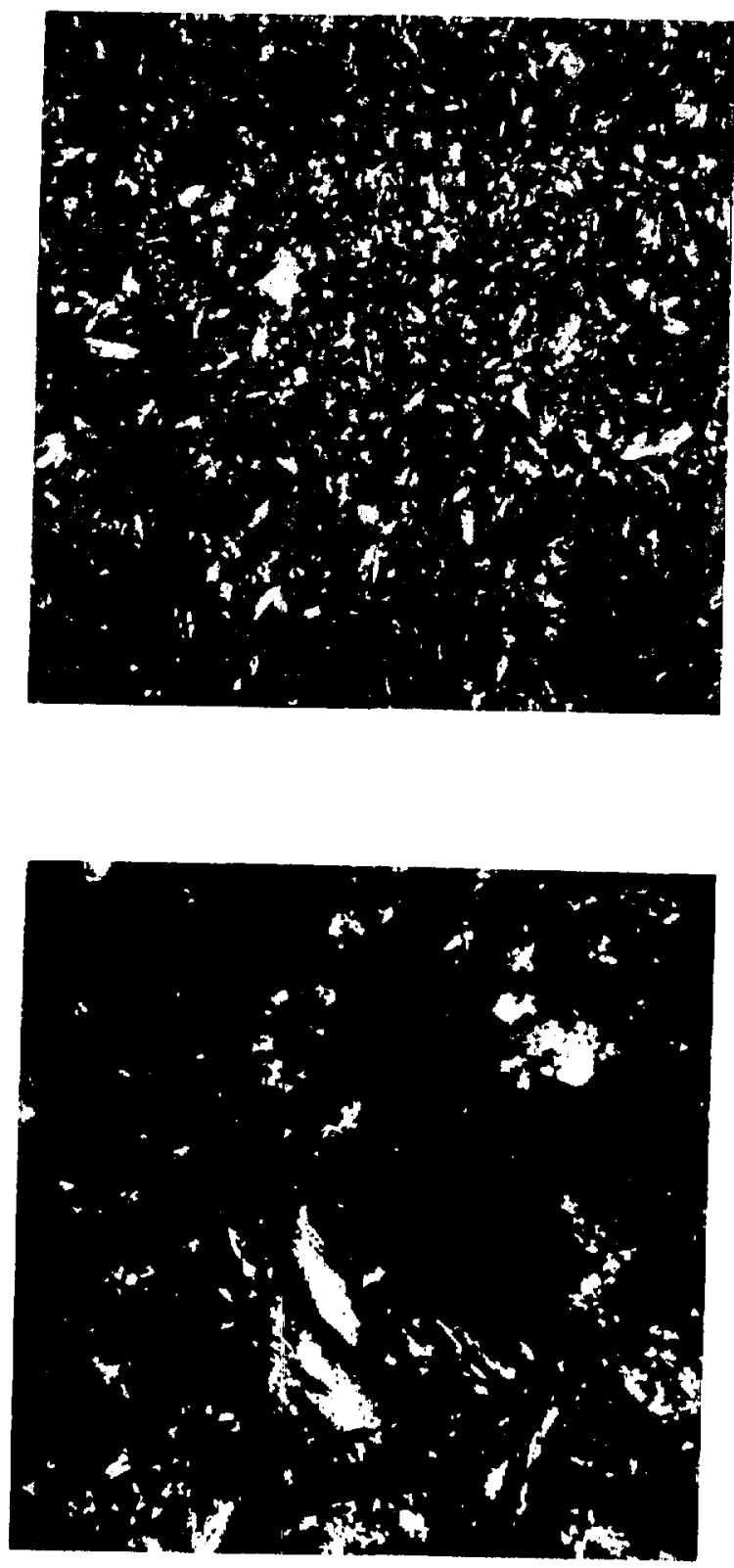

F1g. 40. Microstructure of TaC-C composite containing I wt $300 \AA$ AgC-38. (Conventional metallography.
Top, 100X. Bottom, 500X.) 

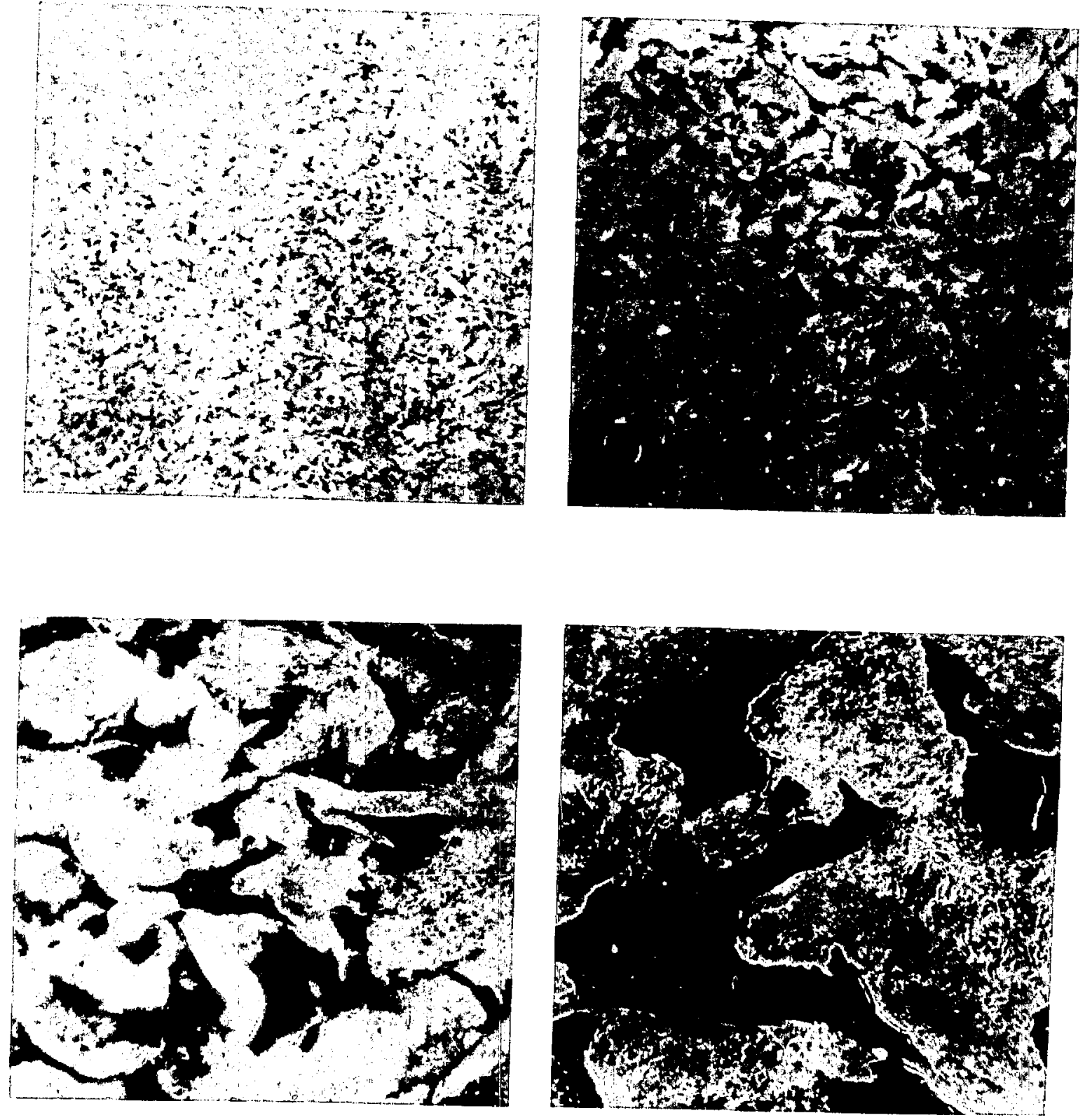
F1g. 41. Microstructure of TaC-C composite containing 1 wt $300 \AA$ TaC-38. (Scanning electron micrographs.
Top left, 100X. Top right, 300X. Bottom left, 1000X. Bottom right, 3000X.) 

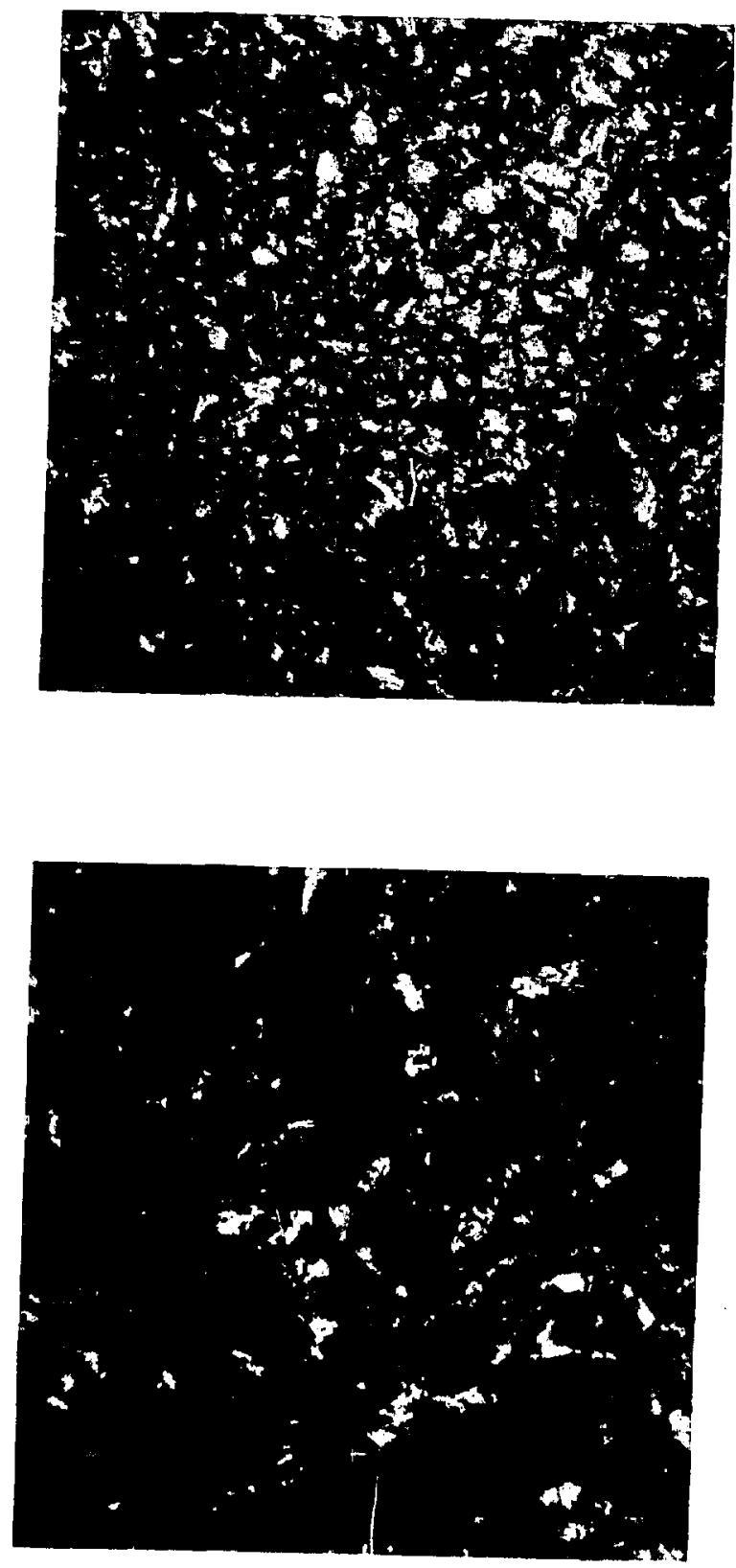

F1g. 42. Microstructure of TaC-C composite containing 5 wto $300 \AA$ A TaC-38. (Conventional metallography.
Top, 100X, Bottom, 500X.) 

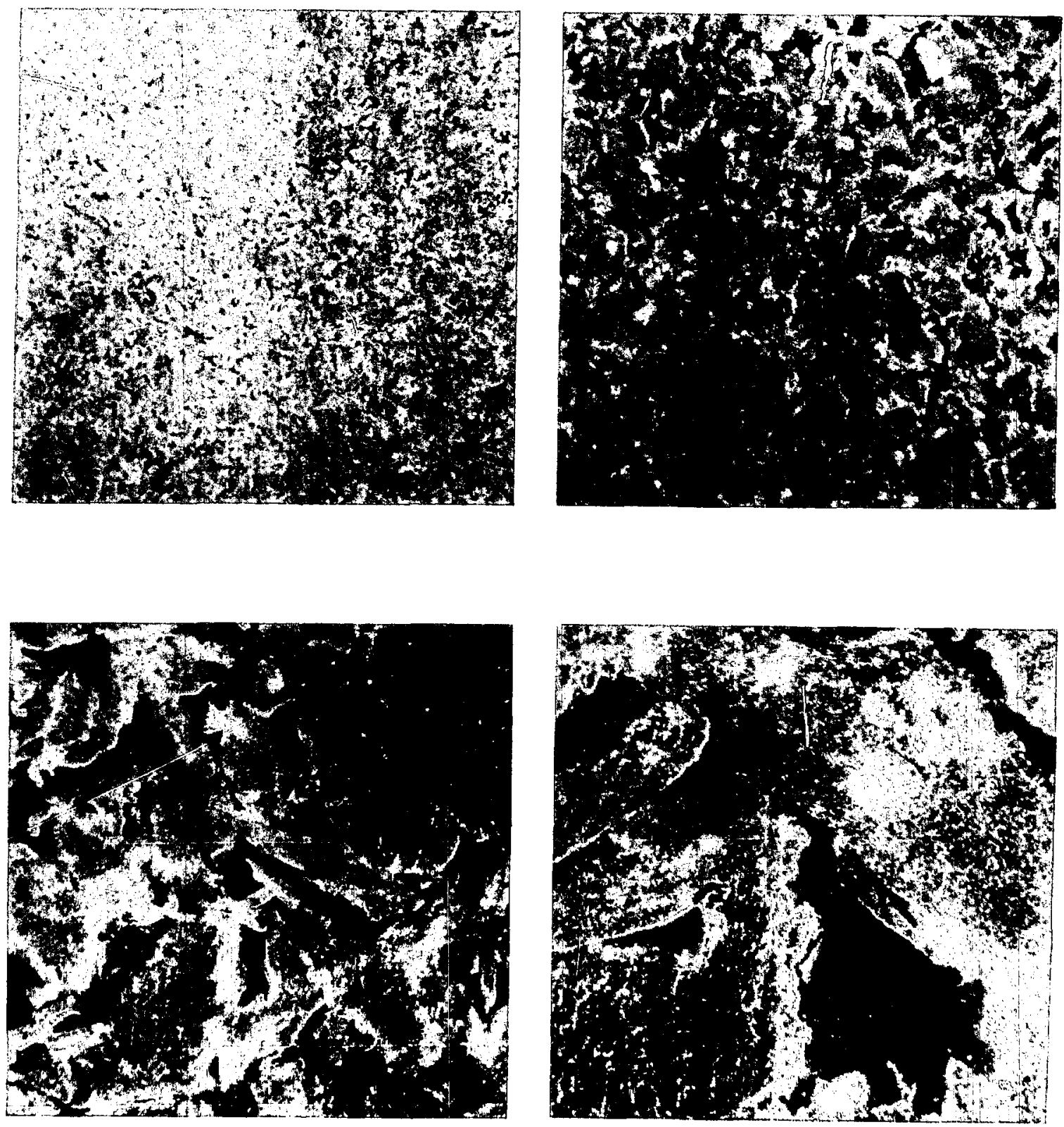

Fig. 43. Microstructure of TaC-C composite containing 5 wt $300 \AA$ TaC-34. (Scanning electron micrographs. Top left, 100X. Top right, 300x. Bottom left, 1000x. Bottom right, 3000X.) 

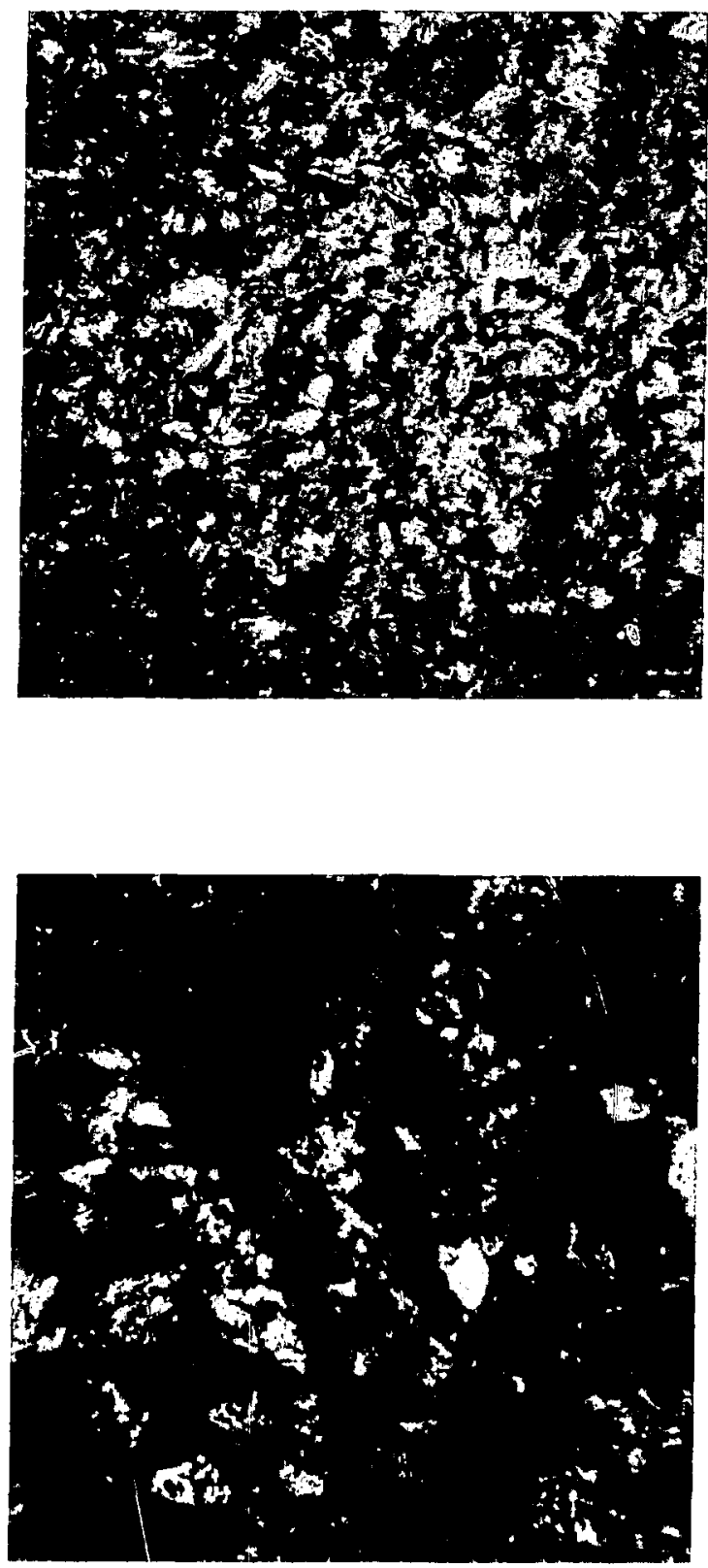

Fig. 44. Microstructure of TaC-C composite containing 7 wt $300 \AA$ TaC-38. (Conventional metellography. Top, 100x. Bottom, 500x.) 

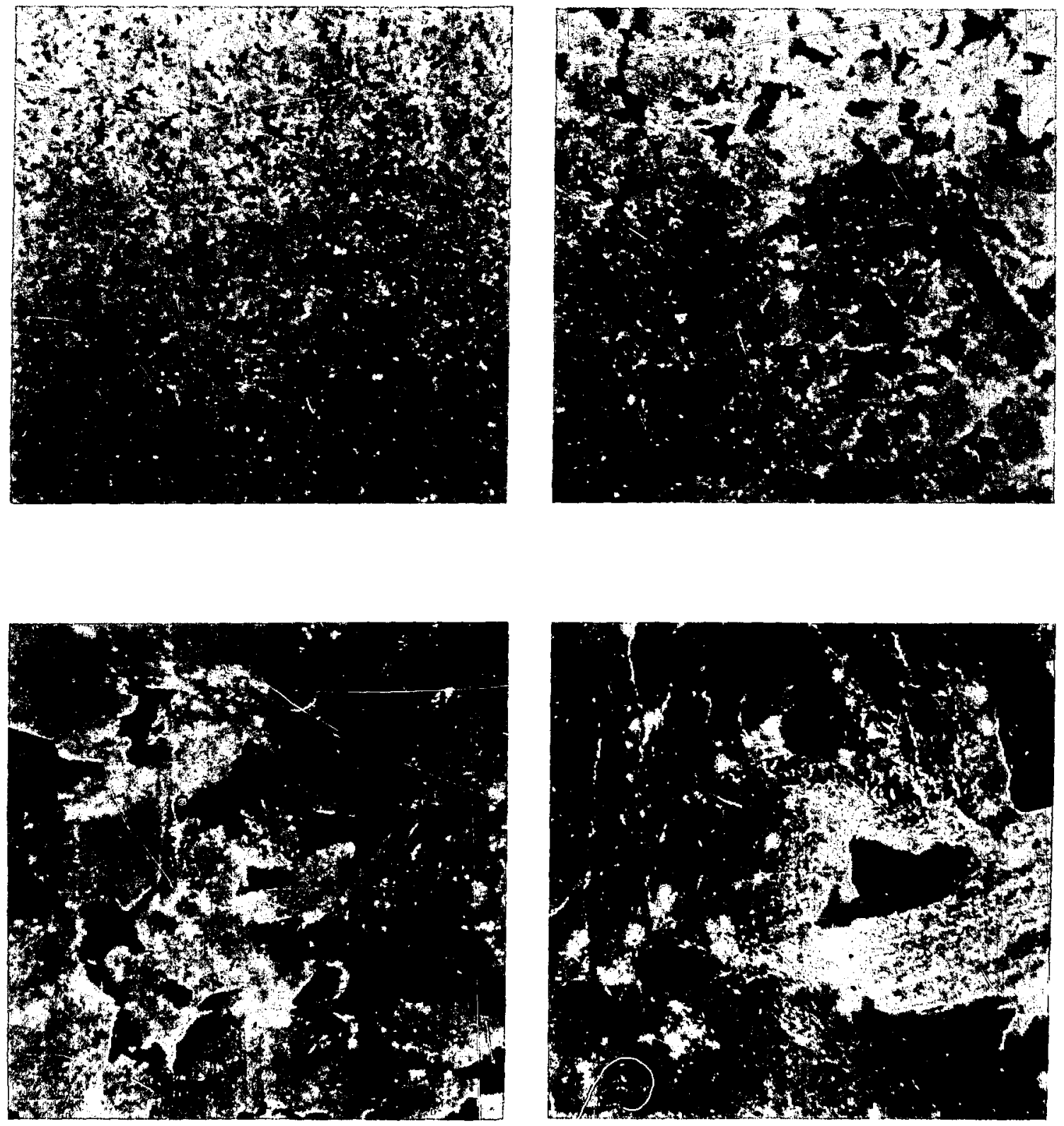

F1g. 45. Microstructure of TeC-C composite contalning 7 wt $300 \AA$ TaC-38. (Scanning electron micrographs. Top left, 100X. Top right, 300X. Bottom left, 1000X. Bottom right, 3000X.) 

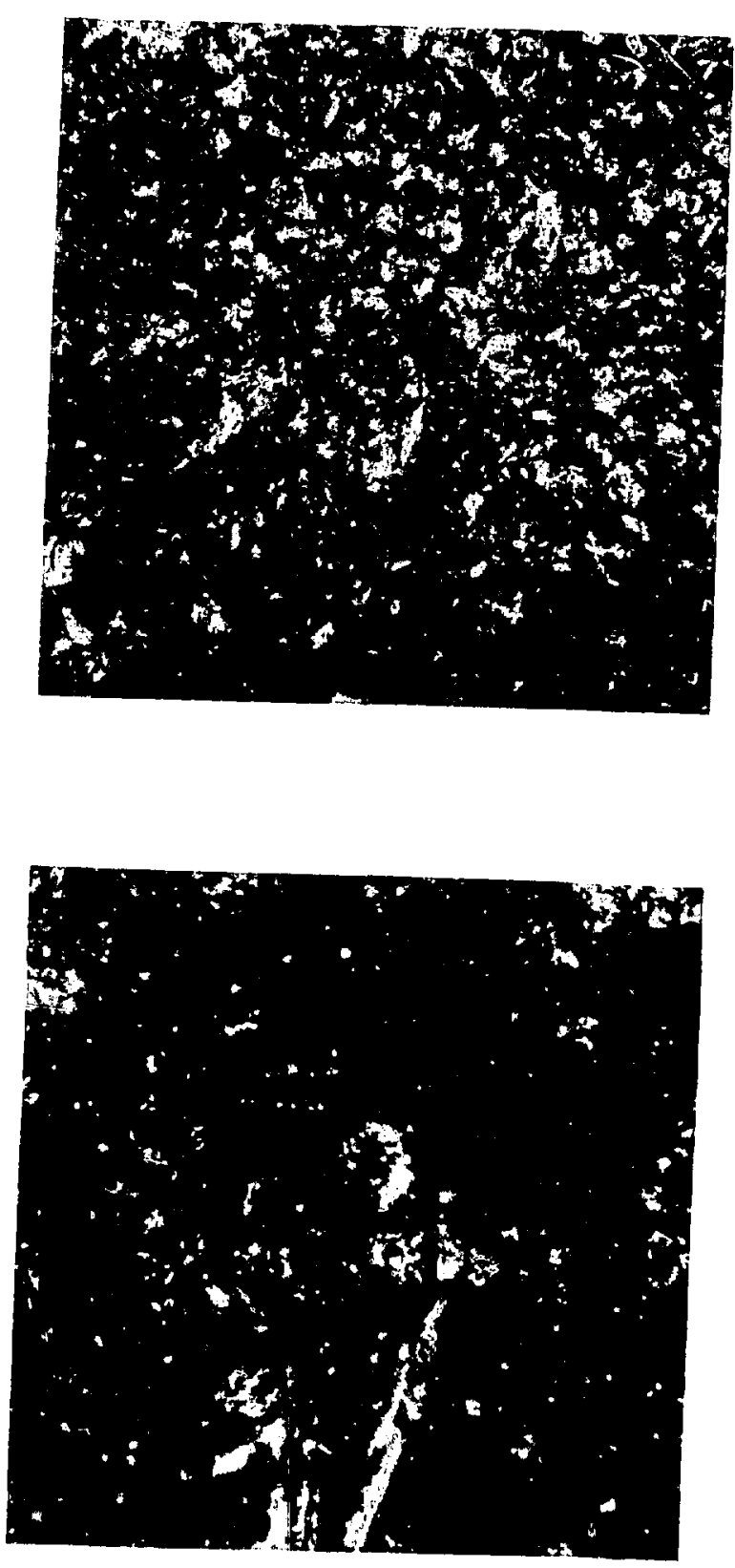

Fig. 46. M1crostructure of TaC-C composite containing 24 wt $300 \AA$ TaC-38. (Conventional metallography.
Top, 100X. Bottom, 500x.) 

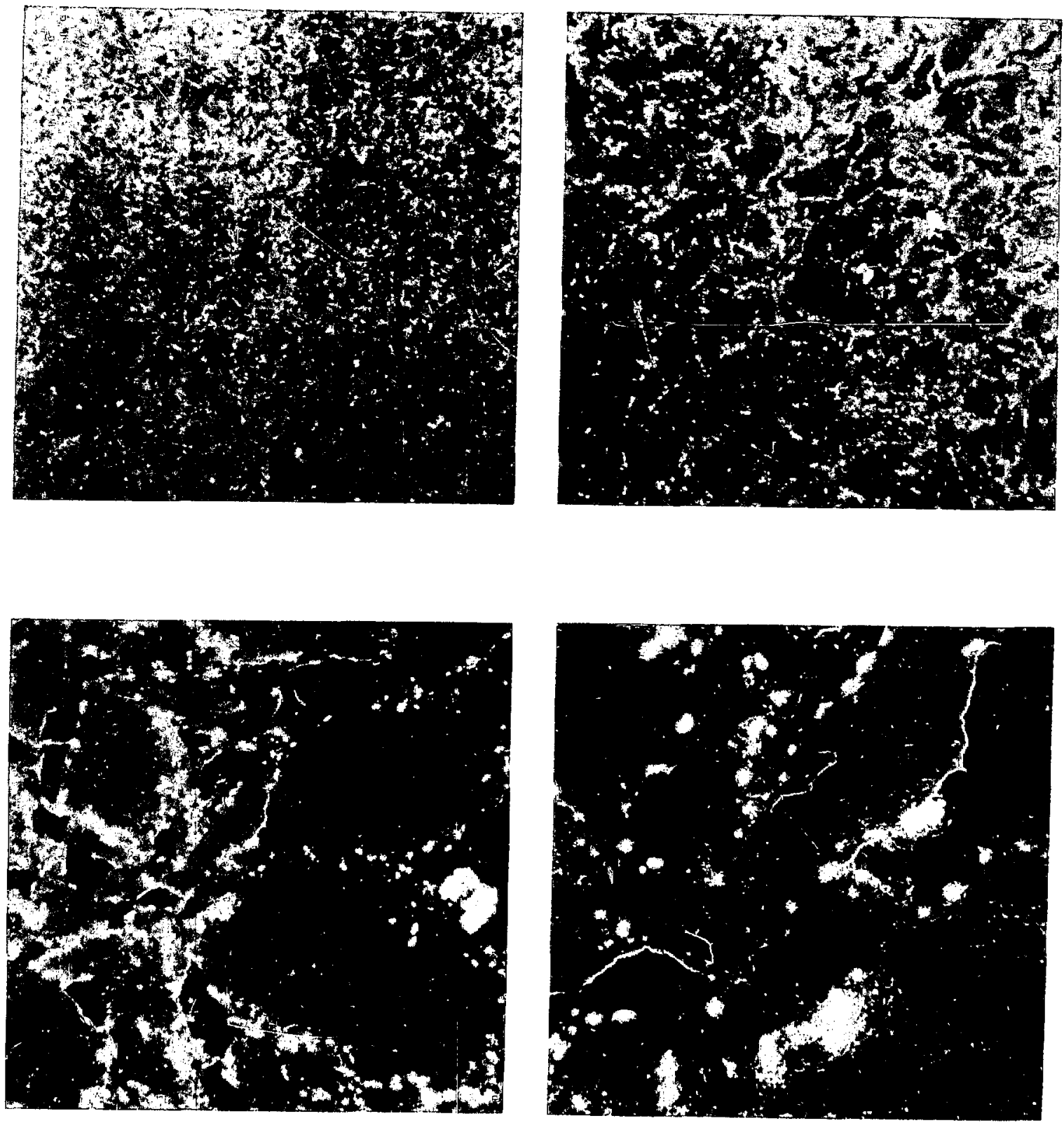

Fig. 47. Microstructure of TaC-C composite containing 14 wtक $300 \AA$ TaC-38. (Scanning electron micrographe, Top left, 100X. Top right, 300x. Bottom left, 1000X. Bottom right, 3000X.) 

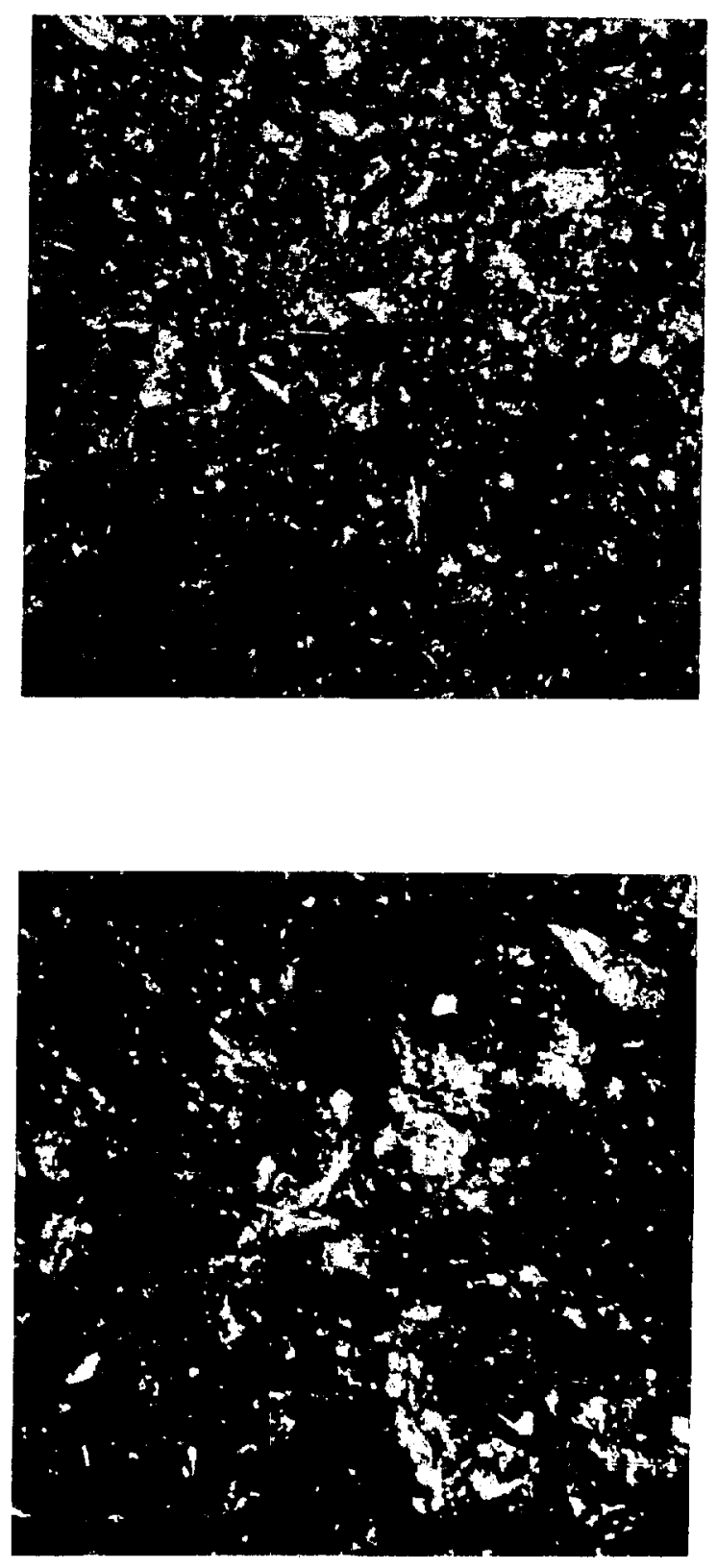

Fig. 48. Microstructure of TaC-C composite containing $20 \mathrm{wt} \% 300 \AA \mathrm{TaC}-36$. (Conventional metallography. Top, 100X. Bottom, 500X.) 

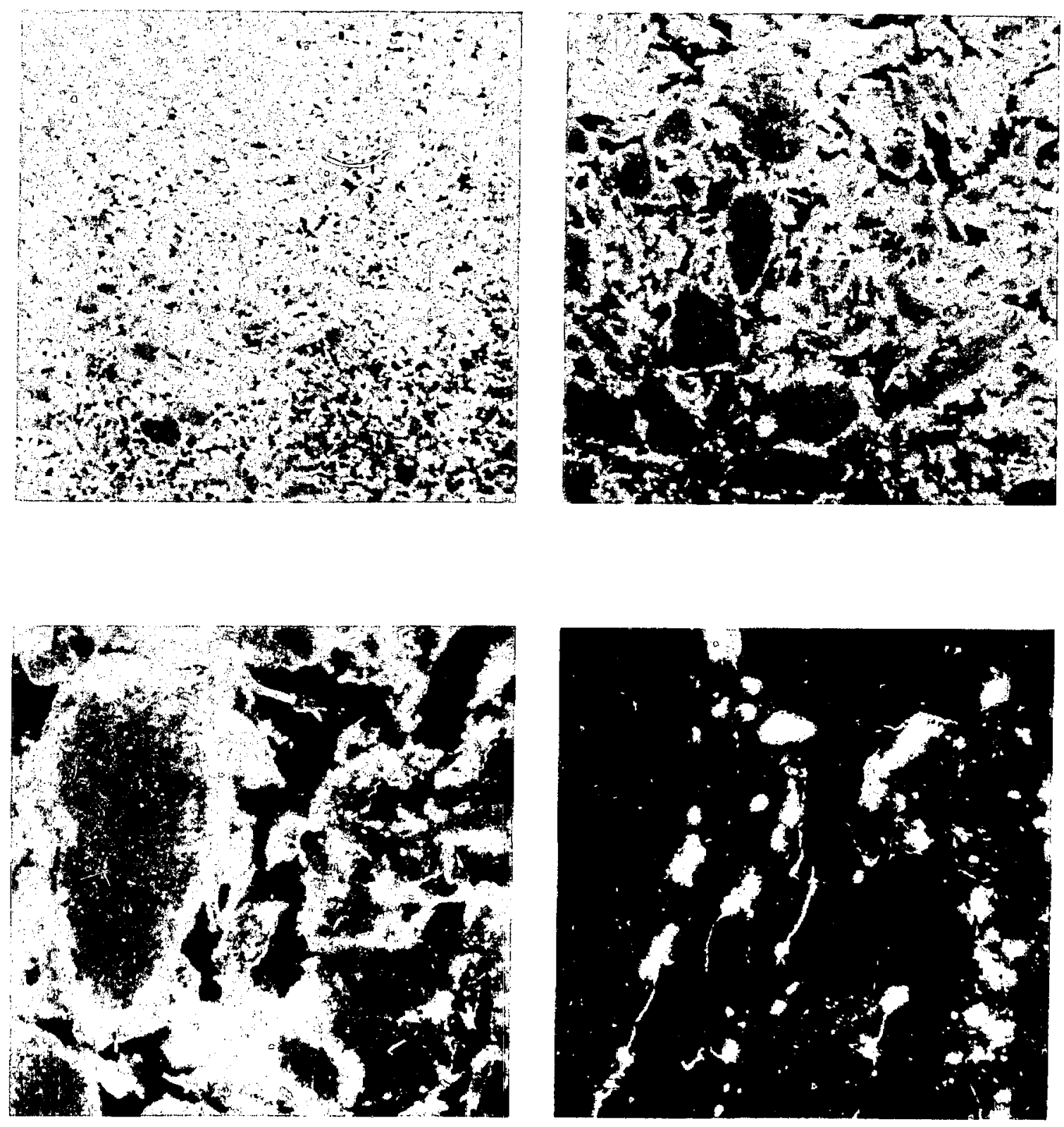

F4g. 49. Microstructure of TaC-C composite conteining 20 wto $300 \AA$ TaC-38. (Scanning electron micrographs. Top left, 100x. Top right, 300x. Botton left, 1000x. Bottom right, 3000x.) 

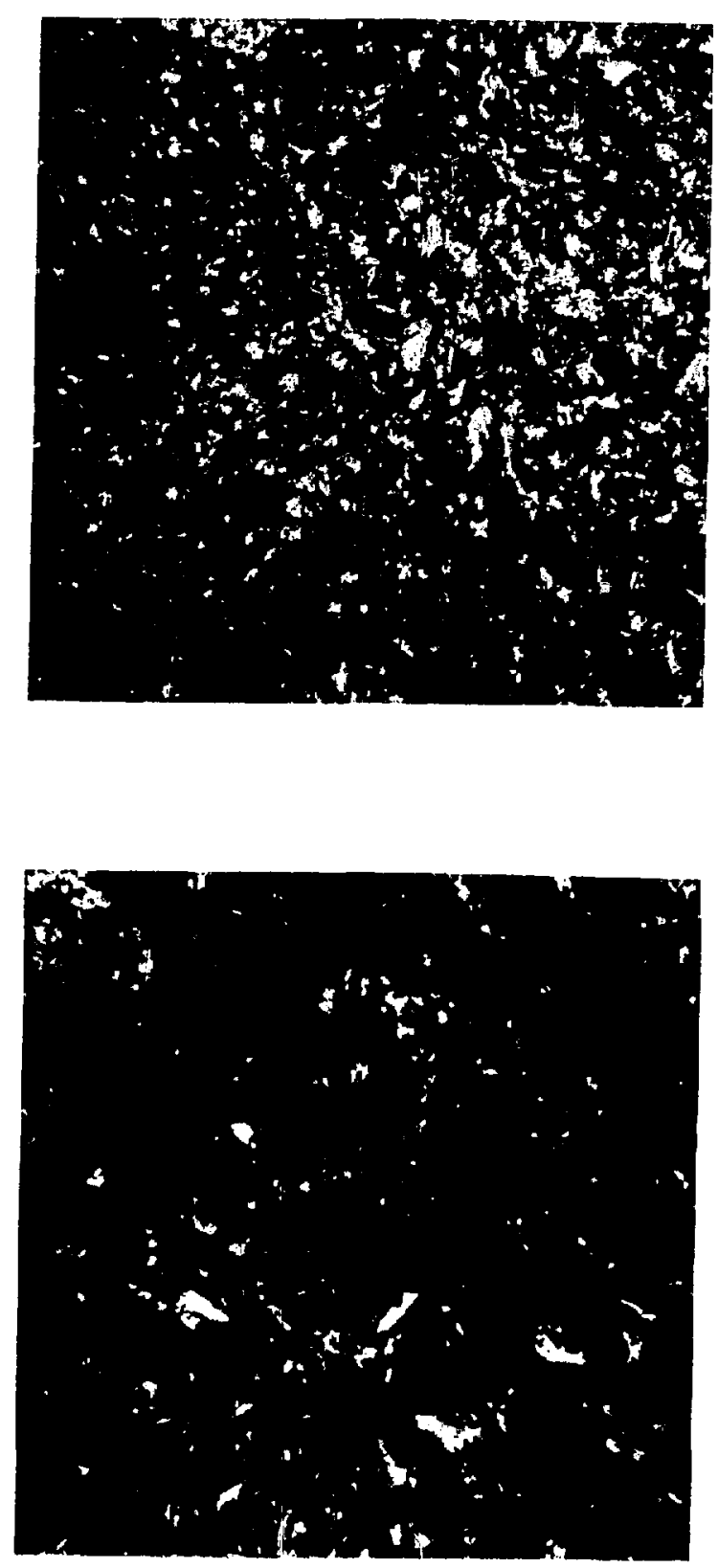

Fig. 50. Microstructure of TaC-C composite containing 1 wt $1.3 \mu \mathrm{mi}$ TaC-30. (Conventional metallography. Top, 100X. Bottom, 500X.) 

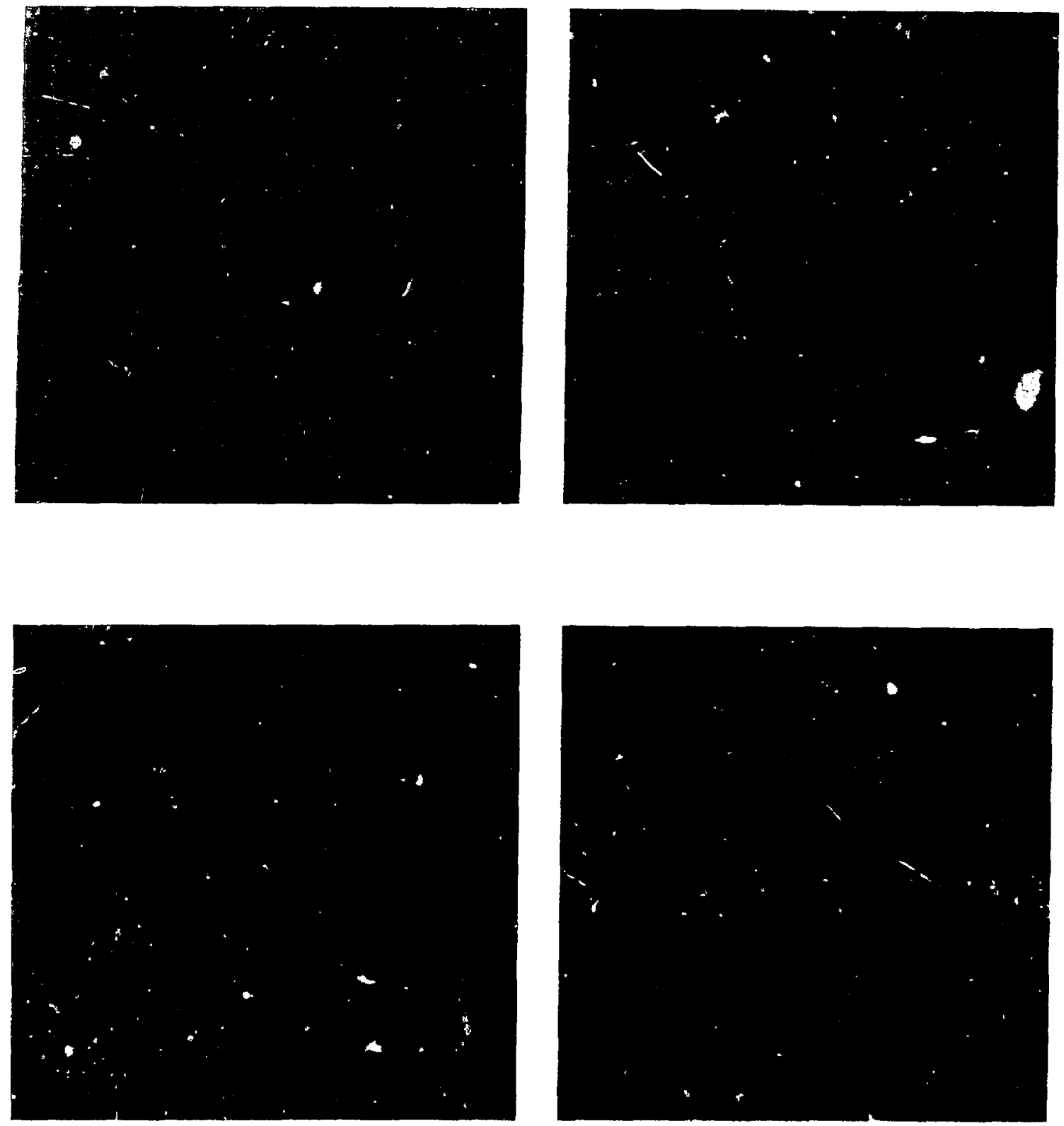

FIg. 51. Microstructure of TaC-C compogite containing 1 th $1.3 \mu \mathrm{m}$ TaC-30. (Scanning electron micrographs, Top left, 100X. Top right, 300x. Botton left, 1000x. Bottom right, 3000x.) 

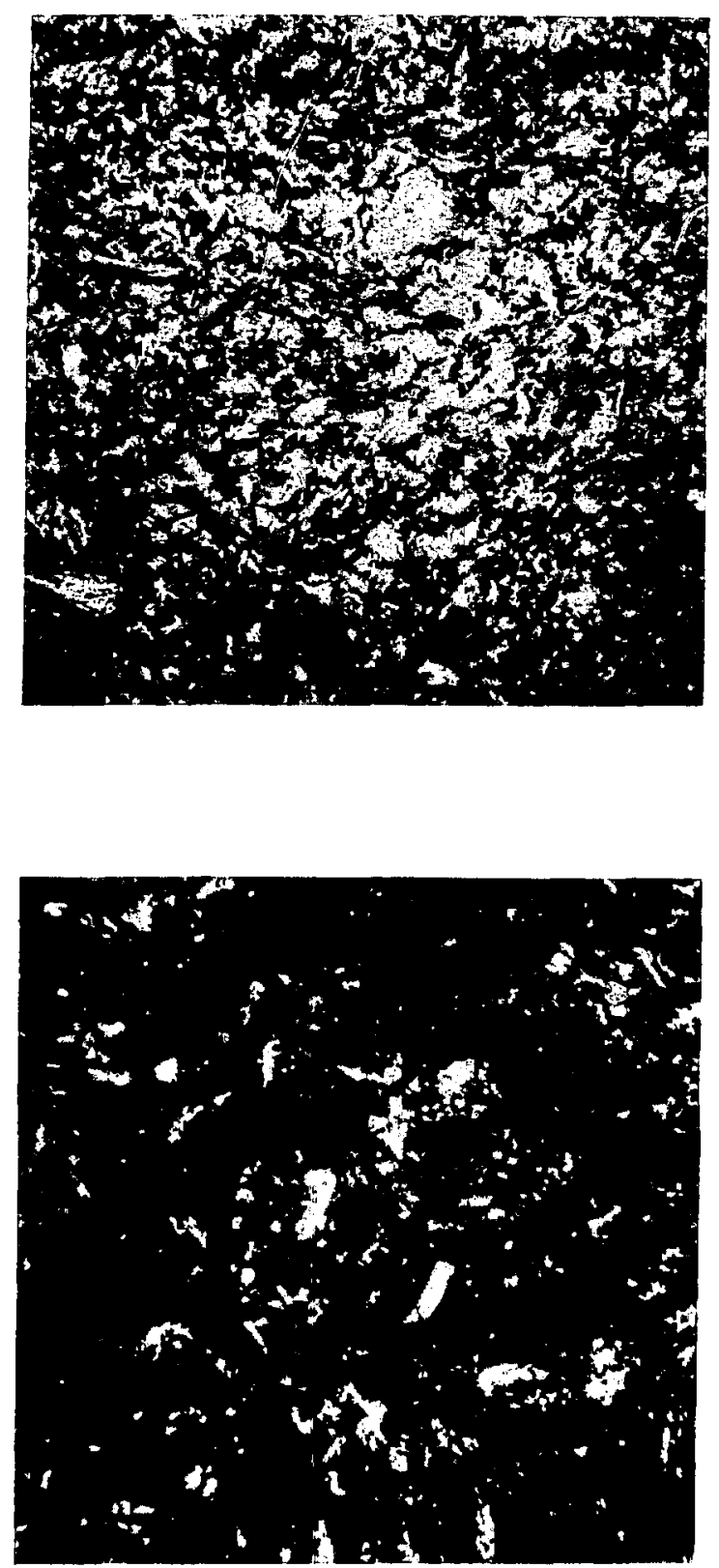

Fig. 52. Microstructure of TaC-C composite containing 5 wt $1.3 \mu \mathrm{m} \mathrm{TaC}-30$. (Conventional metallography. Top, 100x. Bottom, 500x.) 

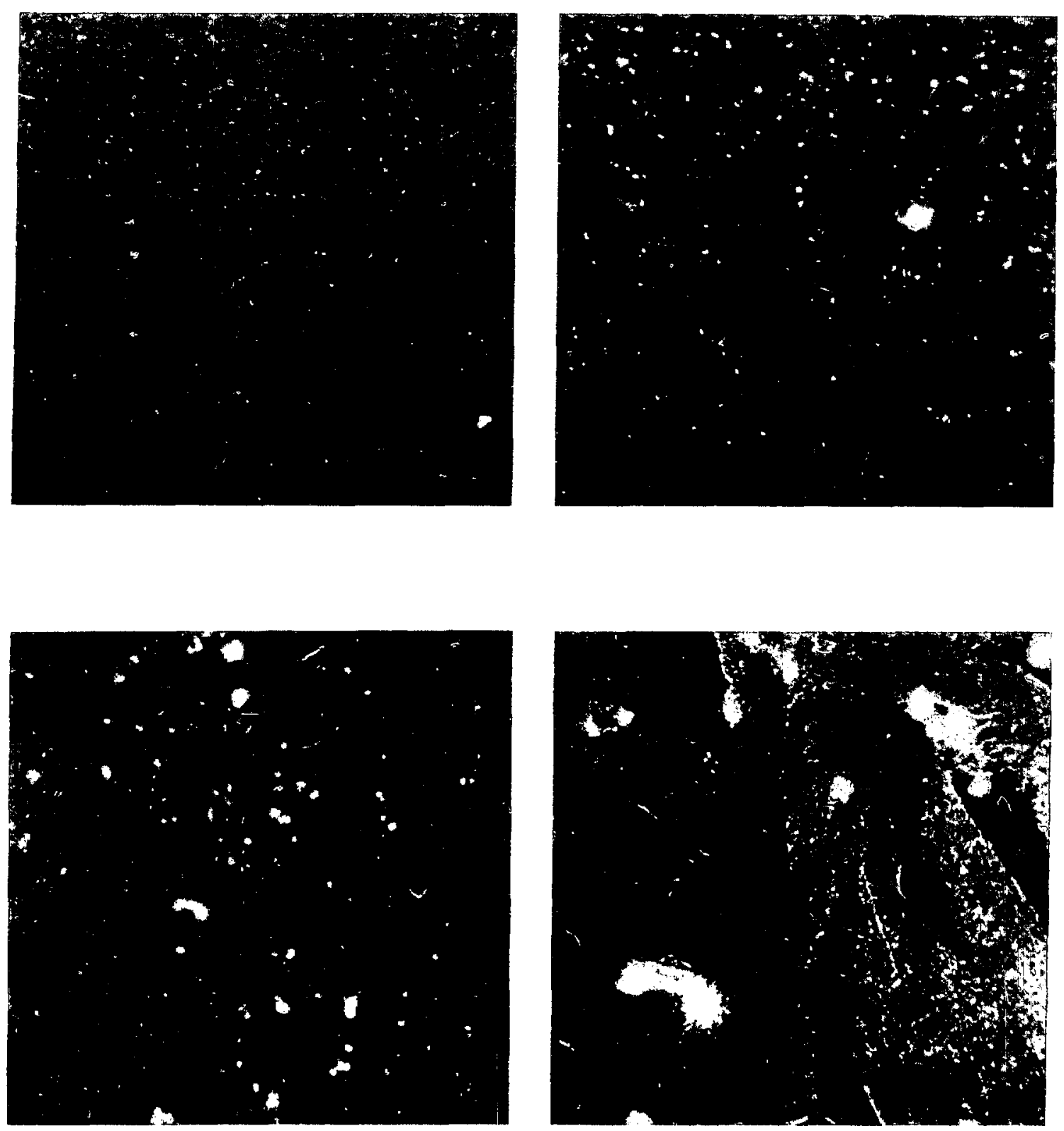

Fig. 53. Microstructure of TeC-C composite contajning 5 wt\% $1.3 \mathrm{\mu m}$ TaC-30. (Scanning electron micrographs. Top left, 100X. Top right, 300X. Bottorn left, 1000X. Botton right, 3000X.) 

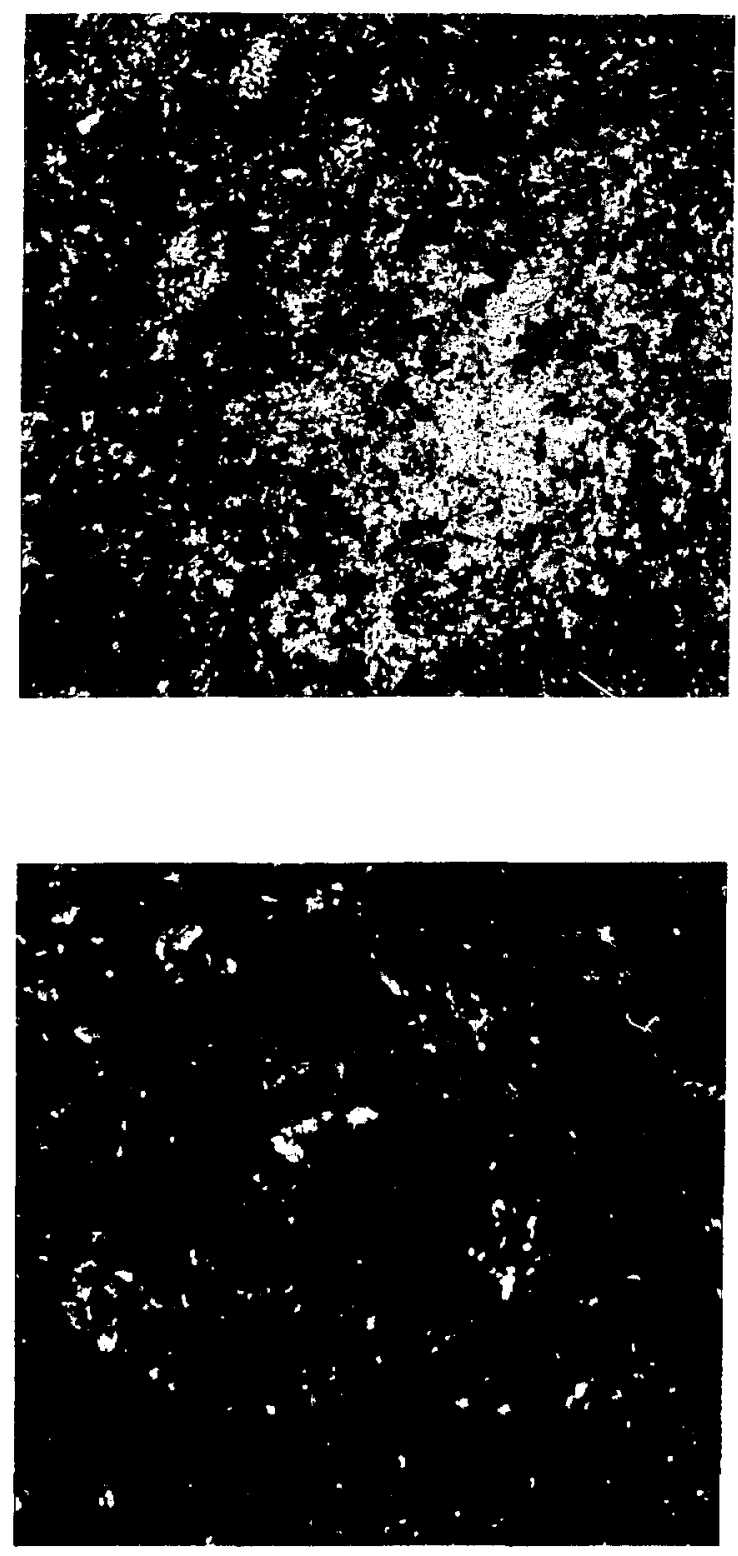

F1g. 54. Microstructure of TaC-C composite containing 7 wt $1.3 \mu \mathrm{m}$ TaC-30. (Conventional metallography. Top, 100X. Bottom, 500X.) 

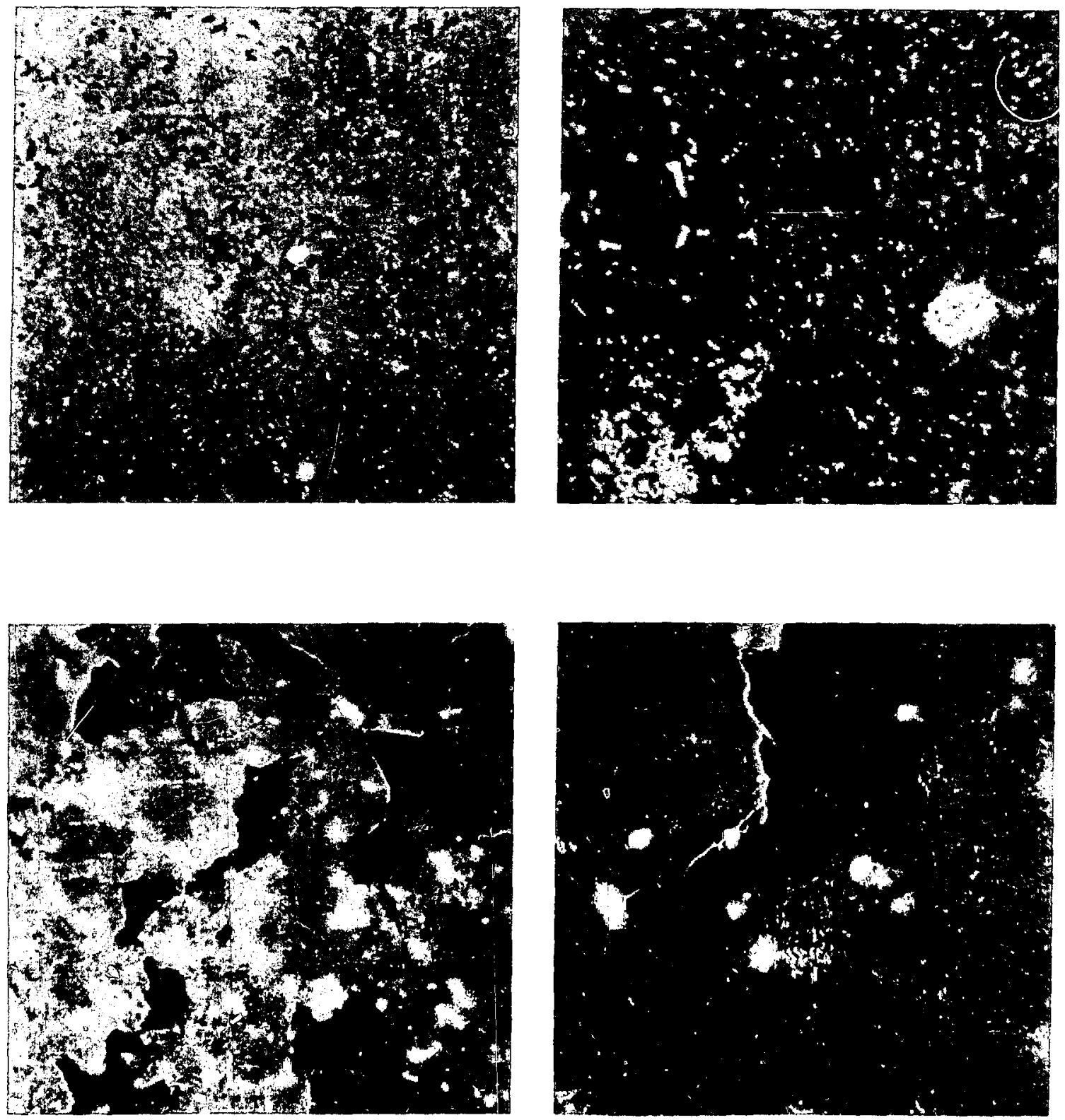

F1g. 55. Microstructure of TaC-C composite containing 7 wt $1.3 \mu \mathrm{m}$ TaC-30. (Scanning electron micrographs. Top left, 100X. Top right, 300x. Bottom left, 1000x. Bottom right, 3000x.) 

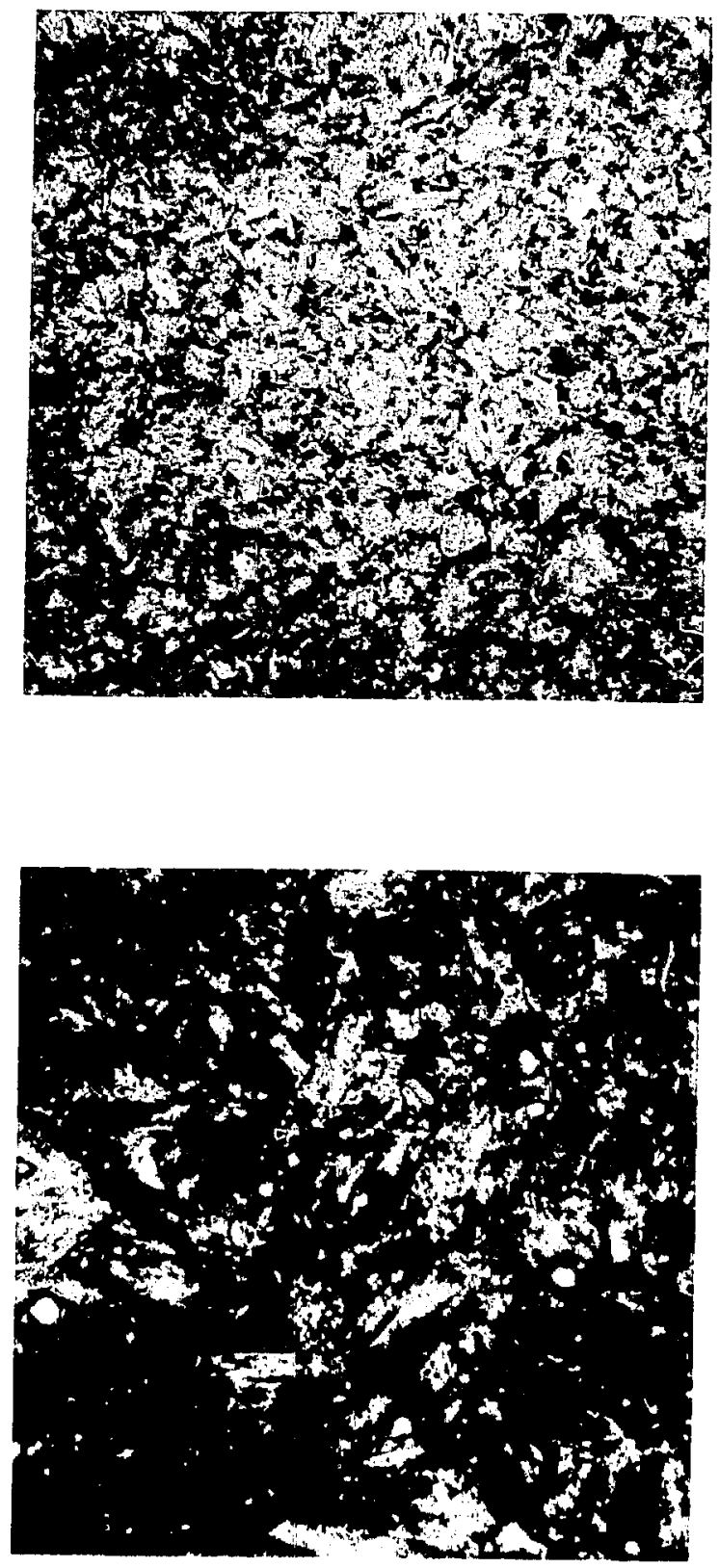

F1G. 56. Microstructure of TaC-C composite containing 14 wt\% $3.3 \mu \mathrm{m} \mathrm{TaC}-30$. (Conventional metallography. Top, 100X. Bottom, 500x.) 

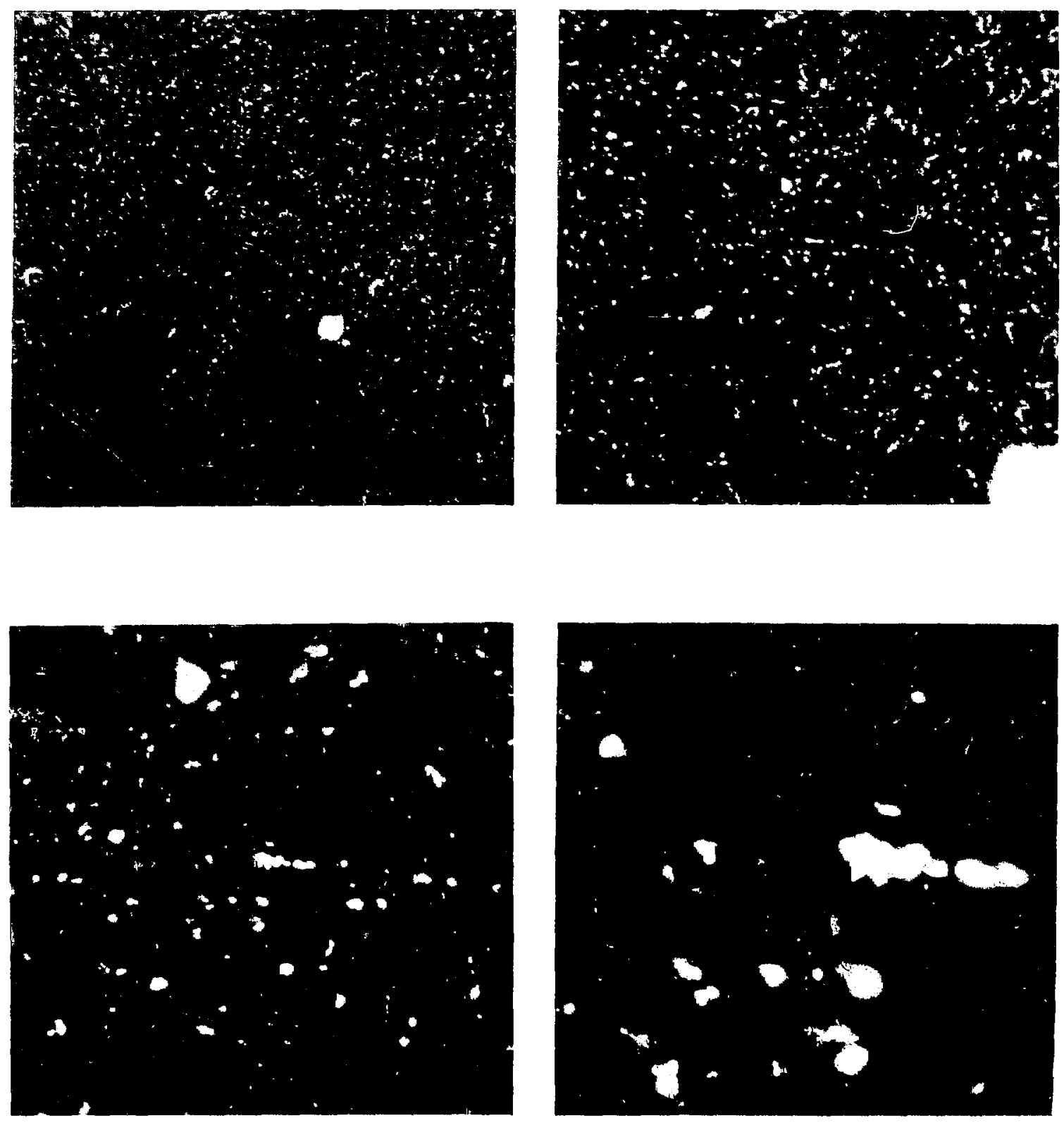

Fig. 57. Microstructure of TaC-C composite containing 14 wt $1.3 \mu \mathrm{m}$ TaC-30. (Scanning electron micrographs. Top left, 100x. Top right, 300x. Bottom left, 1000x. Bottom right, 3000x.) 

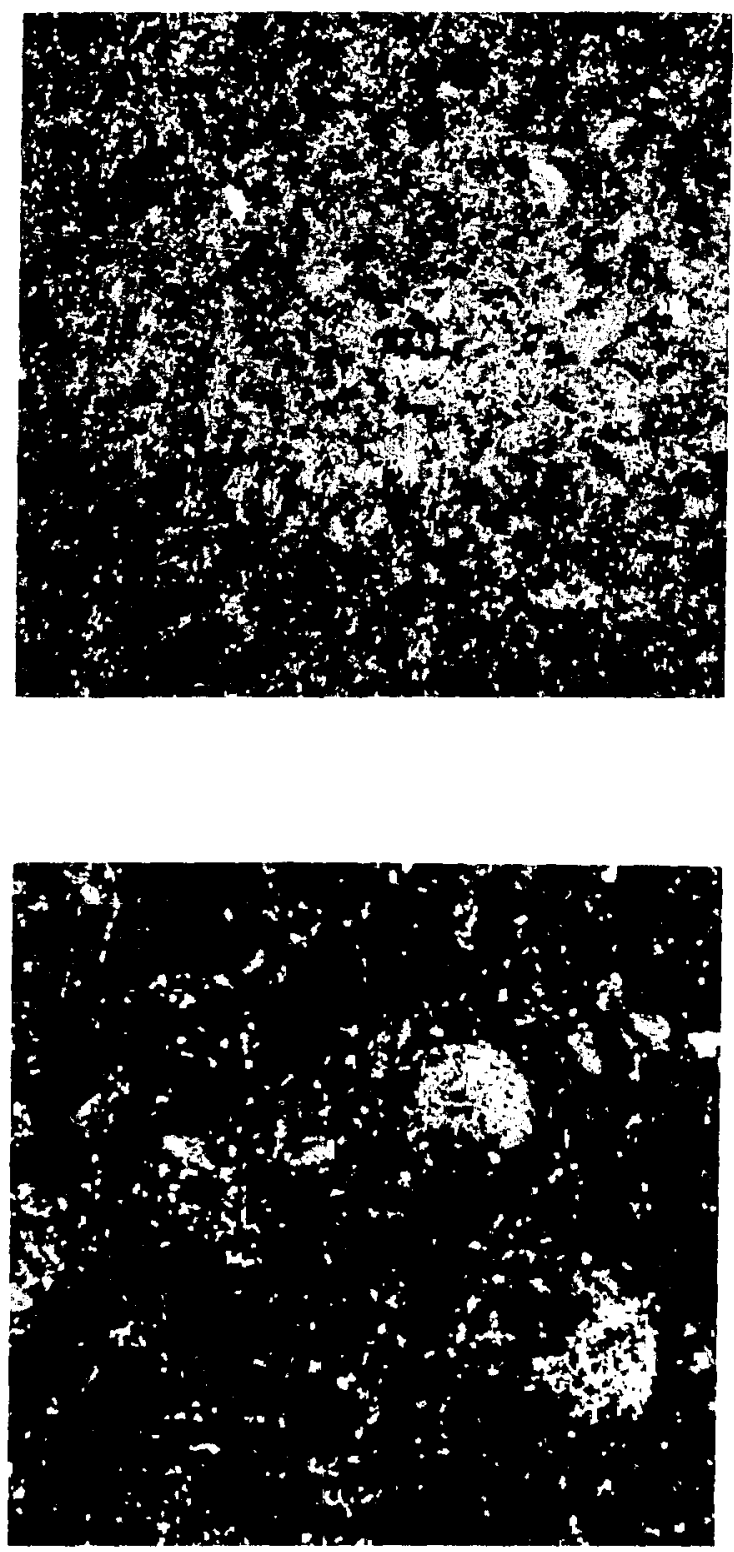

FIg. 58. Microetructure of TaC-C composite conteining 40 wt\$ $1.3 \mathrm{\mu m} \mathrm{TaC-30.} \mathrm{(Conventionel} \mathrm{metallography.}$ Top, 100X. Bottom, 500x.) 

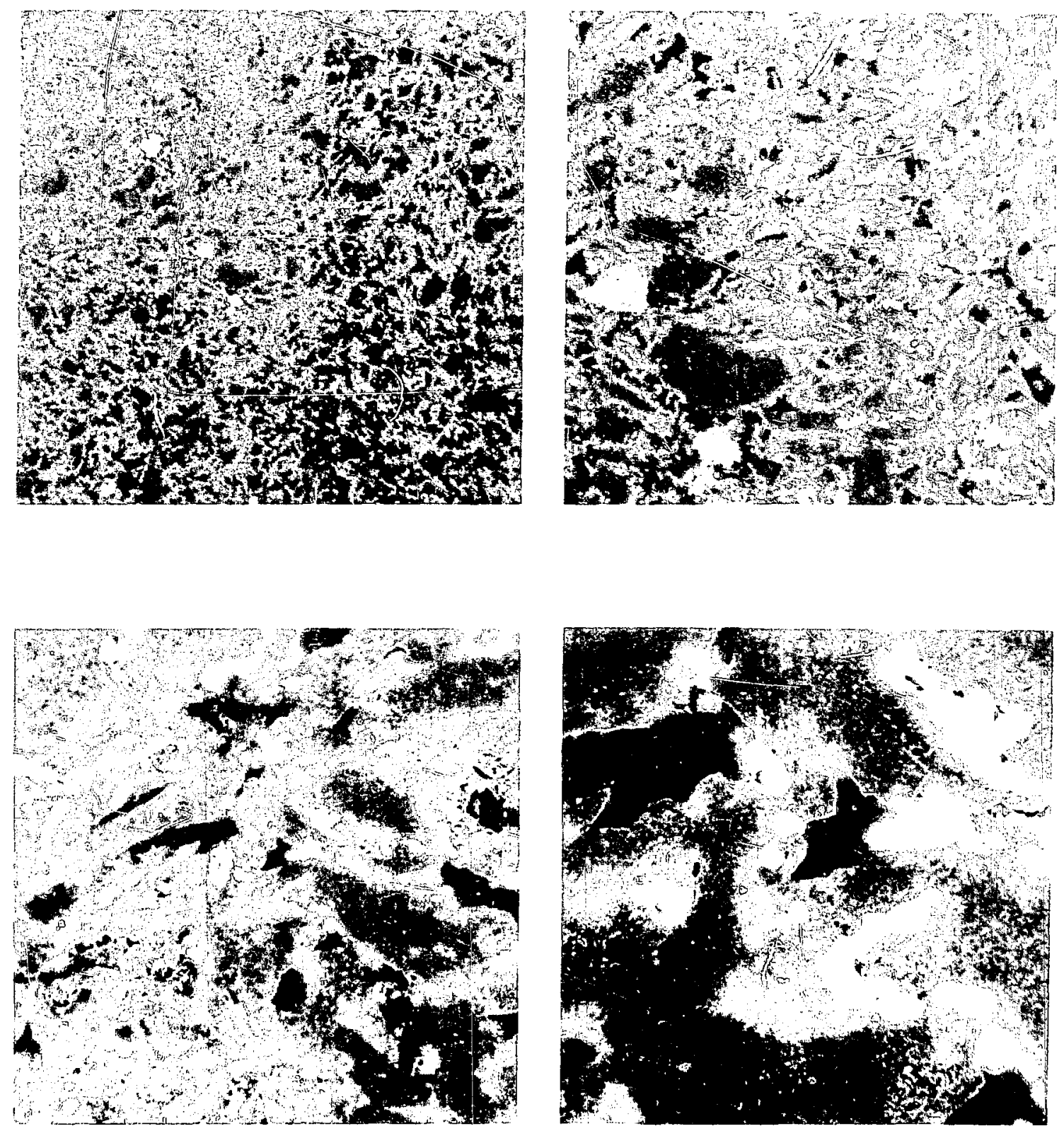

F1g. 59. M1crostructure of TaC-C composite containing 40 wt $1.3 \mu \mathrm{m} \mathrm{TaC-30.} \mathrm{(Scanning} \mathrm{electron} \mathrm{micrographs.}$ Top left, 100x. Top right, 300x. Bottom left, 1000x. Bottom right, 3000x.) 

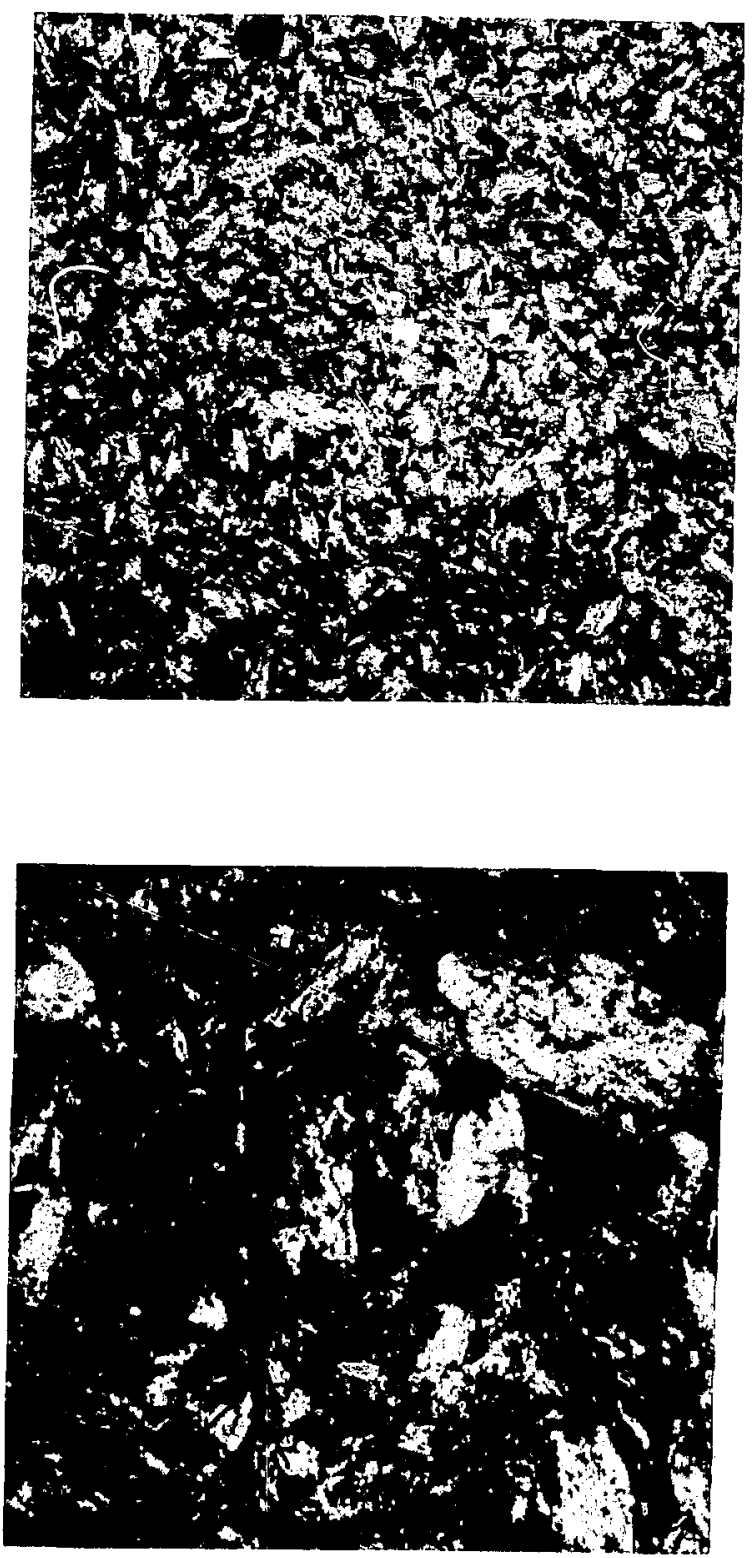
Fig. 60. Microstructure of TaC-C composite containing I wt to $40 \mu \mathrm{m}$ TaC-45. (Conventional metallography.
Top, 100X. Bottom, 500X.) 

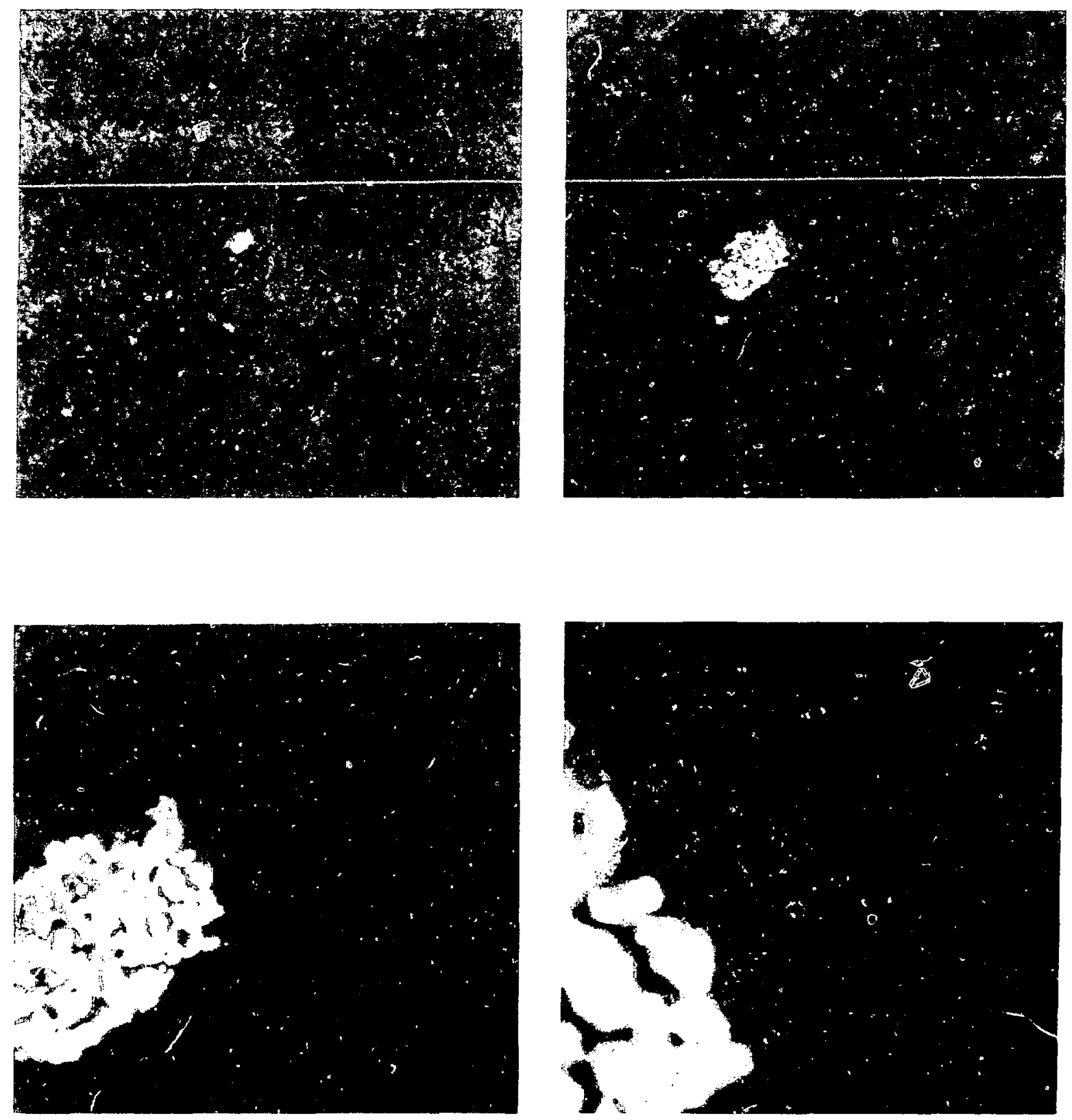

Fig. 61. Microstructure of TaC-C composite containing 1 wt\% nominal $40 \mu \mathrm{m}$ TaC-45. (Scanning electron micro. graphs. Top left, 100X. Top right, 300X. Bottom left, 1000X. Bottom right, 3000x.) 

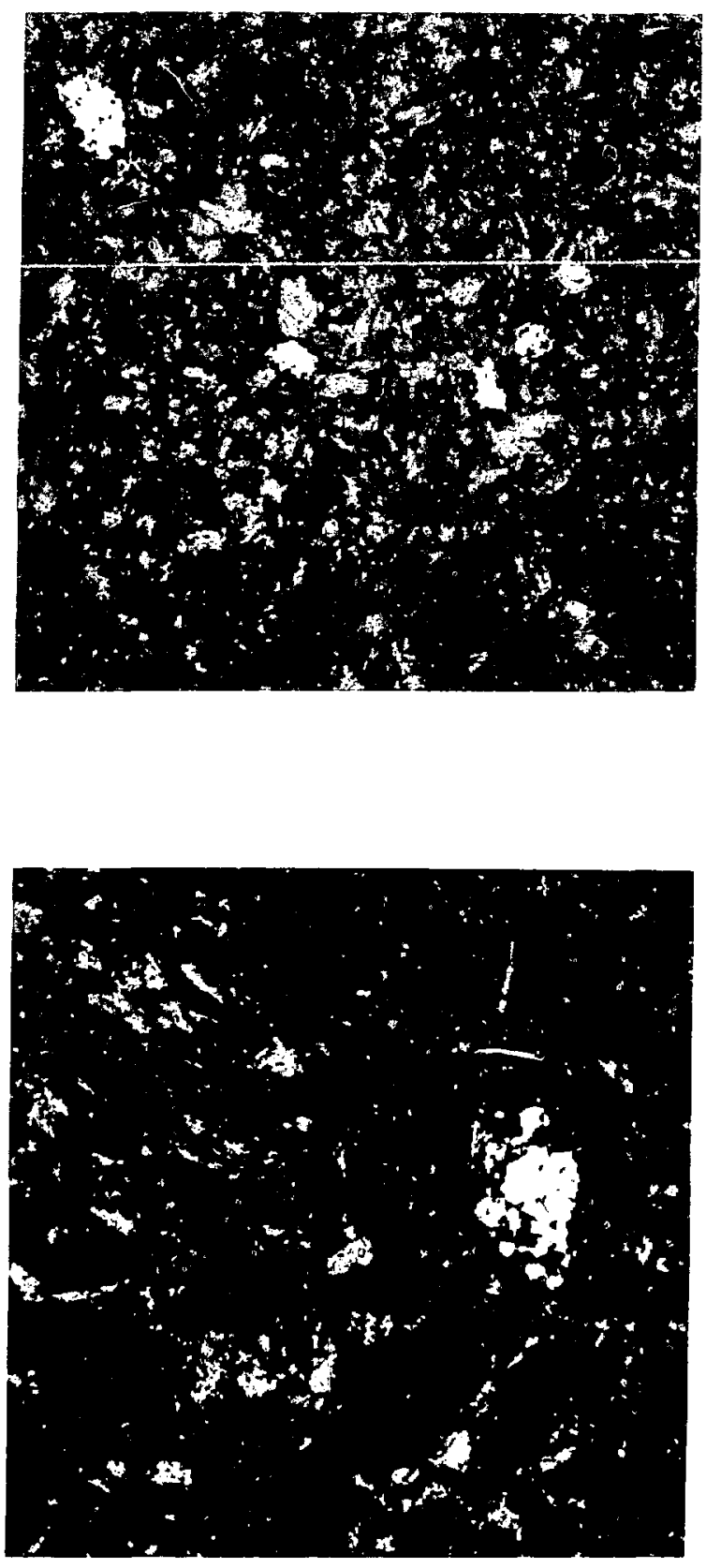

ig. 62. Microstructure of TaC-C composite containing 5 wt\% $40 \mathrm{~mm}$ TaC-45. (Conventional metallography. Top, 100X. Bottom, 500X.) 

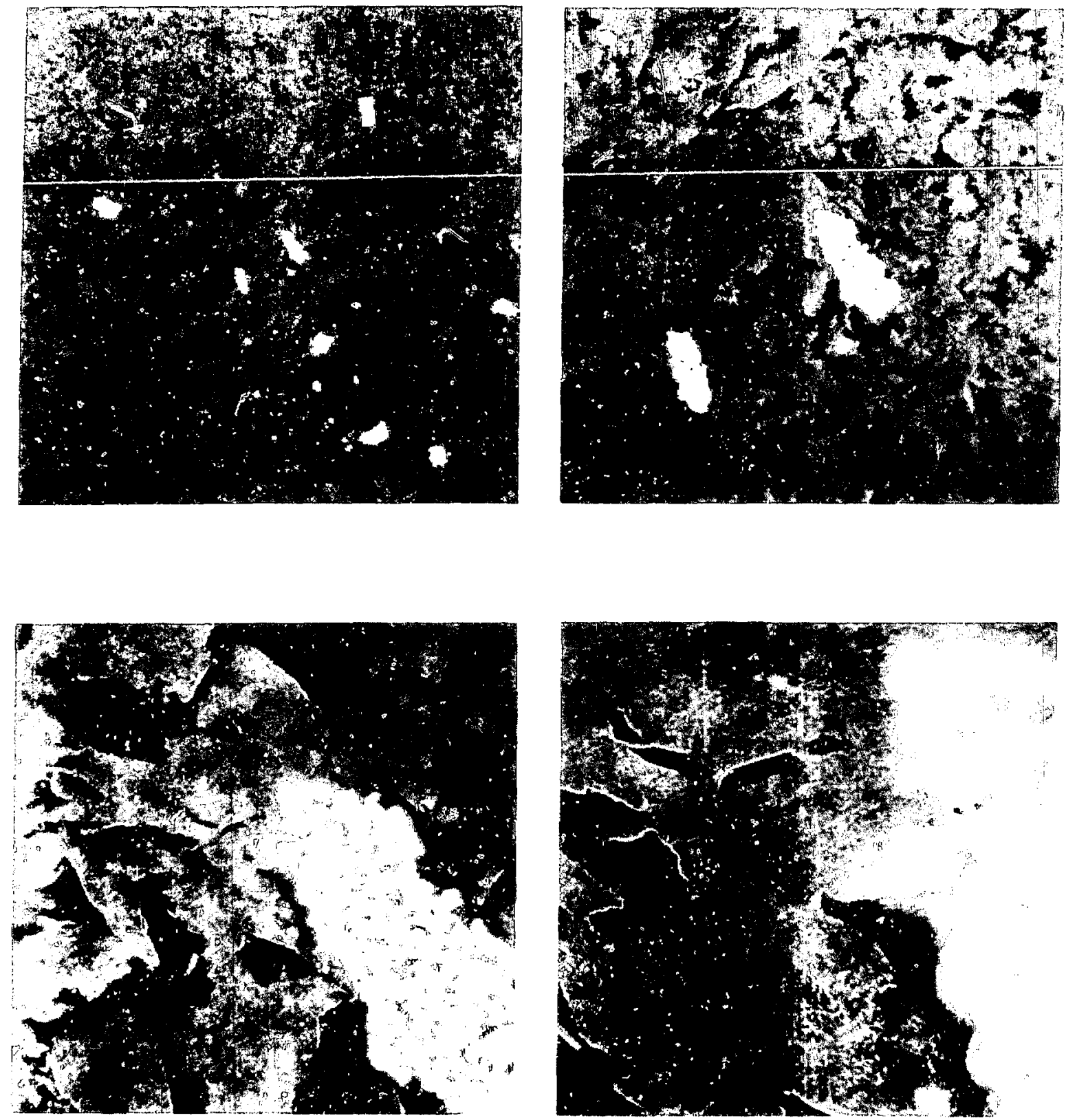

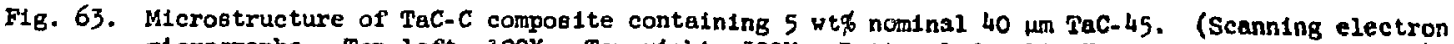
mlerographs. Top left, 100X. Top right, 300X. Botton left, $2000 \mathrm{x}$. Bottom right, 3000X.) 

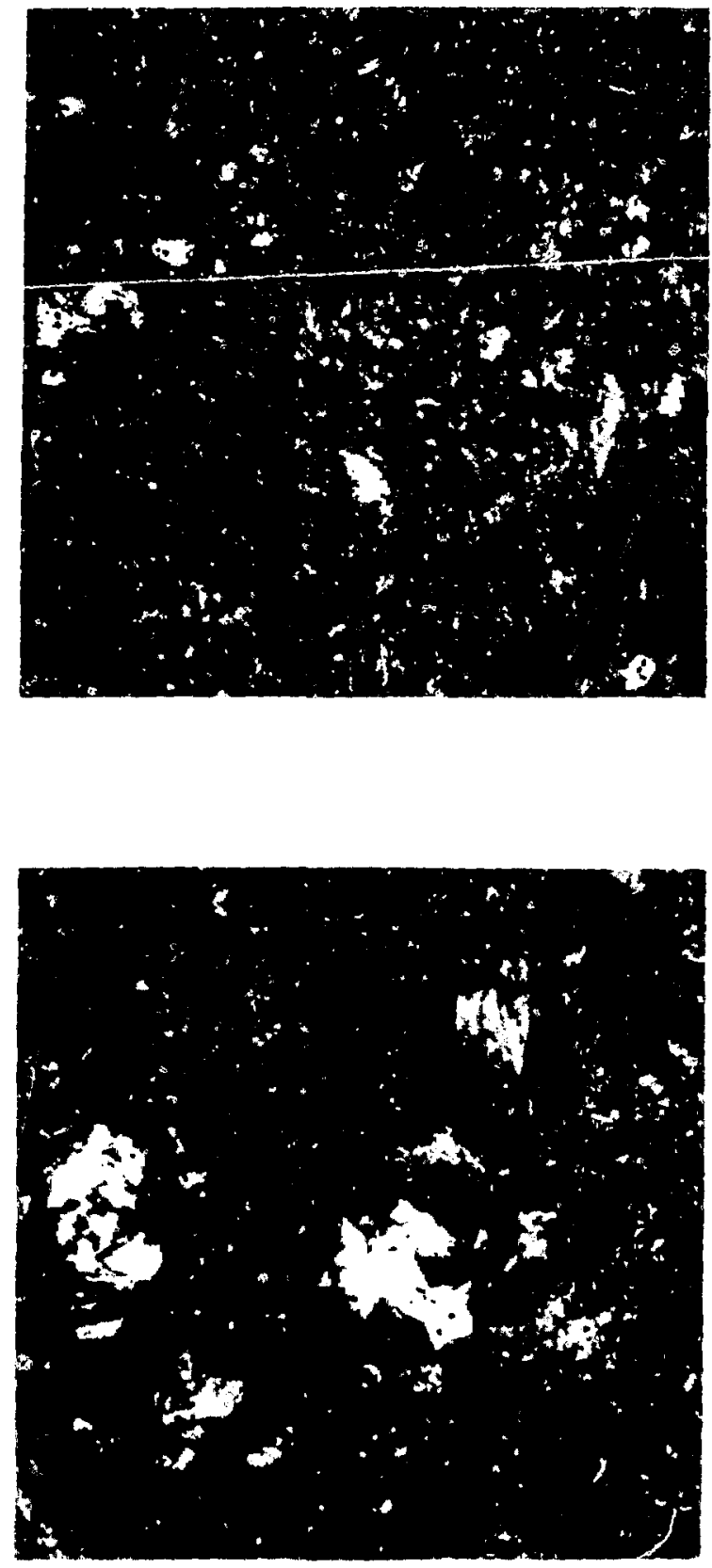

Fig. 6it. Micrsotrutiture of TaC-C composite containing 7 wtg ho um Tac-45. (Conventional metallography. Tep, 100x. Bottom, 500x.) 

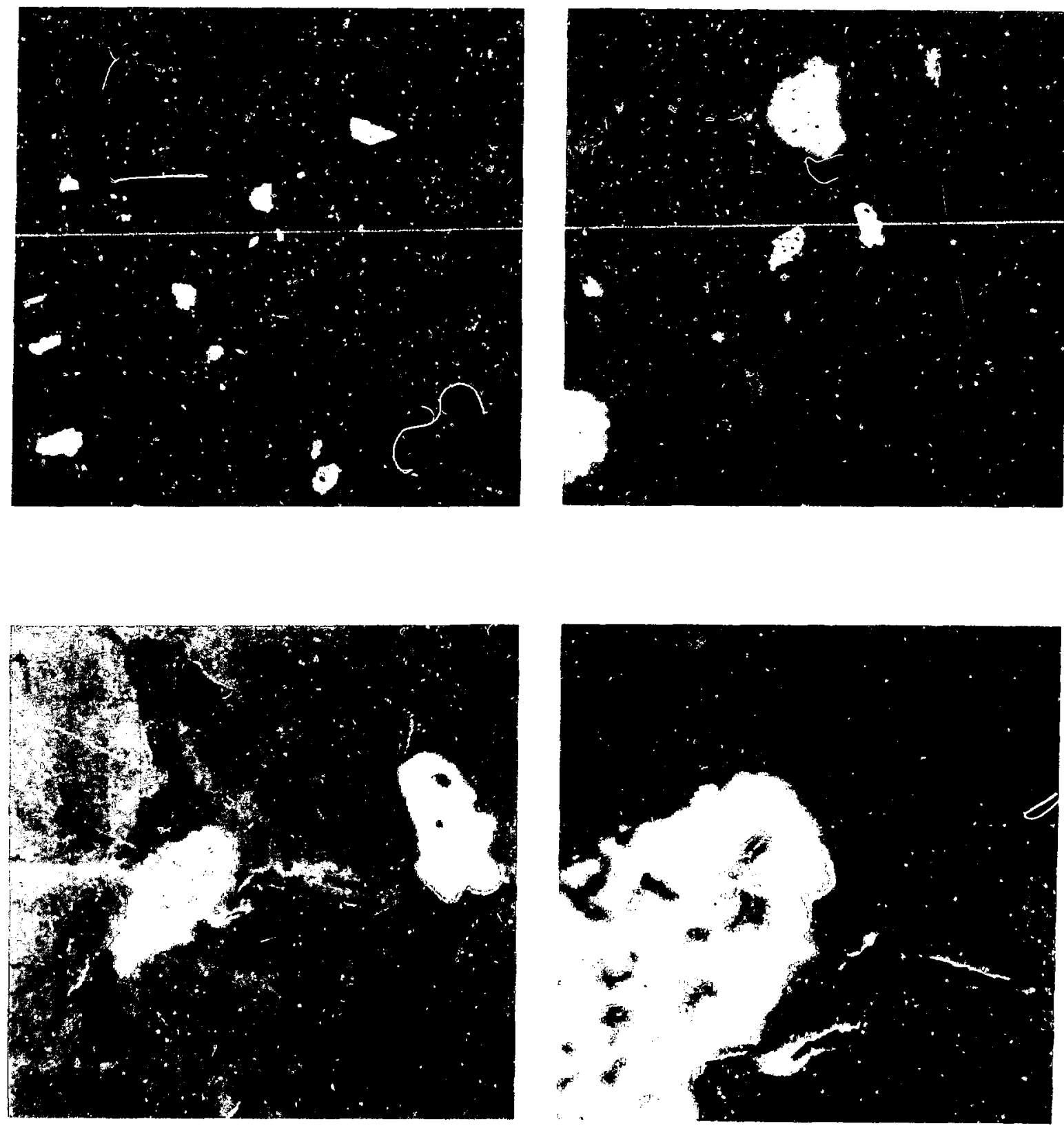

Fig. 65. Microstructure of TaC-C composite containing 7 wt\% nominal $40 \mu$ maC-45. (Scenning electron micrographs. Top left, 100X. Top right, 300x. Bottom left, 1000X. Bottom right, 3000X.) 

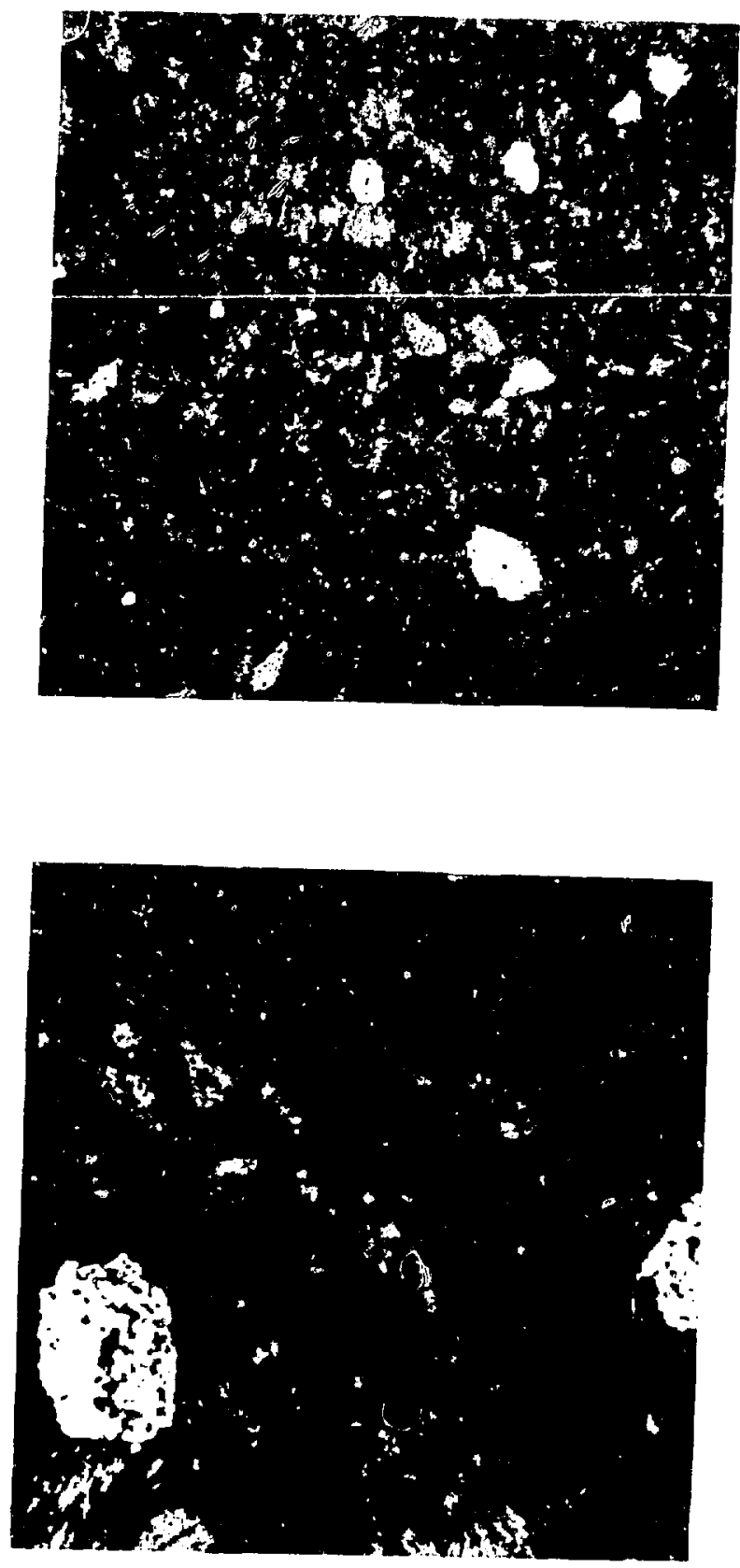

F1B. 66. Microstructure of TaC-C composite containing 14 wt\% $40 \mu \mathrm{m}$ TaC-45. (Conventional metallography.
Top, 100X. Bottom, 500x.) 

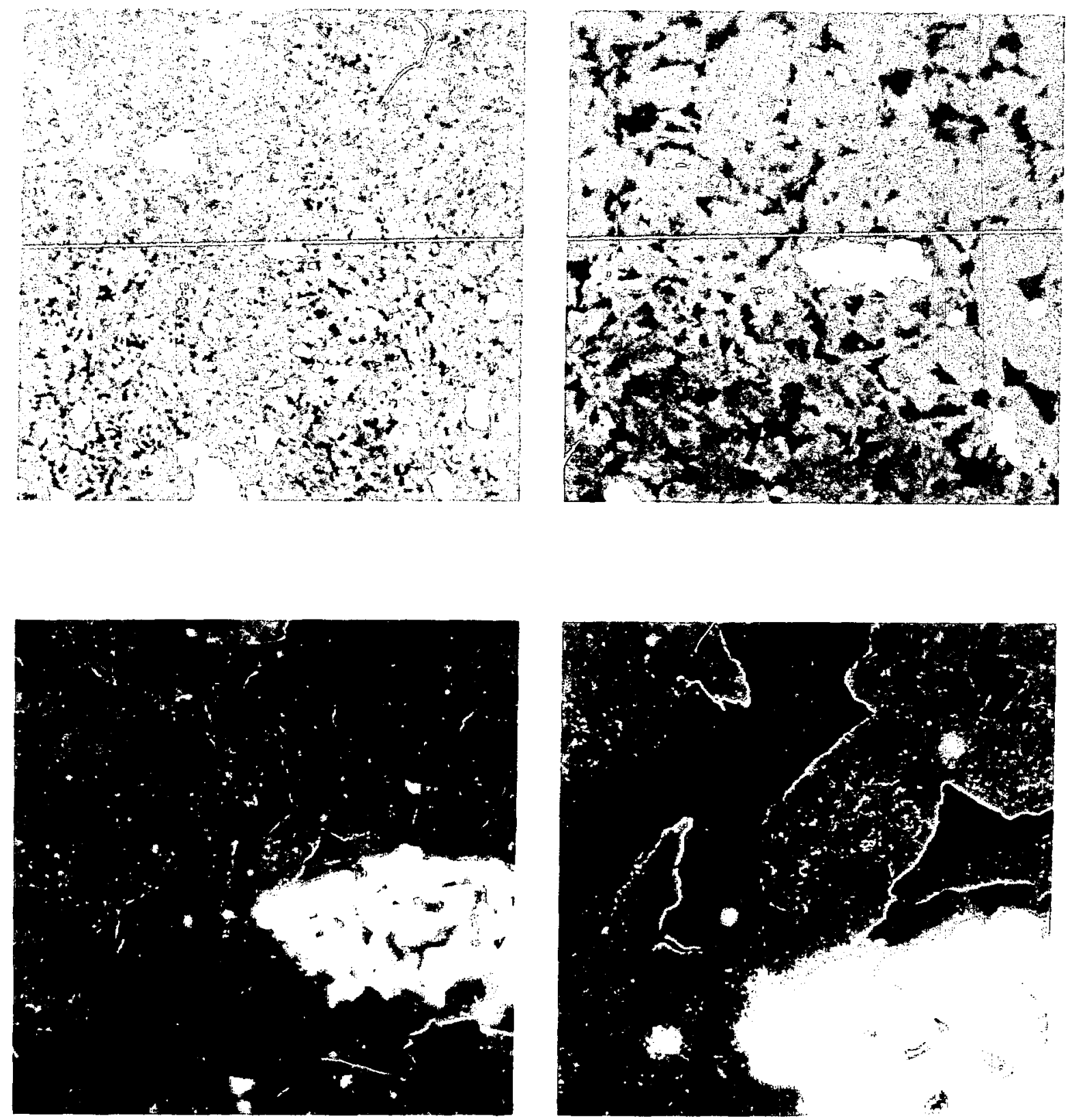

Fig. 67. Microstructure of TaC-C composite containing 14 wt 70 nominal $40 \mu \mathrm{m} \mathrm{TaC}-45$. (Scanning electron micrographs. Top left, 100X. Top right, 300X. Bottom left, 1000X. Bottom right, 3000X.) 

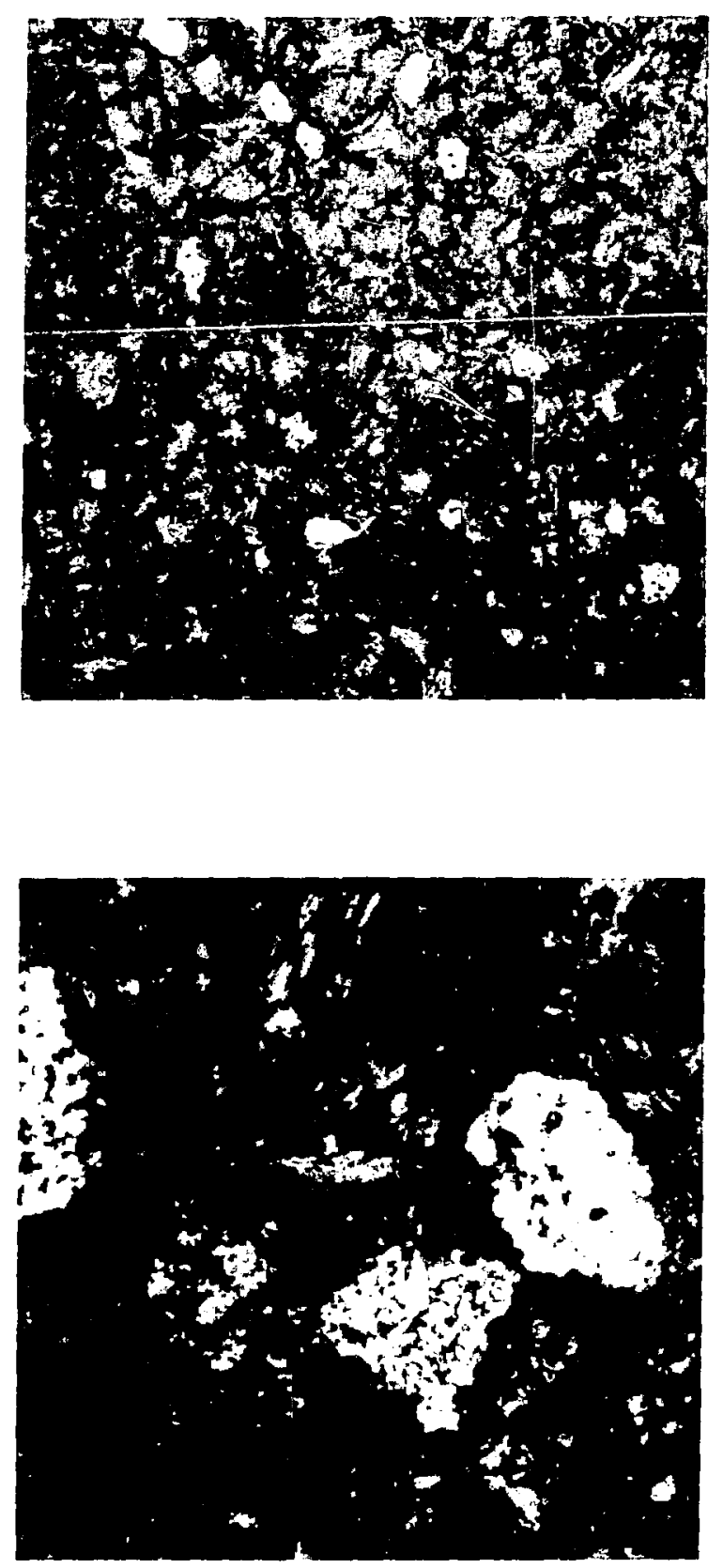

Fig. 68. Microstructure of TaC-C composite containing $20 \mathrm{wt} \% 40 \mu \mathrm{m}$ TaC-45. (Conventional metallography. Top, 100X. Botton:, 500X.) 

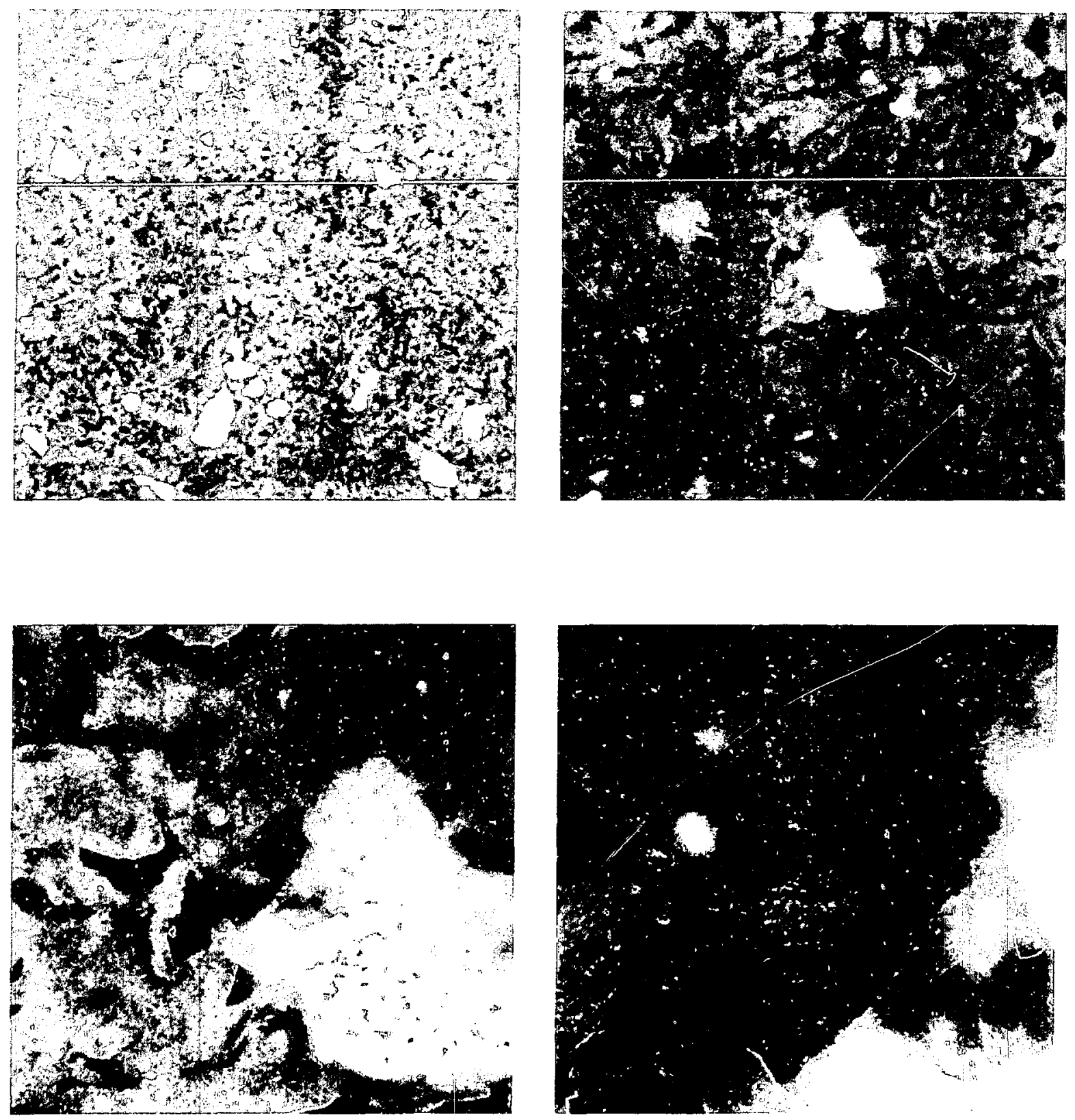

FIg. 69. Microstructure of TaC-C composite containing $20 \mathrm{wt}$ \% nominal $40 \mu \mathrm{m} \mathrm{TaC}-45$. (Scanning electron inicrographs. Top left, 100X. Top right, 300X. Bottom lef't, 1000X. Bottom right, 3000X.) 

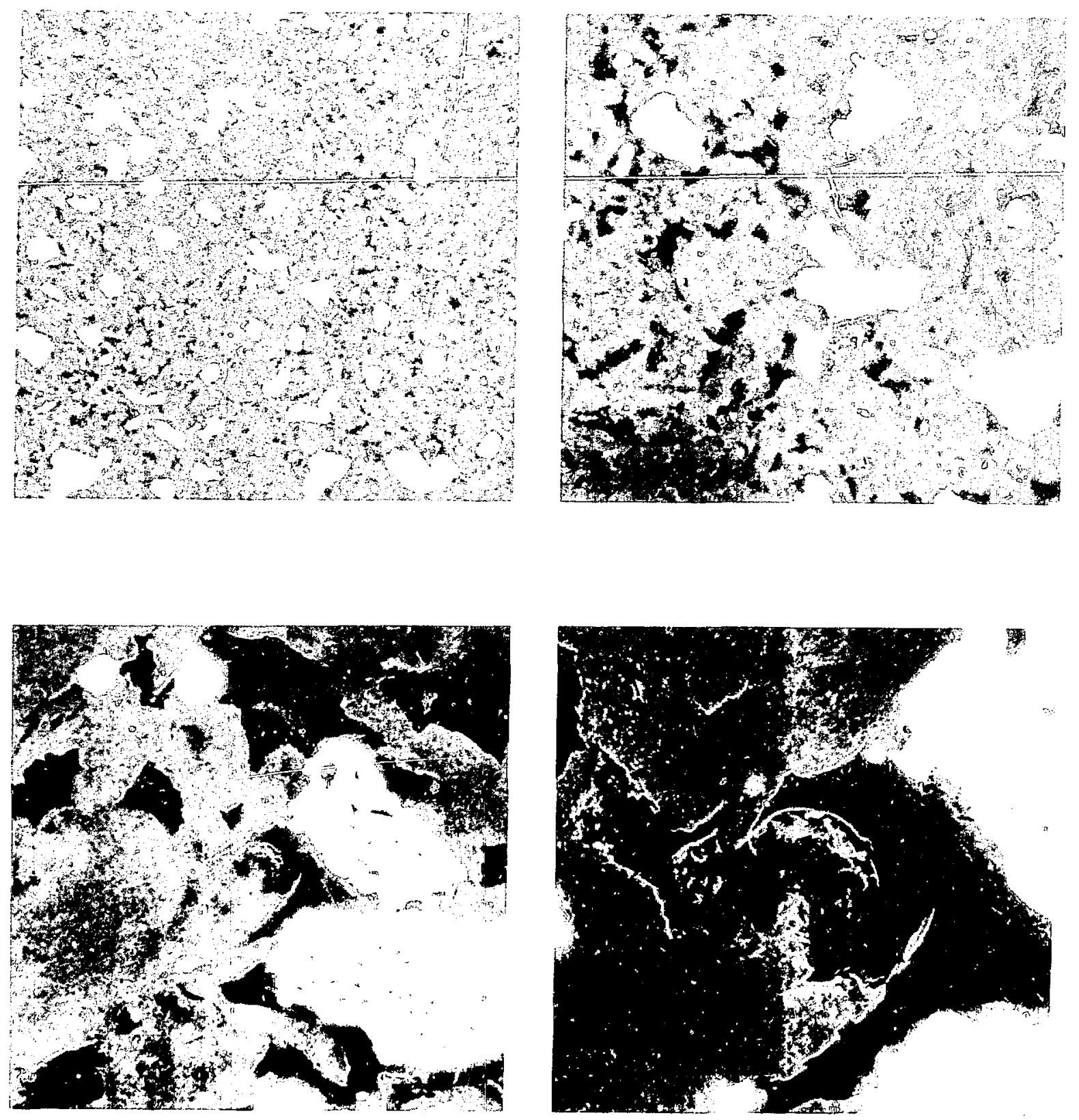

Fig. 7C. Microstructure of TaC-C composite containing $40 \mathrm{wt} \%$ nominal $10 \mu \mathrm{m}$ TaC-45. (Scanning electron micrographs. Top left, 100X. Top right, 300x. Bottom left, 1000x. Bottom right, 3000X.) 

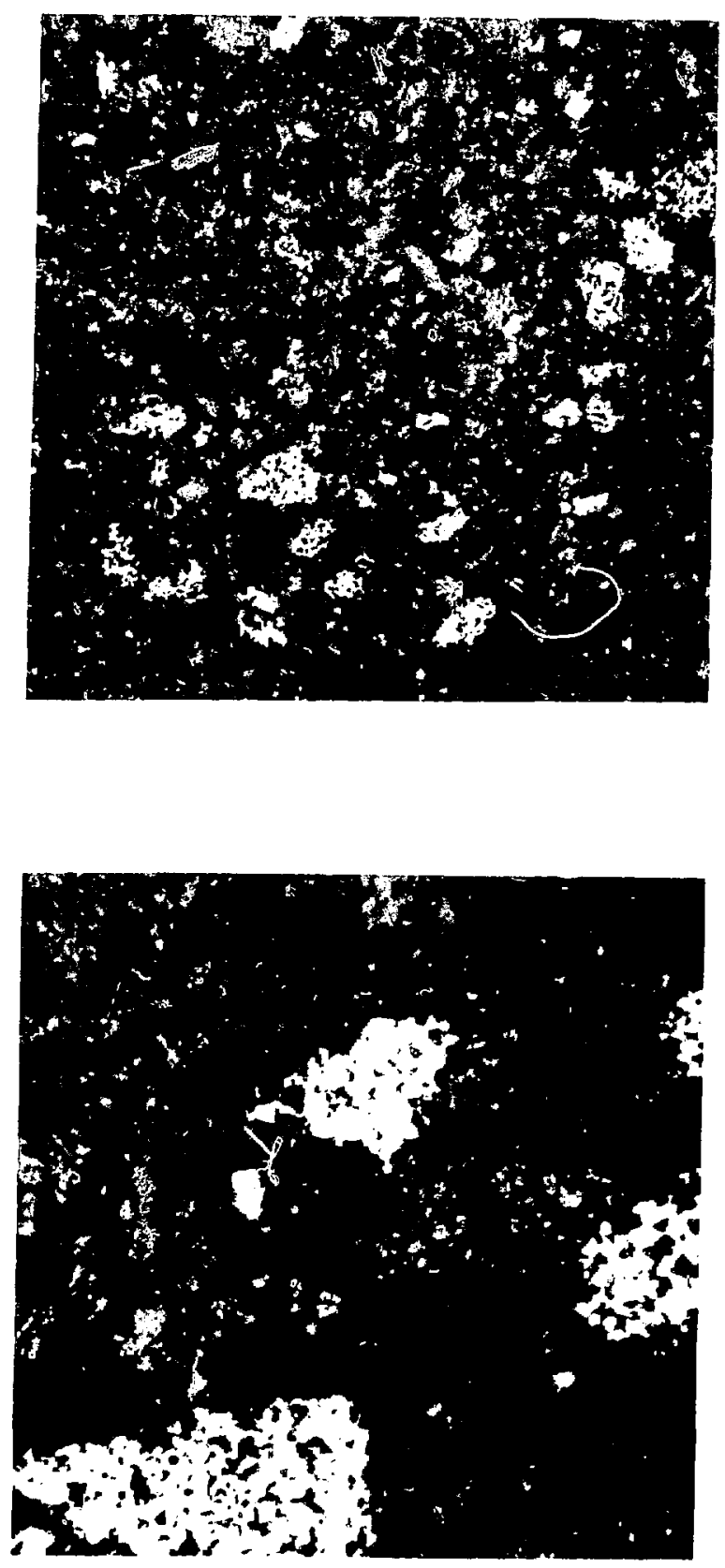
Fig. 71. Microstructure of TaC-C composite containiizg $40 \mathrm{wt} \% 40 \mathrm{~km}$ TaC-45. (Conventional metallography.
Top, 100X. Bottom, 500X.) 